\title{
From Fragment to Lead: A Structure-Guided Approach Towards a Selective FGFR2 Inhibitor
}

Lewis D. Turner ${ }^{\S}$, Chi H. Trinh ${ }^{\dagger}$, Ryan A. Hubball ${ }^{\S}$, Kyle M. Orritt ${ }^{\S}$, Chi-Chuan Lin ${ }^{\dagger}$, Julie E. Burns ${ }^{\ddagger}$, Margaret A. Knowles ${ }^{\ddagger}$, and Colin W. G. Fishwick ${ }^{\S *}$

${ }^{\S}$ School of Chemistry, University of Leeds, Leeds, LS2 9JT, U.K. 'Astbury Centre for Structural Molecular Biology, Institute of Molecular and Cellular Biology, University of Leeds, Leeds, LS2 9JT, UK. 'Leeds Institute of Medical Research at St James's, University of Leeds, Leeds, LS9 7TF, UK.

$\|$ Present address: Department of Chemistry, Scripps Research, 10550 N Torrey Pines Road, La Jolla, CA 92037, US.

*Corresponding author: c.w.g.fishwick@1eeds.ac.uk

\section{$\underline{\text { Abstract }}$}

Fibroblast growth factor receptors (FGFRs) are implicated in a range of cancers with several pan-kinase and selective-FGFR inhibitors currently being evaluated in clinical trials for FGFRimplicated malignancies. Pan-FGFR inhibitors often cause toxic side-effects via off-target inhibition and very few examples of subtype-selective inhibitors exist. Herein, we describe a structure-guided approach towards the development of a selective FGFR2 inhibitor. De novo design was carried out on an existing fragment series that exhibited moderate sub-micromolar activity against FGFRs 1-3. Subsequent synthesis, biological evaluation, and iterative rounds of SBDD led to an inhibitor with nM potency that exhibited moderate selectivity for FGFR2 over FGFR1/3. Subtle changes to the lead inhibitor resulted in a complete loss of selectivity for FGFR2. Subsequent X-ray crystallographic studies revealed significant morphological differences in the P-loop flanking the ATP-binding pocket which appeared to be determined by which inhibitor was bound. It was posited that this dynamic phenomenon was fundamental to the selectivity of these compounds and complementary to current theories surrounding sub-type FGFR2 selectivity. In addition, several derivatives exhibited low $\mu \mathrm{M}$ potency against FGFR1/2-activated cell lines and underlined the potential of these compounds for development into medicines for the treatment of FGFR-driven cancers.

\section{Introduction}

FGFRs are transmembrane receptor tyrosine kinases that transmit cellular signaling by binding FGFs. The four known FGFRs (FGFR1-4) are implicated in various cellular processes such as: development, tissue repair, and wound healing, ${ }^{1}$ and have been shown to play crucial roles in the formation of cancer. ${ }^{2-4}$ The general structure of all FGFRs is uniform, consisting of an extracellular binding domain, a single transmembrane domain, and an intracellular domain. ${ }^{1}$ Binding of an FGF to the extracellular domain causes receptor dimerisation and subsequent conformational changes which lead to order-specific transautophosphorylation of specific tyrosine residues within the intracellular 
kinase domain. ${ }^{5,6}$ FGFR signal transduction leads to activation of a plethora of cascade pathways including PI3K-PKB, RAS-MAPK, phospholipase $\mathrm{C}$ gamma $(\mathrm{PLC} \gamma$,$) and signal transducer and$ activator of transcription proteins (STAT). ${ }^{7}$

Aberrant signaling of FGFRs is implicated in a multitude of cancer types including bladder, endometrial, breast, and lung, with disease progression occurring through overexpression, point mutations, and/or chromosomal translocations. ${ }^{8-11}$ The advancement of small molecule therapeutics for FGFR-implicated malignancies has illuminated several pan-angiokinase and FGFR-selective inhibitors which have been extensively documented over the last few years (Figure 1). ${ }^{12-17}$
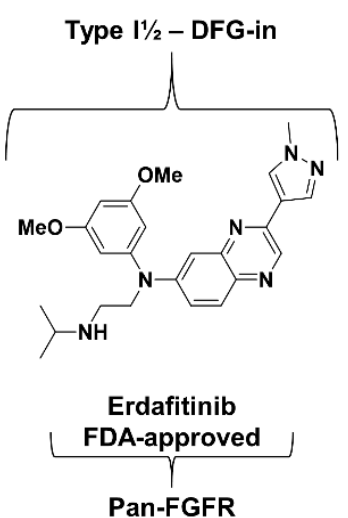
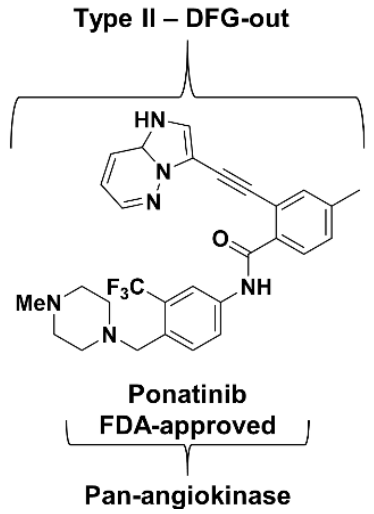
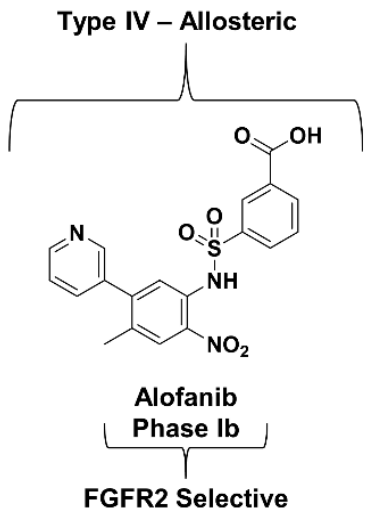

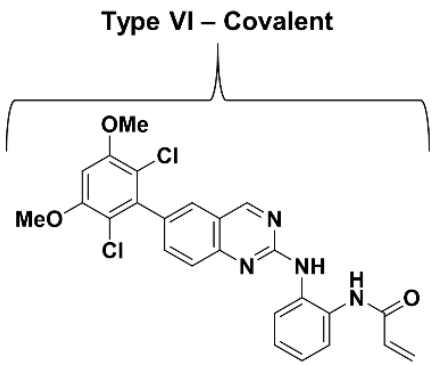

BLU9931

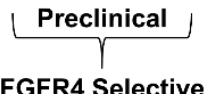

Figure 1: Examples of Type I⿳亠丷厂, II, IV and VI small molecule kinase inhibitors currently approved or in development for FGFR-implicated malignancies.

Kinase inhibitors are classified into seven distinct categories (Type I, I 1², II, III, IV, V, and VI) which is determined by their modes of inhibition. ${ }^{18}$ Type I and $\mathrm{I} 1 / 2$ inhibitors occupy the ATP-binding site with the Asp-Phe-Gly (DFG) motif, a conserved region of the activation loop, exhibiting an 'in' conformation (Figure S1A), with Type I and I $1 \frac{2}{2}$ inhibitors targeting the active and inactive forms of the kinase, respectively. Erdafitinib, a Type I⿳1/2 inhibitor, was approved in the US in 2019 for the treatment of locally advanced or metastatic FGFR2/3-driven urothelial carcinoma and is currently under investigation for a range of other FGFR-implicated cancers. ${ }^{19}$ Type II inhibitors bind within the ATP binding pocket with a 'DFG-out' conformation (Figure S1B) and solely bind the inactive form of the kinase. These inhibitors offer an advantage over Type I inhibitors in that their binding modes are noncompetitive with ATP and may overcome issues of selectivity arising from the structural similarities of kinase ATP binding pockets. ${ }^{20}$ Ponatinib is a Type II inhibitor and gained accelerated FDA-approval for the rare disease chronic myeloid leukaemia in 2012, where resistance or intolerance to at least two other kinase inhibitors was implicated. ${ }^{21}$ Type III and IV inhibitors are allosteric in nature, with Type III inhibitors binding next to the ATP-binding pocket and Type IV inhibitors binding to other areas of the enzyme. ${ }^{18}$ Alofanib is a selective, FGFR2 Type IV inhibitor and binds to the extracellular domain of the kinase, disrupting signal transduction through prevention of FGF binding. ${ }^{22}$ It is has been shown to have anti-tumour effects in preclinical ovarian cancer models and is currently being evaluated in Phase $\mathrm{Ib}$ for patients with metastatic gastric cancer. ${ }^{23}{ }^{24}$ Type $\mathrm{V}$ inhibitors are single entity, bivalent 
molecules that bind two distinct sites of the kinase simultaneously e.g. the ATP-binding pocket and an allosteric site joined by a linker. ${ }^{18}$ Currently, no examples of FGFR inhibitors possess this type of inhibition but this approach has been used for other kinases such as Src and Abl. ${ }^{25-27}$ Type I-V are all reversible in nature, whereas the remaining category, Type VI, represents inhibitors with covalent modification potential. ${ }^{18}$ The kinase domain of FGFR1-4 contains several conserved cysteine residues (Figure S2). Cys486 (in FGFR1), has been the target of several irreversible modifier campaigns owing to its close proximity to the ATP-binding pocket. ${ }^{28-30}$ FGFR4 possesses a non-conserved cysteine (Cys552) at the entrance of the ATP-binding pocket and has also allowed the development of selective FGFR4 irreversible inhibitors (Figure S1C). ${ }^{31,32}$ BLU9931 was one of the first selective irreversible FGFR4 inhibitors and possesses exquisite selectivity; it is currently under investigation for the treatment of hepatocellular carcinomas. ${ }^{33}$

Although desired through their ability to treat various FGFR malignancies, pan-FGFR inhibitors often exhibit 'FGFR1-specific' toxicity profiles that lead to adverse side-effects, such as hyperphosphatemia and tissue mineralization, believed to stem from abnormal signalling of FGF23. ${ }^{34}$ The development of exquisitely selective FGFR sub-type inhibitors remains heavily biased toward FGFR4, through means outlined vide supra, as the high sequence homology (Table S1) of the FGFR13 kinase domains, particularly the active site residues, has made it very difficult to develop Type I, I⿳亠丷, , or II sub-type selective inhibitors. Of particular importance is the development of FGFR2 sub-type selective inhibitors. Several studies have outlined the role of FGFR2 as an oncogenic driver in cholangiocarcinoma, a rare form of cancer that is difficult to diagnose and affects $\sim 8000$ people in the US each year. ${ }^{35-37}$ FGFR2 has also been shown to play a role in promoting acquired resistance of human epidermal growth factor receptor two (HER2)-targeted treatments via indirect overactivation of FGFR2 from tumour-associated fibroblasts. ${ }^{38} \mathrm{~A}$ recent breakthrough announced by Casaletto and co-workers has outlined the development of RLY-4008 (structure not publicly disclosed), an exquisitely selective FGFR2 inhibitor that possesses over 200-fold preference for FGFR2 over FGFR1. ${ }^{39}$ These researchers reported that no structural differences in the X-ray co-crystal structures of RLY-4008 bound within FGFR1/2 were observed, however, molecular dynamic simulations revealed potential differences in a flexible loop region between FGFR1/2 and this was posited to be the source of the exquisite selectivity of this compound. ${ }^{40}$ RLY-4008 is currently under Phase 1 clinical evaluation for FGFR2-implicated intrahepatic cholangiocarcinoma or other advanced solid tumours. ${ }^{41}$ The acute lack of FGFR2 sub-type selective inhibitors, coupled with the necessity to abrogate pan-FGFR inhibitor toxicity issues and FGFR-specific malignancies, warrants further research into the development of such inhibitors. Herein, we describe a structure-guide approach towards an FGFR2 sub-type selective inhibitor. 


\section{Results and Discussion}

Our previous work outlined the identification of an indazole-based FGFR fragment inhibitor series that exhibited moderate activity against FGFR1-3. ${ }^{42}$ Hit identification for this particular series was carried out using SPROUT, a de novo design software developed in the early 90s at The University of Leeds. ${ }^{43}, 44$ Development of this series was also aided by the use of molecular modelling software Glide. ${ }^{45}$ This method of inhibitor design was further incorporated within this project to design larger compounds predicted to inhibit FGFR1. Existing potent indazole-based inhibitors of FGFR kinases possess chemical functionality emanating from the 3-position of the indazole ring which, when bound to the FGFR kinase, has been shown to extend toward the solvent exposed region of the binding cavity. ${ }^{46-48}$ We employed this approach, and modelled molecular extensions from the indazole-3position which could also target Ser565 as a potential H-bonding contact (Figure 2A/B).

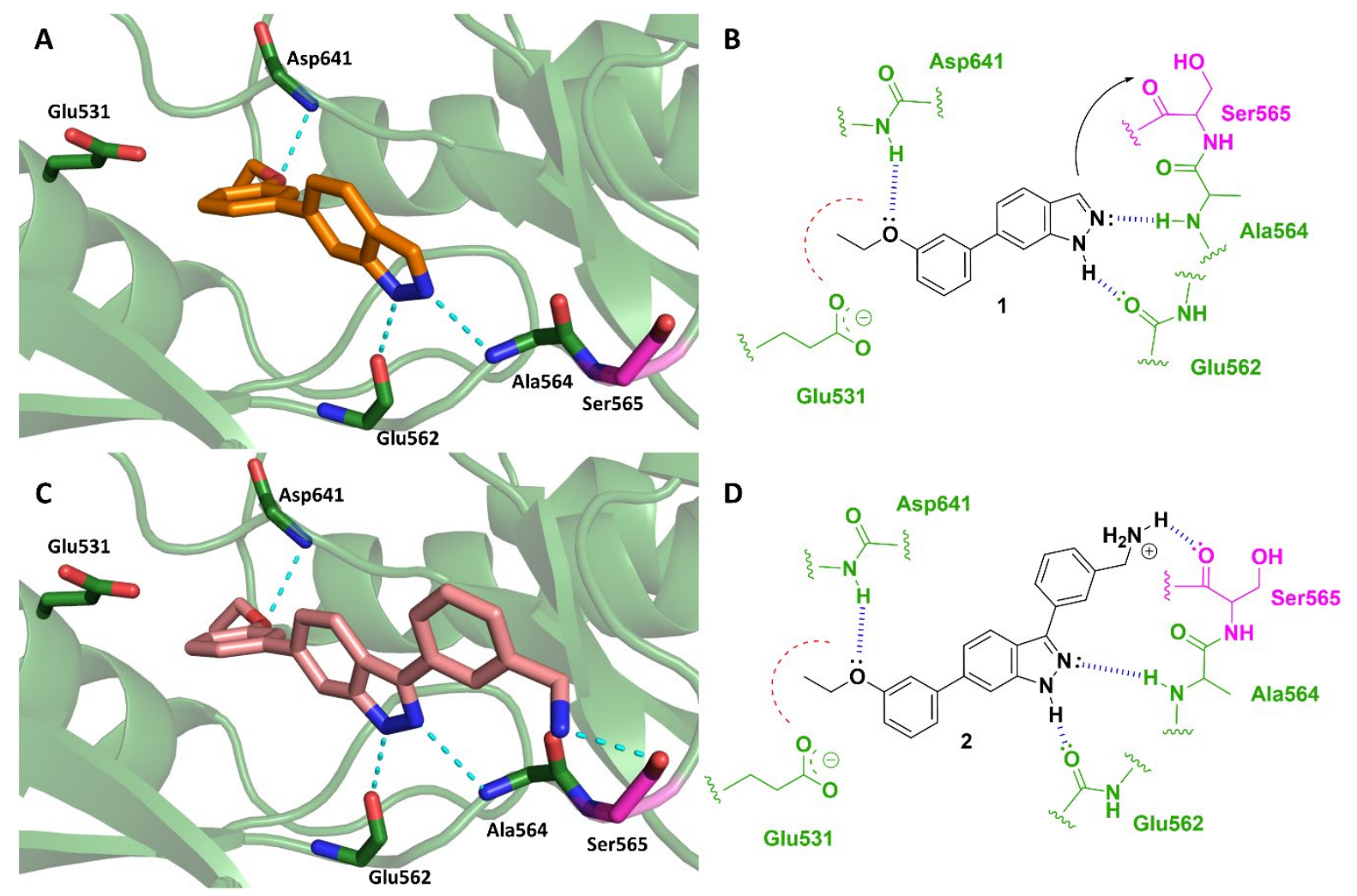

Figure 2: (A) Glide docking model of 1 (orange) bound within the FGFR1 active site. Predicted Hbonds are outlined by cyan hashed lines. (B) 2D representation of predicted binding mode of $\mathbf{1}$ bound within the FGFR1 active site. Hydrophobic pocket outlined by hashed red arc. Fragment growth can be carried at by extension at the 3-position toward Ser565. (C) Glide docking model of de novo designed compound 2 (pink). A new H-bond was predicted between the benzylamine and the backbone carbonyl of Ser565. (D) 2D representation of predicted binding mode of 2 bound within FGFR1. De novo design and docking models were carried out using the FGFR1/CH5183284 co-crystal structure (PDB 5B7V). ${ }^{49}$ 
Compound 1, the most potent fragment $\left(\mathrm{IC}_{50}=0.8 \mu \mathrm{M}\right.$ against FGFR2) identified previously ${ }^{42}$, was chosen as the template compound for de novo design using SPROUT. Appropriate target and spacer templates were chosen using the modules available in SPROUT ${ }^{43}$ and the resulting solutions triaged in terms of docking score and synthetic tractability. Compound 2, a benzylamine-based extension of the indazole core was predicted to form an H-bond with the backbone carbonyl of Ser565 (Figure 2C/D) and was chosen as our initial target compound. To validate the existence of the new predicted H-bond with Ser565, we included the hydroxymethyl and ethyl analogues (Figure 3) to act as controls through their differing or absent $\mathrm{H}$-bonding potential, respectively.
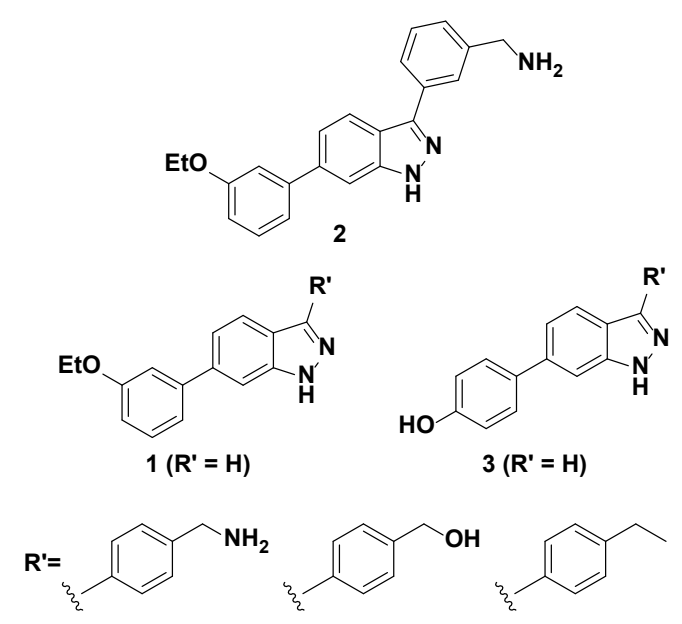

Figure 3: Focus library of extended versions of fragments.

Compound 3, a phenol-based fragment that exhibited similar potency $\left(\mathrm{IC}_{50}=3.0 \mu \mathrm{M}\right.$ against FGFR2) to 1 and slight FGFR2 selectivity (4-fold) over FGFR1 was also included. Compound $\mathbf{3}$ was predicted to form an $\mathrm{H}$-bond between the phenol $\mathrm{OH}$ and Glu531 deep within the ATP binding pocket. ${ }^{42}$ Several other ethoxy-fluoro-containing fragments were synthesised (Scheme S1) and biologically evaluated (Table S2), details pertaining to these derivatives can be found in the Supporting Information. Synthesis of the 'extended' ethoxy compounds began with a selective bromination at the 3-position of 6-iodoindazole (4) using NBS to give di-halogenated indazole 5 in an excellent yield (Scheme 1). Ethoxy derivatives were synthesised via selective Suzuki microwave (MW)-assisted chemistry with $\mathbf{5}$ 
to give brominated intermediate 6. Formation of small amounts of the bis-arylated product (9) was observed and provided an additional compound for biological evaluation.

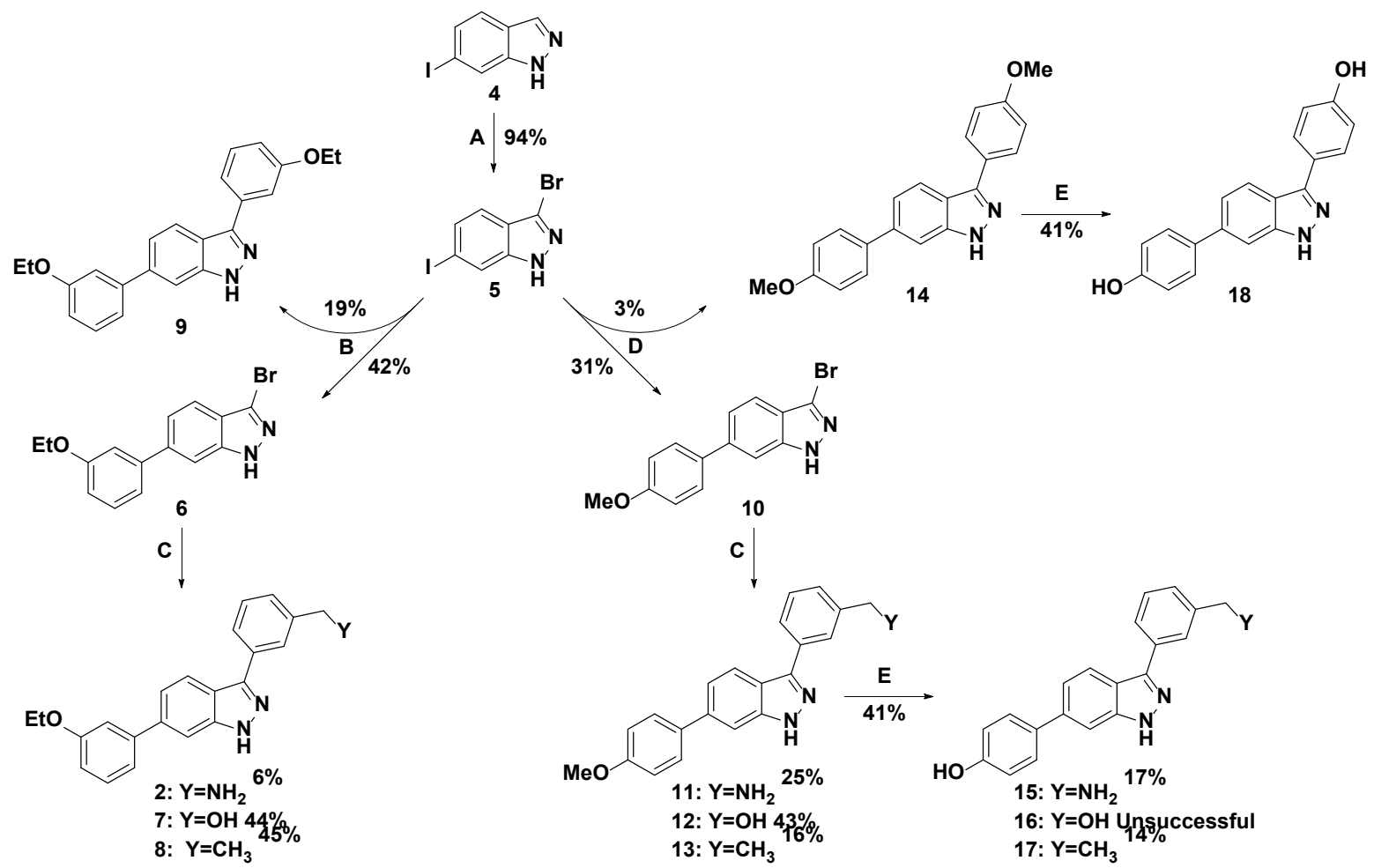

Scheme 1: Synthetic route to extended ethoxy- and phenol-based compounds. Reagents and conditions: (A) NBS, DMF, 2 h. (B) 3-ethoxyphenylboronic acid, $\mathrm{Pd}(\mathrm{dppf}) \mathrm{Cl}_{2}$ ), $\mathrm{Na}_{2} \mathrm{CO}_{3}$, dioxane: $\mathrm{H}_{2} \mathrm{O}, 110{ }^{\circ} \mathrm{C}$ MW, 2 h. (C) 3-methylamino/3-methylhydroxy/3ethyl-phenylboronic acid, Suzuki conditions. (D) 4methoxyphenylboronic acid, Suzuki conditions. (E) $\mathrm{BBr}_{3}, \mathrm{DCM}, 1 \mathrm{~h}$.

Intermediate $\mathbf{6}$ then underwent a final Suzuki coupling to yield 2, 7 and 8, respectively. Synthesis of the phenol-based target compounds (15-17) proceeded in a similar fashion but required protection of the phenol moiety as the methoxy ether. This was easily dealkylated to reveal the phenol at the end of the synthesis using $\mathrm{BBr}_{3}$. Attempts at using the unprotected phenol-based boronic acid were unsuccessful due to the rapid protodeboronation of ortho/para substituted phenolboronic acids. ${ }^{50}$ Direct formation of 16 from 12 resulted in an Appel-like reaction with the methoxy group being converted to the alkyl bromide. This intermediate was subsequently transformed into the alcohol using harsh basic conditions (Scheme S2). Bis-arylated phenol 14 was also formed as a side-product in the initial Suzuki coupling and was subsequently deprotected to yield 18 which was also evaluated for FGFR1-3 inhibition.

Compounds were screened against FGFR1-3 (Table 1) using a FRET-based assay. ${ }^{51}$ Unfortunately, 2 was inactive against FGFR1 and exhibited similar potencies as observed for fragment 1 against FGFR2/3. This suggested that the predicted H-bond between the protonated benzylamine and the Ser565 backbone carbonyl was unlikely to be occurring. Compounds 7-9 were also inactive. In contrast to 2, phenol 15 exhibited a $\sim 4$-fold and $\sim 5$-fold increase in potency against FGFR1/2 and 
FGFR3, respectively, when compared to fragment 3. Hydroxyethyl-containing $\mathbf{1 6}$ was also equipotent against FGFR1 with ethyl-containing $\mathbf{1 7}$ displaying a slight drop in potency in comparison to $\mathbf{1 5}$ and 16. This suggested the presence of H-bonding moieties in this area of the binding site is beneficial to potency. This may occur through direct H-bonding with proximal protein residues and/or via improved solvation, a likely scenario considering the proximity of this region to the solvent. Surprisingly, bisphenol 18, which was isolated as a side-product during the first Suzuki coupling (Scheme 1), exhibited an $\mathrm{IC}_{50}$ of $0.25 \mu \mathrm{M}$ against FGFR2, displaying a 2-fold increase in selectivity for FGFR2 over FGFR1 when compared to fragment 3 and benzylamine 15. In addition to understanding why de novo-designed target compound $\mathbf{2}$ did not yield the expected results, we also wanted to further explore the potential for improving FGFR2 selectivity.

Table 1: Summary of the biological activities of compounds 1-3, 7-9, 15-18 against FGFR1-3.

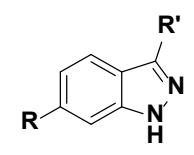

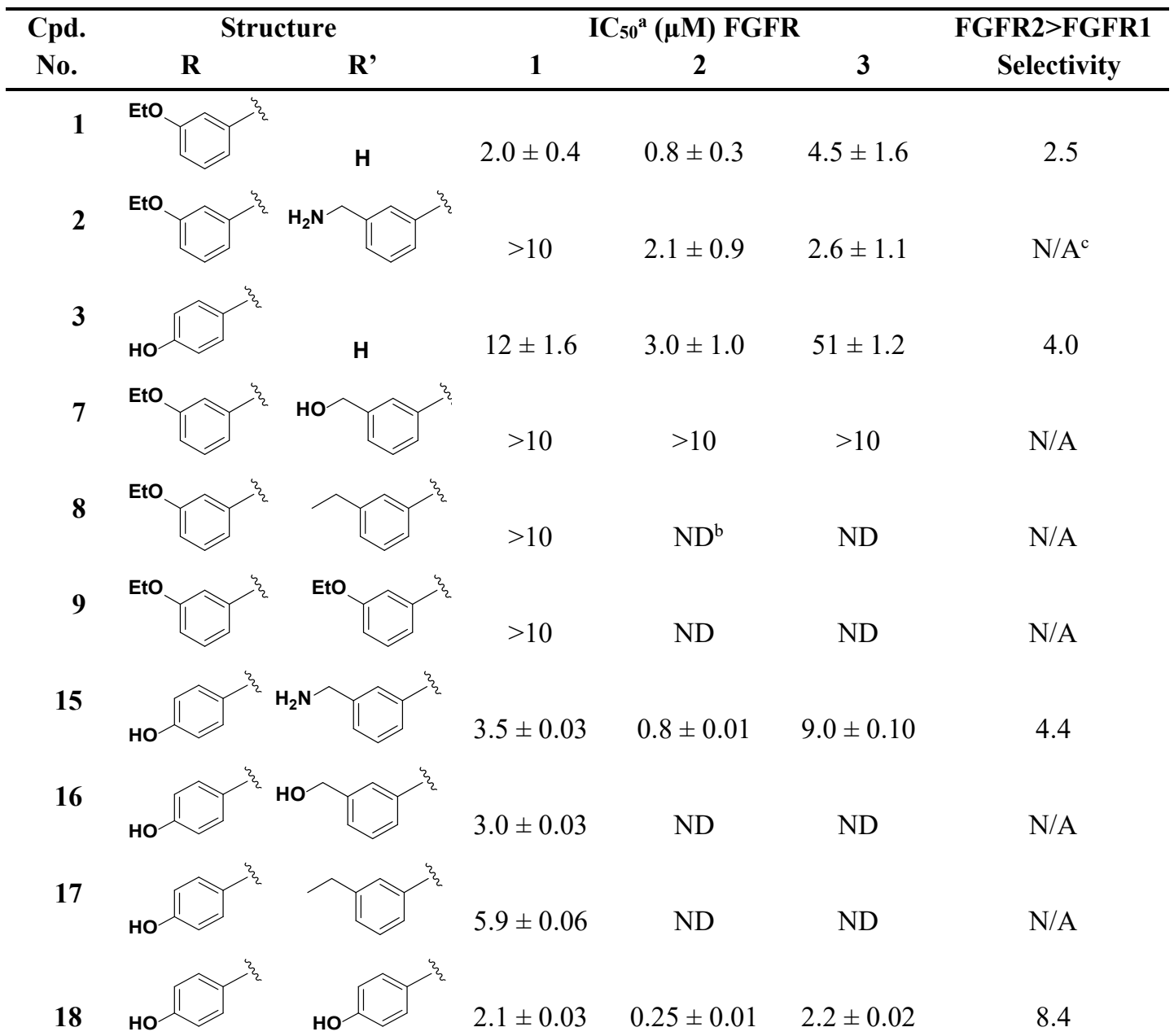

${ }^{a} I C_{50}$ values are given as the mean $\pm S D$ of all data points, $n=2 .{ }^{b} N D=$ not determined. ${ }^{c} N / A=$ not applicable

There are several examples of FGFR inhibitors that possess an indazole scaffold within the literature. ${ }^{42,48,52,53}$ Liu et al. have reported an indazole-based FGFR inhibitor that possessed a similar 
pharmacophore to ours, with one major difference, the presence of an amide group between the indazole and the 3-position phenyl ring. ${ }^{54}$ Structural data confirmed that the lead inhibitor described by Liu et al. occupies the ATP-binding pocket and reveals the amide $\mathrm{NH}$ to be involved in a H-bond donor interaction with the backbone carbonyl of Ala564 near the entrance of the pocket (Figure S3). To explore the importance of the amide and the phenyl ring, we designed a small library of control compounds containing these features (Figure 4).
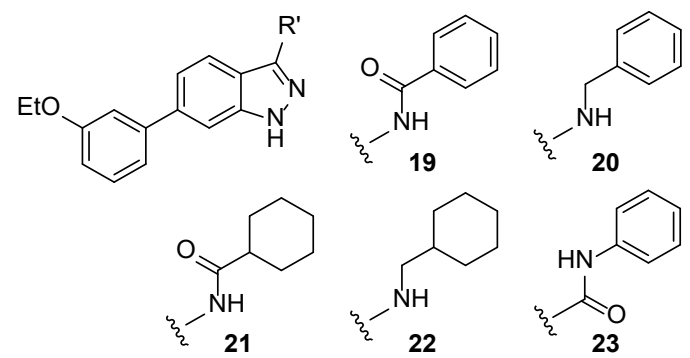

Figure 4: Library probing the importance of the amide and 3-position decoration.

Compounds 19-23 would establish SARs regarding flexibility, positioning of the carbonyl, and what degree of planarity is tolerated toward the entrance of the ATP-binding pocket. Synthesis began with formation of $\mathbf{2 5}$ from $\mathbf{2 4}$ via $\mathrm{S}_{\mathrm{N}} \mathrm{Ar}$ and intramolecular cyclisation with hydrazine followed by Suzuki chemistry to yield 26 (Scheme 2). Direct reductive amination using sodium triacetoxyborohydride (STAB) in the formation of $\mathbf{2 2}$ from $\mathbf{2 6}$ proceeded in low yield - preferential reaction at the 1-position $\mathrm{NH}$ over the 3-position $\mathrm{NH}_{2}$ being a major competitive process.

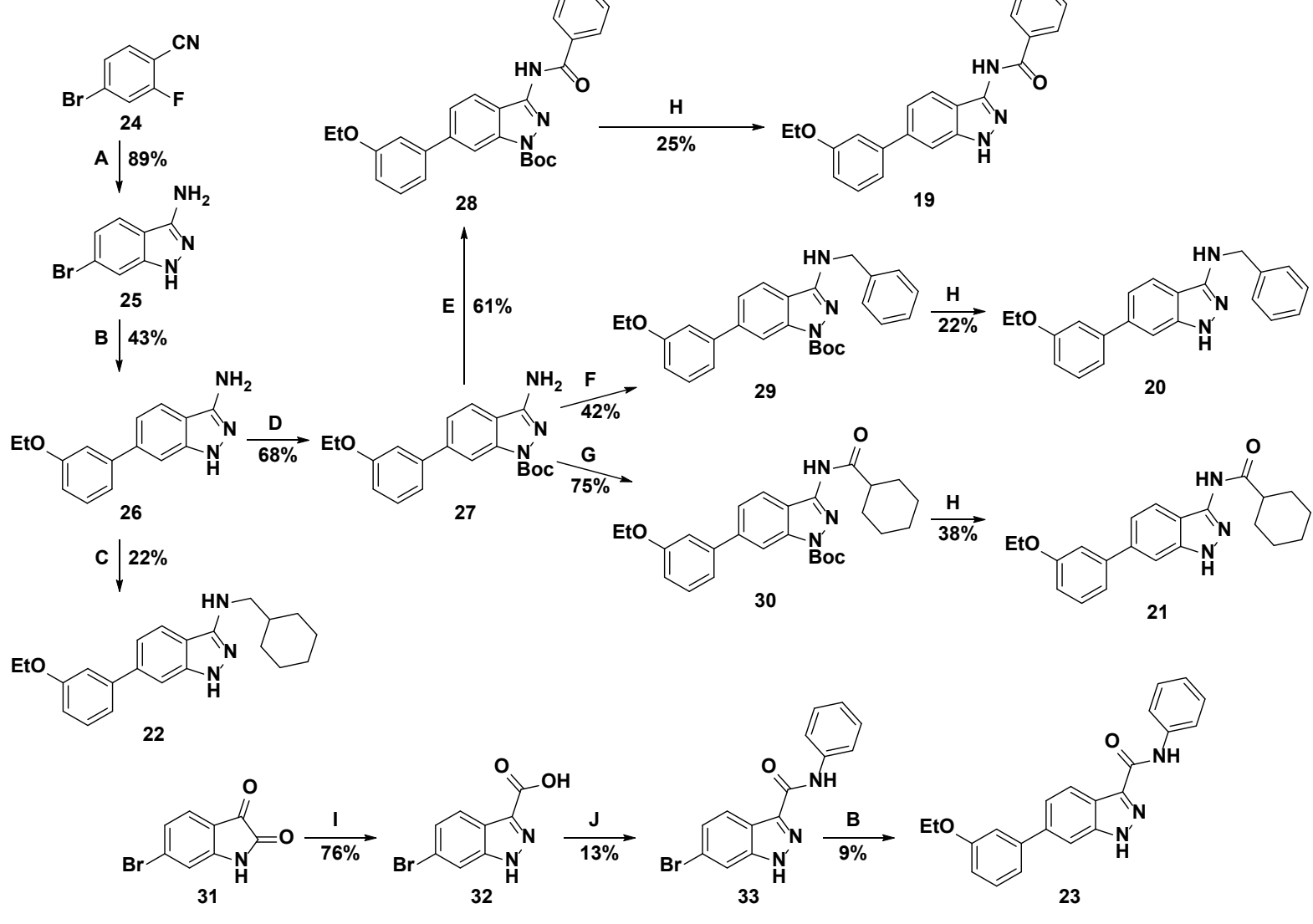


Scheme 2: Synthetic route to amide-based control compounds. Reagents and conditions: (A) $\mathrm{N}_{2} \mathrm{H}_{2}$, ${ }^{n} \mathrm{BuOH}, 100{ }^{\circ} \mathrm{C}, 2$ h. (B) 3-ethoxyphenylboronic acid, $\left.\mathrm{Pd}(\mathrm{dppf}) \mathrm{Cl}_{2}\right), \mathrm{Na}_{2} \mathrm{CO}_{3}$, dioxane: $\mathrm{H}_{2} \mathrm{O}, 110{ }^{\circ} \mathrm{C}$ MW, 2 h (C) Cyclohexanecarboxaldehyde, STAB, AcOH, DCM, 16 h. (D) Boc anhydride, DMAP, DCM, 2 h. (E) Benzoyl chloride, $i \operatorname{Pr}_{2}$ NEt, DCM, 16 h. (F) Benzaldehyde, reductive amination conditions. (G) Cyclohexanecarbonyl chloride, acyl chloride conditions. (H) TFA, DCM, 1 h. (I) i) $\mathrm{NaOH}_{(\mathrm{aq})}, 50{ }^{\circ} \mathrm{C}, 30 \mathrm{~m}$; ii) $\mathrm{NaNO}_{2}, 0{ }^{\circ} \mathrm{C}, 5 \mathrm{~m}$; iii) $\mathrm{H}_{2} \mathrm{SO}_{4}, 0{ }^{\circ} \mathrm{C}, 20 \mathrm{~m}$; iv) $\mathrm{SnCl}_{2}, \mathrm{HCl}, 0{ }^{\circ} \mathrm{C}, 1 \mathrm{~h}$. (J) i) $\mathrm{SOCl}_{2}$, ii) $\mathrm{Et}_{3} \mathrm{~N}$, aniline, $\mathrm{DCM}, 450{ }^{\circ} \mathrm{C}, 4 \mathrm{~h}$.

Moving forward, we employed Boc protection of $\mathbf{2 6}$ to improve the efficiency of subsequent chemistry. Compound 27 was then subjected to amide coupling and reductive amination conditions to give 28-30 which were then deprotected to yield the final compounds. Notably, step E showed formation of the bis-amidated product which was also taken forward for deprotection (Scheme S3) and biological evaluation (Table S2). To obtain inverse amide 23, bromoisatin 31 was subjected to basic hydrolysis followed by diazotisation, reduction, and final ring closure to afford 32. Formation of the amide bond was achieved by in situ acyl chlorination to obtain $\mathbf{3 3}$ which was then subjected to Suzuki coupling to yield the final compound. Compounds 19-23 were screened for activity against FGFR1-3 (Table 2).

Table 2: Biological results for amide-based compounds 19-23.
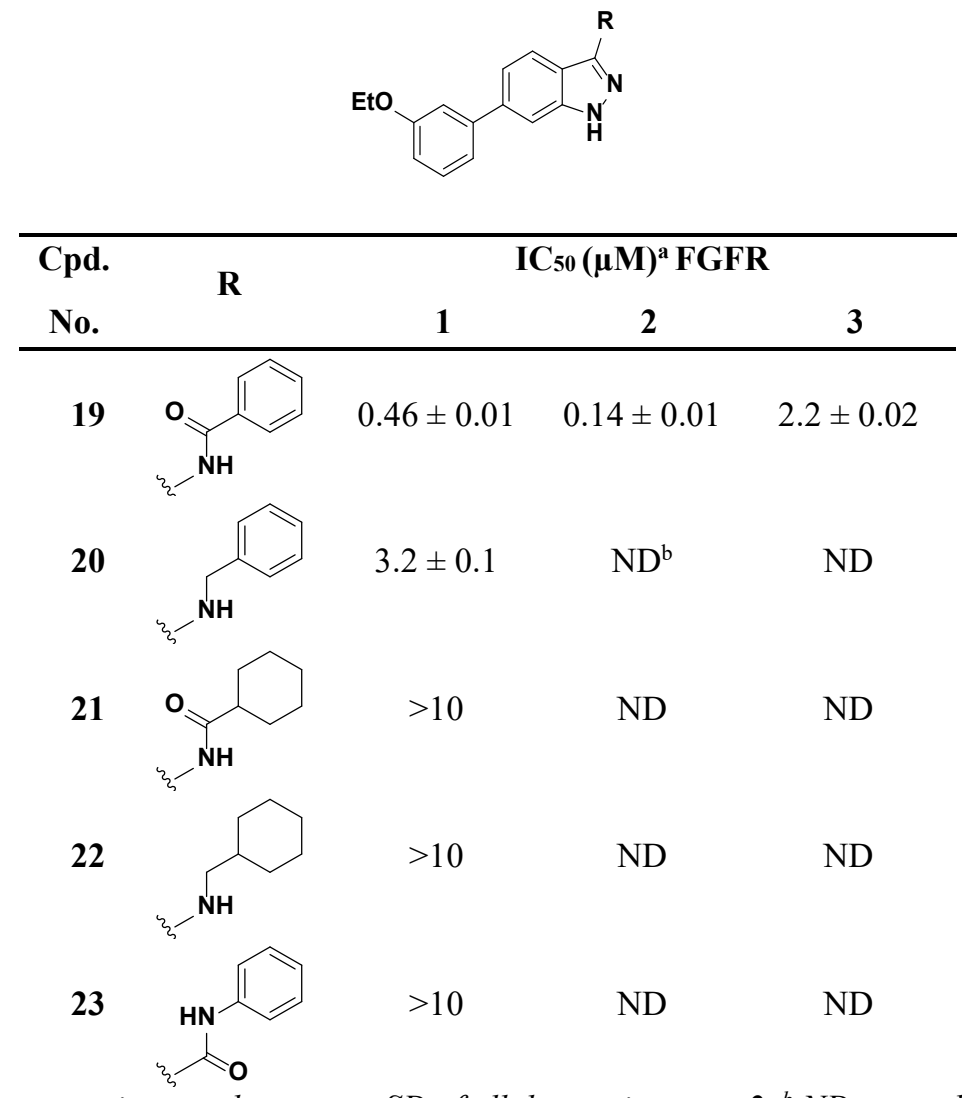

${ }^{a} I C_{50}$ values are given as the mean $\pm S D$ of all data points, $n=2 .{ }^{b} N D=$ not determined .

The inclusion of the amide bond between the indazole and the 3-position phenyl ring appeared crucial. Compound 19 exhibited $\mathrm{IC}_{50}$ values of $0.46,0.14$ and $2.2 \mu \mathrm{M}$ against FGFR1-3, respectively, which 
was a significant increase in potency when compared to 1 and $\mathbf{2}$ (Table 1). Interestingly, removal of the amide carbonyl (20) resulted in a $\sim 7$-fold loss of potency. The somewhat planar amide bond restricts the conformational flexibility at the 3-position, possibly placing the aromatic ring in a more favourable conformation when compared to the reduced amide version 20. Compounds 21 and 22 were both inactive. This suggested that optimal substituents at the 3-position need to be planar and possess a linear trajectory, such as flat aromatic rings. Notably, testing of inverse amide $\mathbf{2 3}$ revealed a complete loss of potency which provided strong support for the importance of the H-bond between the amide carbonyl and the backbone NH of Ala564 (Figure S3).

Compound 19 exhibited a $\sim 3$-fold selectivity preference for FGFR2 over FGFR1, a drop from the $\sim 8$-fold preference that was observed with bis-phenol 18. There were two major differences between these compounds: the substituent on the 6-position phenyl ring and the nature of the 3-position foliage. To determine the selectivity 'handle' for 18, we designed, synthesised (Scheme S4), and biologically evaluated compound $\mathbf{3 4}$ which incorporated the 3-position amide bond and the phenol simultaneously (Table 3).

Table 3: Biological results for compounds 18, 19 and 34 when screened against FGFR1-3. Areas implicated in selectivity differences are outlined in red.

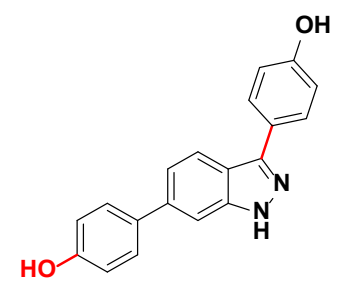

18

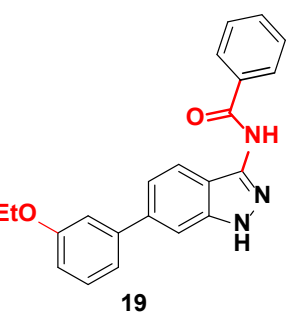

19

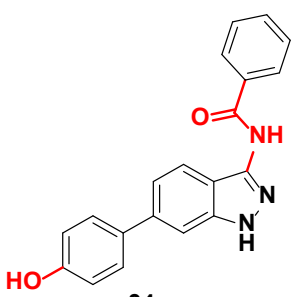

34

\begin{tabular}{|c|c|c|c|c|}
\hline Cpd. & & $\mathrm{IC}_{50}(\mu \mathrm{M})^{\mathrm{a}}$ & & FGFR2>FGFR1 \\
\hline No. & 1 & 2 & 3 & Selectivity \\
\hline 18 & $2.1 \pm 0.03$ & $0.25 \pm 0.01$ & $2.2 \pm 0.02$ & 8.4 \\
\hline 19 & $0.46 \pm 0.01$ & $0.14 \pm 0.01$ & $2.2 \pm 0.02$ & 3.3 \\
\hline 34 & $0.40 \pm 0.01$ & $0.11 \pm 0.01$ & $3.5 \pm 0.03$ & 3.6 \\
\hline
\end{tabular}

${ }^{a} I C_{50}$ values are given as the mean $\pm S D$ of all data points, $n=2$.

Inclusion of an amide into the phenol-based compound resulted in a potency increase against FGFR1 and FGFR2. However, the selectivity preference for FGFR2 dropped from 8.4- to 3.6-fold for compounds 18 and 34, respectively. This suggested that the most influential aspect governing FGFR2 selectivity for compound $\mathbf{1 8}$ was the linear trajectory of the 3-position foliage, however, it is a combination of both the phenol and the linear aryl-aryl bond that dictates FGFR2 selectivity. To further investigate the selectivity profile of $\mathbf{3 4}$, we evaluated its inhibition against FGFR4, and it possessed no activity ( $\mathrm{IC}_{50}>10 \mu \mathrm{M}$, data not shown). To further develop our inhibitors, we posited that substitution of a larger, linear, and more hydrophilic 3-position group would improve potency, solubility, and most 
importantly, the selectivity for FGFR2. Literature precedent outlined the use of piperazine as a useful group to improve the pharmacokinetic profile for inhibitors of FGFR kinases. ${ }^{46,48}$ Using this rationale, we designed and synthesised $\mathbf{3 8}$ (Scheme 3).

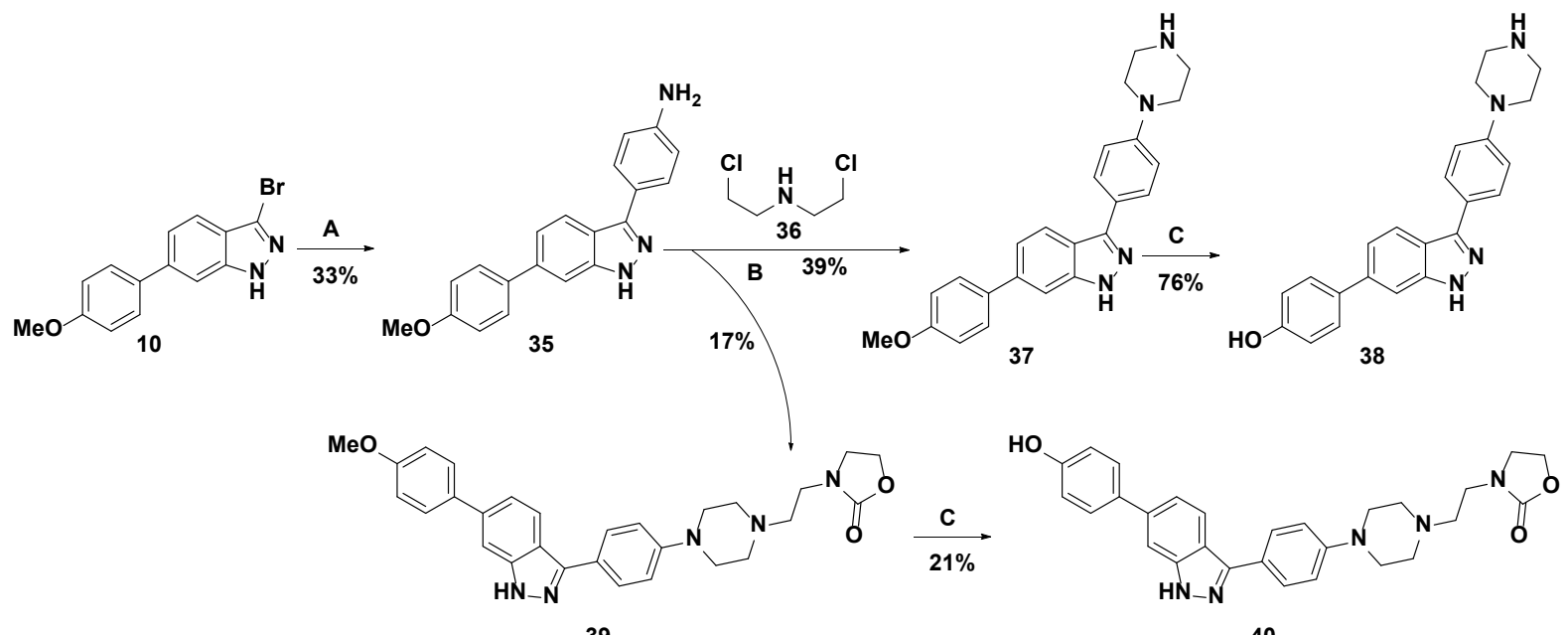

39

40

Scheme 3: Synthetic route employed to obtain 38. Oxazolidinone 39 formed as a side-product through over-substitution with 36. Reagents and conditions: (A) 4-aminophenylboroninc acid pinacol ester, $\mathrm{Pd}\left(\right.$ dppf) $\mathrm{Cl}_{2}$ ), $\mathrm{Na}_{2} \mathrm{CO}_{3}$, dioxane: $\mathrm{H}_{2} \mathrm{O}, 110{ }^{\circ} \mathrm{C} \mathrm{MW}, 2$ h. (B) 36, $\mathrm{K}_{2} \mathrm{CO}_{3},{ }^{\mathrm{t}} \mathrm{BuOH}, 100{ }^{\circ} \mathrm{C}, 100$ h. (C) $\mathrm{BBr}_{3}$, DCM, $1 \mathrm{~h}$.

Compound $\mathbf{1 0}$ was subjected to Suzuki chemistry to install the aniline functionality of $\mathbf{3 5}$. This then underwent a double $\mathrm{S}_{\mathrm{N}} 2$ reaction with $\mathbf{3 6}$ followed by a final deprotection with $\mathrm{BBr}_{3}$ to afford the target compound 38. Interestingly, during the $\mathrm{S}_{\mathrm{N}} 2$ reaction an unknown side-product was isolated, characterised, and determined to be compound 39 which was also taken forward for deprotection to obtain 40. We have proposed a mechanism for the formation of $\mathbf{3 9}$ (Figure S4) and this is the first example of a one-pot synthesis of a piperizyl-ethylene-oxazolidinone core from an aniline precursor. In addition to 38 and 40, several other piperazyl derivatives (41-44) based on previous fluoro-phenol fragments ${ }^{42}$ were also synthesised (Scheme S5) and evaluated for inhibition against FGFR1-3 (Table 4).

Table 4: Biological results for compounds $\mathbf{3 8}$ and $\mathbf{4 0 - 4 4}$ when screened against FGFR1-3.

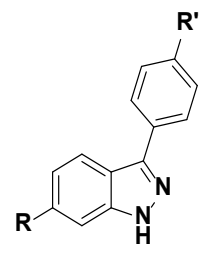

\begin{tabular}{ccccccc}
\hline Cpd. & \multicolumn{2}{c}{ Structure } & \multicolumn{3}{c}{ IC $_{50}{ }^{\mathbf{a}}(\mathbf{n M})$ FGFR } & \multicolumn{2}{c}{ FGFR2>FGFR1 } \\
No. & $\mathbf{R}$ & $\mathbf{R}$ & $\mathbf{1}$ & $\mathbf{2}$ & $\mathbf{3}$ & Selectivity \\
\hline $\mathbf{3 8}$ & & & &
\end{tabular}


40<smiles>Oc1ccc(I)cc1</smiles><smiles>CCN1CCCN(CCN2CCCC2=O)CC1</smiles>

41<smiles>Oc1ccc(I)c(F)c1</smiles>

42<smiles>Oc1ccc(I)cc1F</smiles><smiles>[CH]CN1CCNCC1</smiles>

$268 \pm 1$

$258 \pm$

$753 \pm 5$

$135 \pm 7 \quad 77 \pm 5 \quad 501 \pm 2$

43<smiles>Oc1ccc(I)cc1</smiles><smiles>CCN1CCN(CC)CC1</smiles>

$\mathrm{NH}_{2}$

$449 \pm 3 \quad 96 \pm 1 \quad \mathrm{ND}^{\mathrm{b}}$

$204 \pm 3 \quad 77 \pm 1 \quad 915 \pm 6$

44<smiles>Oc1ccc(I)cc1</smiles>

$4200 \pm 40$

$198 \pm 2$

$>10000$

As hypothesised, the addition of the piperazine improved both the potency and selectivity with 38 possessing an $\mathrm{IC}_{50}$ value of $29 \mathrm{nM}$ and a 13 -fold inhibition preference for FGFR2 over FGFR1. Oxazolidinone $\mathbf{4 0}$ showed an improvement in potency when compared to $\mathbf{1 8}$ but was less potent and less selective than 38. Unexpectedly, both 41 and 42, which possess mono-substituted fluorines on the 6-position phenol, exhibited a dramatic loss in FGFR2 selectivity with $\mathbf{4 2}$ displaying no selectivity at all. The presence of the fluorine in $\mathbf{4 1}$ will likely cause an increase in the dihedral angle between the indazole ring and the 6-position phenyl ring by means of gauche interactions. We postulate that the disruption in planarity between the two ring systems is a likely cause for the selectivity drop. The FGFR1 active site may be more accommodating to such changes than the active site of FGFR2. We expect 42 to also have a similar effect, however we expect that this fluorine has a larger impact on the ability of the phenol to H-bond to Glu531, either through electron-withdrawing potential or via an intramolecular H-bond. We have shown previously that the phenol is an important feature when aiming for FGFR2 selectivity (Table 3). This dramatic loss in selectivity was also observed for 43. Conversely, 44 exhibited a large increase in FGFR2 selectivity. Using available structural information for FGFR1 and FGFR2, we conducted docking models to rationalize these subtle SARs but unfortunately no points of selectivity were observed. To gain insight into these observations, we endeavoured to obtain X-ray crystallographic evidence of inhibitor-enzyme complexes to unravel the structural requirements that dictate FGFR2 selectivity.

We performed crystallographic studies using a WT FGFR2 construct (residues 461-763) and an FGFR1 construct (residues 458-765) that harboured two mutations (C488A, C584S). This construct 
has been used extensively in the determination of ligand binding conformations. ${ }^{55-57}$ Compound $\mathbf{3 8}$ was successfully crystallised within FGFR1/2 to a resolution of 1.71 and $2.28 \AA$, respectively. In addition, 19 and 34 were also crystallised in FGFR1 to a resolution of $1.82 \AA$ (Figure 5).

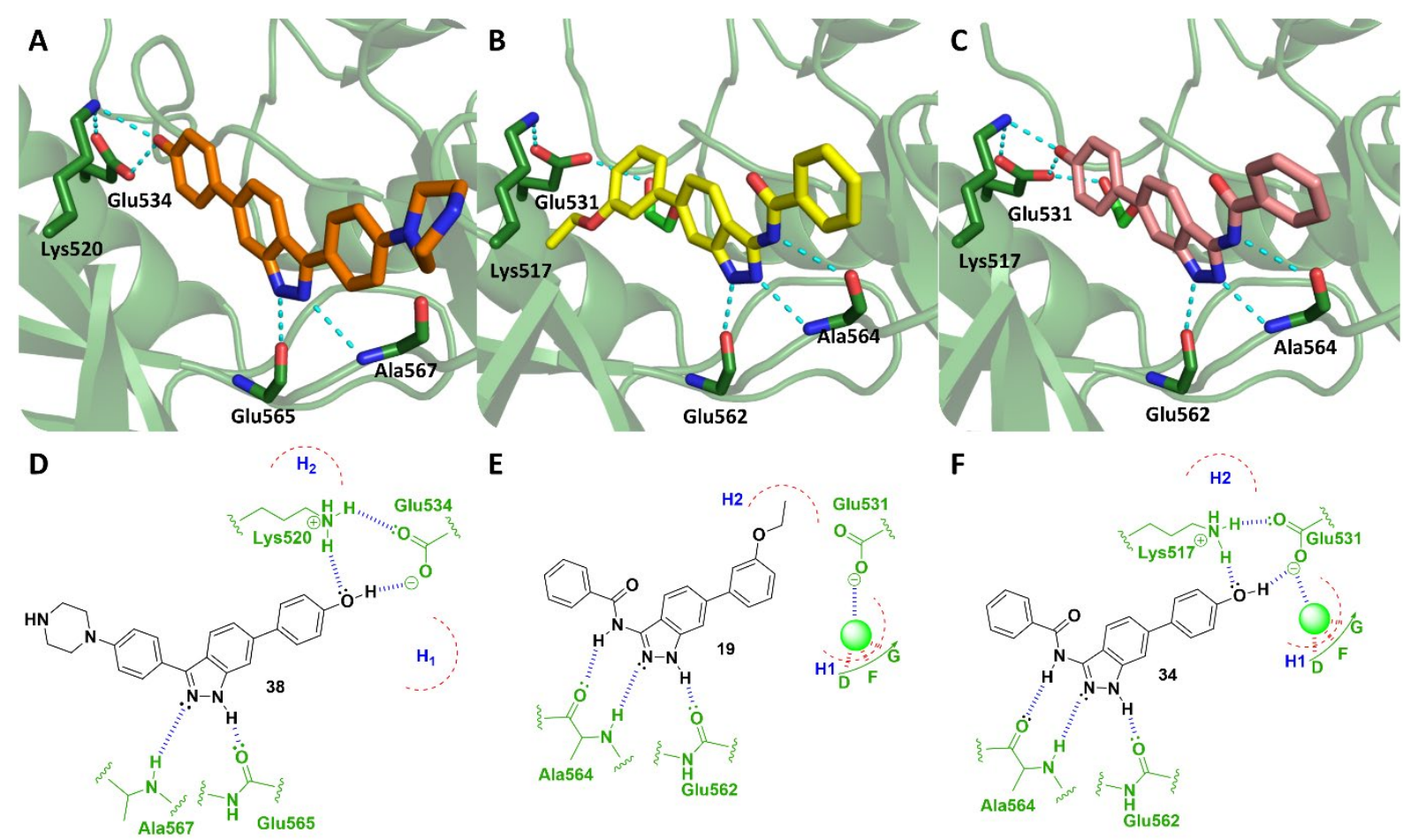

Figure 5: (A) Compound 38 (orange) bound within the ATP binding pocket of FGFR2 (PDB 7OZY). $\mathrm{H}$-bonds are outlined as cyan hashed lines. The phenol is involved in an H-bond network with the side chains of Glu534 and Lys520. (B) Compound 19 (yellow) bound within the ATP binding pocket of FGFR1 (PDB 7OZF). The ethoxy group occupies the H2 sub-pocket. Ethylene glycol occupies the H1 sub-pocket and forms H-bonds with the DFG motif. (C) Compound 34 (pink) bound within the ATP binding pocket of FGFR1 (PDB 7OZD). (D-F) 2D representations of the binding mode of 38, 19 and 34, respectively.

Consistent with other reported FGFR-inhibitor complex structures, FGFR1 with compounds 19, 34, and 38 occupied the ATP binding pocket and exhibited a 'DFG-in' conformation. Compound 38 formed the crucial H-bond donor/acceptor interactions between the indazole nitrogens atoms and Ala567 and Glu565. The phenol participated in an H-bond network with Glu534 and Lys520 and confirmed predictions from earlier docking models that this was important for inhibition. ${ }^{42} \mathrm{We}$ observed the possible presence of either a partially occupied ethylene glycol or water molecules within the H1 pocket. We modelled both ethylene glycol and water in turn, but did not include them in the final structure due to poor resolution. The binding mode of $\mathbf{3 8}$ within FGFR1 (PDB 7OZB, Figure S5) was identical to that of FGFR2 and did not indicate the presence of any selective inhibitor/enzyme interactions. For both the FGFR1 and FGFR2 structures, there were two molecules in the crystallographic asymmetric unit. One of the FGFR1 chains exhibited an alternate conformation for the 
piperazine ring (Figure S6) in which it had distorted inward to form an $\mathrm{H}$-bond between the piperazine NH and the phenol of Tyr563, however, this conformation was not observed in the FGFR2 co-crystal structure. It was unclear whether this partial interaction had any effect on the selectivity profile of $\mathbf{3 8}$. Compound 19 bound in a similar fashion to 38 with two major differences; the amide $\mathrm{NH}$ was involved in an H-bond with the backbone carbonyl of Ala564, and the ethoxy group occupied the H2 sub-pocket, contradicting earlier docking models (Figure 2) that predicted the ethoxy group to occupy the H1 subpocket. Moreover, ethylene glycol, which was present in the crystallography milieu, occupied the H1 pocket forming H-bonds with the DFG motif. Compound $\mathbf{3 4}$ bound in the expected fashion, forming analogous H-bonds to those observed for both 38 and 19.

The direct binding interactions of 19, 34 and $\mathbf{3 8}$ did not allude to any points of selectivity between FGFR1 and FGFR2. Analysis of the protein morphology surrounding the ATP binding pocket for FGFR1 and FGFR2 highlighted different conformations adopted by the P loop (residues 484-491) and the activation loop (residues 641-664) that appeared to be influenced by the bound ligand, and intrinsic differences between FGFR1 and FGFR2, respectively (Figure 6).

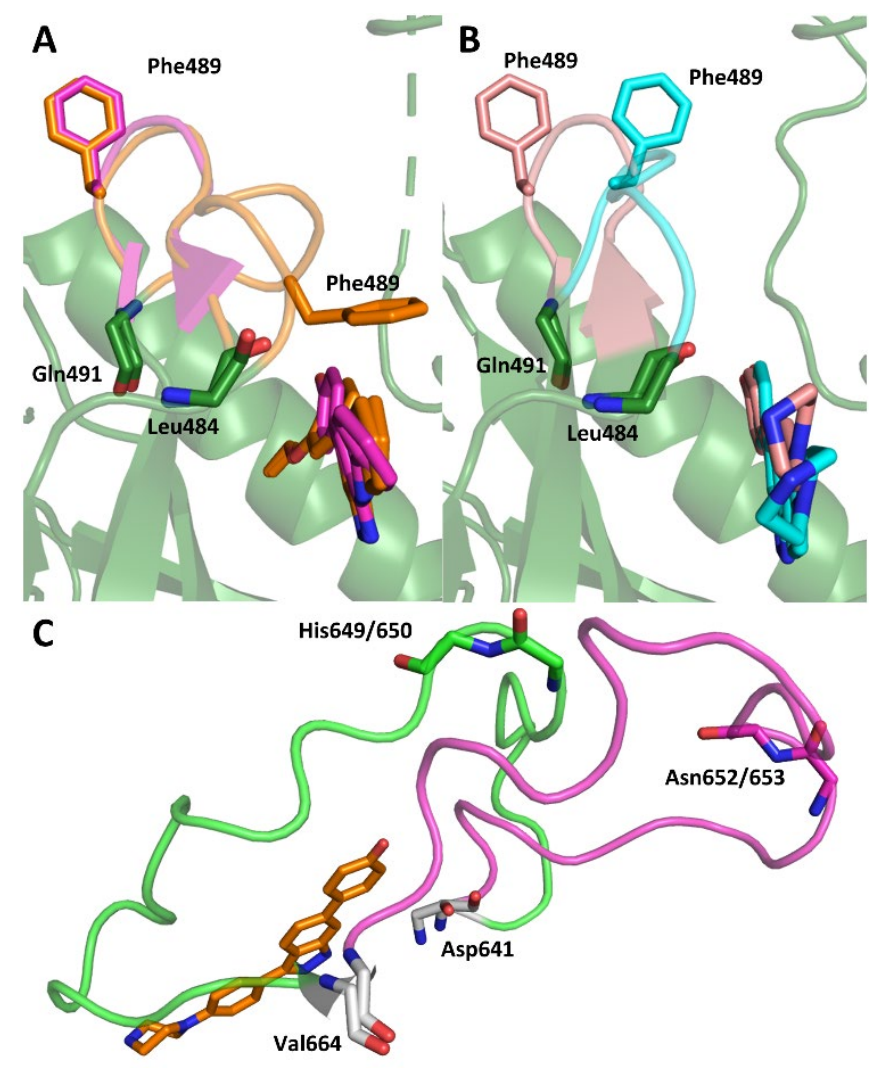

Figure 6: (A) P loop region, residues 484-491 (between $\beta$-strands 1 and 2 of the $\mathrm{N}$-terminal domain). An open P loop conformation was observed for 19 (orange) and 34 (purple). A closed P loop conformation was exclusively observed for $\mathbf{1 9}$ (orange). (B) P loop morphology for $\mathbf{3 8}$ bound within FGFR1 (pink) and FGFR2 (cyan). FGFR1 exhibited an open P loop morphology whereas FGFR2 exhibited an inward shift. (C) Comparison of the activation loop morphology between FGFR1 (green) 
and FGFR2 (purple), non-conserved residues are outlined. Labels for FGFR1/FGFR2 overlays refer to the FGFR1 amino acid number.

The FGFR1/19 complex possessed two distinct conformations within its crystal lattice (Figure 6A). One chain exhibited both an open and closed P loop conformation simultaneously, whereas its counterpart exclusively exhibited a closed loop conformation. The closed P loop conformation has previously been observed using this construct, as was the case for FGFR1 in complex with AZD4547, a pan-FGFR inhibitor currently under clinical evaluation for FGFR-related cancers. ${ }^{57,58}$ We posit that the closed P loop conformation was driven by an edge-to-face $\pi$ - $\pi$ stack between Phe489 and the 6position phenyl ring of $\mathbf{1 9}$. The presence of the 3-ethoxy group likely stabilised this conformation through an anchoring effect via occupation of the $\mathrm{H} 2$ pocket. The electron density map for $\mathbf{1 9}$ was well defined and indicated that rotation around the 6-position phenyl bond would be restricted as the ethoxy group would likely clash with Lys517 (Figure S7A). Compound 34 exhibited an open loop conformation in one of the crystal monomers. Notably, during processing of the crystallographic data, poor connectivity, and electron density for the P loop in the other chain was observed, impeding our ability to reliably model this region. However, we did not observe evidence of a closed-loop conformation. We hypothesise that the lack of the ethoxy 'anchor' enables free rotation of the 6-position phenyl ring which in turn disrupts the edge-to-face $\pi$ - $\pi$ stack with Phe489 and therefore is less likely to adopt a closed loop conformation. Furthermore, the electron density surrounding the 6-position phenyl ring in $\mathbf{3 4}$ was less well-defined (Figure S7B) than for $\mathbf{1 9}$ which suggested more rotational freedom.

An open P loop conformation was also observed for one of the chains of the FGFR1/38 crystal structure with the other chain also possessing a high degree of flexibility which again, we were unable to model. This was also reflected for one of the chains in the FGFR2/38 crystal structure. It is apparent that this loop possesses a high degree of flexibility and likely exists in multiple conformations that are interchangeable. Nevertheless, we did observe an inward shift for this loop within one of the chains of the FGFR2/38 crystal structure (Figure 6B). This inward shift may be indicative of a transitionary state whereby the P loop moves from an open to a closed conformation. Assuming the closed P loop conformation is a more stable structure, it is possible that the observed selectivity preference of $\mathbf{3 8}$ for FGFR2 is due to a closed conformation being more favourable in FGFR2 than FGFR1. Flexibility in the $\mathrm{P}$ loop is well documented and is indicated as a determining factor for the selectivity of inhibitors of kinases $\mathrm{MAP}_{4} \mathrm{~K}_{4}, \mathrm{Abl}$, and Src. ${ }^{59,}{ }^{60}$ In addition, Casaletto et al reported that their highly selective FGFR2 inhibitor RLY-4008 did not show any structural differences between X-ray crystal structures of it bound within FGFR1/2. ${ }^{40}$ Through molecular dynamic modelling, they hypothesised that the observed selectivity resulted from dynamic differences in a flexible loop present in FGFR1 and FGFR2. Specifically, they predicted this flexible loop to switch between an open and closed conformation more rapidly in FGFR1 than FGFR2. ${ }^{40}$ We believe that this hypothesis could refer to the flexibility of the P loop and may offer support for our hypothesis regarding $\mathbf{3 8}$ and its ability to stabilise a closed 
conformation more readily in FGFR2 over FGFR1. However, we acknowledge that our data is insufficient to support this hypothesis and further studies into the fluid dynamics of this region need to be carried out.

Another observed difference between FGFR1 and FGFR2 was the conformation of the activation loop between residues 641-664 (Figure 6C). The activation loop of FGFR1 was positioned over the active site whereas in FGFR2 the loop was situated away from the active site. It is important to note that the activation loop in FGFR2 was packed against a symmetry-related molecule and likely played a significant role in the morphology of this portion of the protein. Furthermore, analysis of available crystal structures of FGFR1 and FGFR2 co-crystallised with pan-FGFR inhibitors (Figure S8) outlined that these differences are an intrinsic phenomenon that are specific to each enzyme and is unlikely to be a determining factor in the selectivity of $\mathbf{3 8}$.

In addition to the differences in the $\mathrm{P}$ loop and activation loop, the selectivity preference of compound $\mathbf{3 8}$ for FGFR2 may also be explained via consideration of the ligand electron density maps within FGFR1/2 (Figure 7).

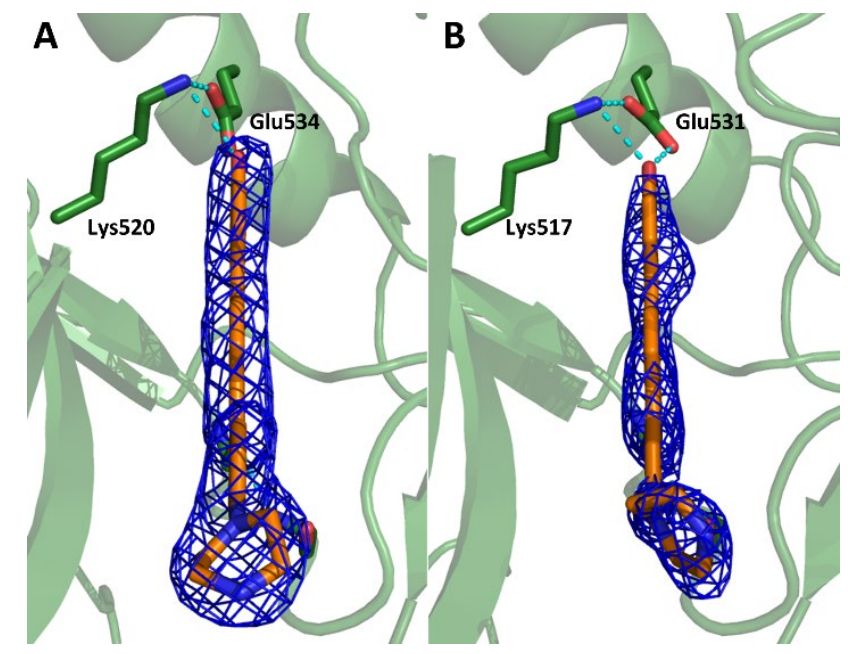

Figure 7: (A-B) $2 F_{\mathrm{o}}-F_{\mathrm{o}}$ electron density maps (contour level $1.0 \sigma$ ) for $\mathbf{3 8}$ bound within FGFR2 and FGFR1, respectively. FGFR1/38 shows a slight spherical perturbation surrounding the 6-position phenyl ring.

The ligand electron density map for compound $\mathbf{3 8}$ in FGFR2 was well defined with flat edges flanking the planar 6-position phenyl ring. As was observed for 34 (Figure S7B), the electron density for 38 bound within FGFR1 exhibited a slight spherical perturbation which indicated more rotational freedom of the 6-position phenyl ring. This evidence bolsters the earlier hypothesis that an increase in the dihedral angle between the 6-position phenyl and indazole rings is tolerated more in FGFR1 than FGFR2, as exemplified by the lack of FGFR2 selectivity for $\mathbf{4 1}$ and $\mathbf{4 2}$ (Table 4). However, we acknowledge that the resolution difference between the FGFR1 and FGFR2 crystal structures may obscure the finer aspects of ligand binding and care should be taken when drawing these conclusions. 
To establish whether FGFR2 selectivity was translatable to a cellular environment, we decided to conduct cell viability assays for 38, 41, 42 and PD173074 (Table 5). PD173074 is a potent panFGFR inhibitor and was included as a positive control. ${ }^{61}$ Three cell lines were chosen: JMSU1 ${ }^{62}$ (FGFR1-driven ${ }^{63}$ ), SUM52 ${ }^{64}$ (FGFR2/FGFR1-driven ${ }^{65}$ ) and VMCUB3 $^{66}$ (No evidence for FGFR activation).

Table 5: Biological evaluation of compounds 38, 41, 42 and PD173074 against various cancer cell lines.

\begin{tabular}{c|c|c|c}
\hline $\begin{array}{c}\text { Cpd } \\
\text { No. }\end{array}$ & $\begin{array}{c}\text { SUM52 } \\
\mathbf{I C}_{\mathbf{5 0}}{ }^{\mathbf{a}}(\mathbf{n M})\end{array}$ & $\begin{array}{c}\text { JMSU1 } \\
\mathbf{I C}_{\mathbf{5 0}}{ }^{\mathbf{a}}(\mathbf{n M})\end{array}$ & $\begin{array}{c}\text { VMCUB3 } \\
\mathbf{I C}_{\mathbf{5 0}}{ }^{\mathbf{a}}(\mathbf{n M})\end{array}$ \\
\hline $\mathbf{3 8}$ & $700 \pm 100$ & $2100 \pm 150$ & $2000 \pm 250$ \\
$\mathbf{4 1}$ & $600 \pm 150$ & $2000 \pm 150$ & $1650 \pm 100$ \\
$\mathbf{4 2}$ & $1100 \pm 200$ & $3250 \pm 150$ & $2600 \pm 150$ \\
$\mathbf{P D 1 7 3 0 7 4}$ & $8.0 \pm 1.0$ & $1050 \pm 250$ & $4850 \pm 600$ \\
& & \\
&
\end{tabular}

Compound 38 exhibited modest potency against each of the cell lines with an $\mathrm{IC}_{50}$ value of 700 nM against SUM52. Compound 38 exhibited a marginal preference for SUM52 over JMSU1 and VMCUB3 but displayed a significant drop in potency ( 24 -fold) from the enzyme inhibition data and therefore deductions about compound selectivity could not be made. The drop in potency was also reflected with $\mathbf{4 1}$ and $\mathbf{4 2}$ but not for PD173074 which was extremely potent against SUM52 $\left(\mathrm{IC}_{50}=8\right.$ nM). Unexpectedly, PD173074 did not perform well against JMSU1, indicating that it may not be the best cell line to evaluate FGFR1 cellular efficacy. The reduction of potency for $\mathbf{3 8}, \mathbf{4 1}$ and $\mathbf{4 2}$ is likely due to poor cellular permeability from the charged nature of the piperazine secondary amine. Future derivatives will look to maintain FGFR2 selectivity but ablate poor cellular permeability.

\section{Conclusion and Future Outlook}

This work described an extensive structure-guided medicinal chemistry campaign from a starting fragment (1) that exhibited sub-micromolar potency to a lead inhibitor (38) that possessed $\mathrm{nM}$ potency and $>10$-fold selectivity for FGFR2 over FGFR1. We used a combination of classical SAR studies and computational methods such as de novo design and docking to aid in the hit-to-lead process. We were able to show that subtle changes to the lead inhibitor, such as substitution of hydrogen for fluorine, resulted in a complete loss of selectivity for FGFR2. We posited that this phenomenon was due to an increase in the dihedral angle between the 6-position phenyl and indazole ring, which in turn would be better tolerated within FGFR1 over FGFR2. X-ray crystallographic studies outlined that ligand electron density surrounding the 6-position phenyl ring was more spherical in FGFR1 over FGFR2. This indicated more rotational freedom, thus an improved tolerance for larger dihedral angles between both ring systems in FGFR1 than FGFR2. We have also demonstrated that ligand binding to 
FGFR1/2 resulted in significant morphological changes to the P loop. Static snapshots of this loop transitioning between an open- and closed-state, whereby the latter forms a lid above the active site, have alluded to a dynamic selectivity event between FGFR2 and 38, and our findings may complement current theories surrounding selective FGFR2 inhibition. Future work looking to deconvolute the structural aspects and requirements that govern the selectivity preference of $\mathbf{3 8}$ for FGFR2 is currently underway. We also determined that our lead inhibitor suffered from a large decrease in potency between enzyme and cell-based assays. We concluded that it possessed poor cellular permeability owing to the charged nature of the piperazine. In addition to improving cell permeability, we are utilising our own crystal structures in iterative rounds of SBBD to yield more potent and more selective inhibitors of FGFR2 that house the potential to be used as therapeutics for the treatment of FGFR2-implicated cancers.

\section{Experimental Section}

\section{Chemistry - General Procedures and Instrumentation}

All reagents were obtained from commercial sources and were used without further purification unless otherwise stated. All microwave reactions were carried out in a CEM Explorer 48 Autosampler using a power of 200 Watts. Reactions were monitored using TLC and/or LC-MS. TLC was performed using aluminium pre-coated silica gel plates (Merck-chemicals) and visualized using either ultraviolet light $(254 \mathrm{~nm})$, dipping in $\mathrm{KMnO}_{4}$ solution or ninhydrin solution and heated, or using an iodine tank. LC-MS was performed on a Bruker Daltronics instrument running a gradient of increasing MeCN/water (5$95 \%$ ) containing $0.1 \%$ formic acid, at $1 \mathrm{~mL} \mathrm{~min}^{-1}$ on a $50 \times 20 \mathrm{~mm} \mathrm{C}_{18}$ reverse phase (RP) column. Normal phase (NP) flash column chromatography was carried out using Geduran® silica gel 604063 $\mu \mathrm{m}$. Automated column chromatography (ACC) was performed on an Isolera Biotage ${ }^{\circledR}$ using $\mathrm{KP}-\mathrm{C}_{18^{-}}$ HS SNAP 12/30/60 g cartridges using MeCN/water (0-95\%) containing 0.1\% TFA, at a flow rate of 12-50 $\mathrm{mL} \mathrm{min}^{-1}$ for RP, or Thomson Single Step 12/40 g pre-packed silica cartridges for NP. Preparative HPLC was performed on an Agilent 1100 Infinity Series equipped with a UV detector and Ascentis Express $\mathrm{C}_{18}$ reverse phase column using MeCN/water (5-95\%) containing 0.1\% TFA, at a flow rate of $0.5 \mathrm{~mL} \mathrm{~min}{ }^{-1}$ over a period of 15 minutes. Analytical HPLC was performed on an Agilent 1290 Infinity Series equipped with a UV detector and a Hyperclone- $\mathrm{C}_{18} \mathrm{RP}$ column using MeCN/water (5-95\%) containing $0.1 \%$ TFA, at either $0.5 \mathrm{~mL} \mathrm{~min}$ mev $^{-1}$ over a period of five minutes, or $1.0 \mathrm{~mL} \mathrm{~min}{ }^{-1}$ over a period of 30 minutes. All compounds are $>95 \%$ pure by HPLC, unless otherwise stated. HRMS was carried out using a Bruker MaXis Impact Time of Flight spectrometer using ESI (+/-), giving masses correct to four decimal places.

${ }^{1} \mathrm{H}$ NMR spectra were recorded at 501, 500, or $400 \mathrm{MHz}$, respectively, and ${ }^{13} \mathrm{C}$ NMR spectra were recorded at 126 or $101 \mathrm{MHz}$ on either a Bruker Advance 500 or 400 Fourier transform spectrometer. Chemical shifts are reported in ppm and are reported with reference to the residual solvent peak. Multiplicities are reported with coupling constants and are given to the nearest $0.1 \mathrm{~Hz}$. Where needed, 
COSY, HSQC, HMBC, and NOESY were used to aid assignment. Ar-q = aromatic quaternary carbon. IR spectra were recorded in the solid phase on a Bruker Alpha Platinum attenuated total reflectance FTIR spectrometer with vibrational frequencies given in $\mathrm{cm}^{-1}$. Melting points were measured on a Stuart SMP30. Elemental analysis was carried out using a Carlo Erba 1108 Elemental Analyzer.

\section{General Methods}

\section{Method A: Microwave Suzuki Reactions}

A mixture of the chosen halogenated heterocycle (1.0 equiv.), the chosen boronic acid (1.0-2.0 equiv.), $\operatorname{Pd}($ dppf $) \mathrm{Cl}_{2} \bullet \mathrm{DCM}$ (0.1 equiv.) and $\mathrm{Na}_{2} \mathrm{CO}_{3}$ (3.0-5.0 equiv.) were charged with nitrogen in a microwave vial $(10 \mathrm{~mL}$ or $35 \mathrm{~mL})$. A mixture of dioxane and water $((1: 1) 5-20 \mathrm{~mL})$ was degassed for ten minutes and added to the reactants under nitrogen and the reaction mixture was heated to $110^{\circ} \mathrm{C}$ for $1-6 \mathrm{~h}$. The reaction mixture was cooled to $20^{\circ} \mathrm{C}$, diluted with EtOAc and the reaction vessel sonicated and filtered through a celite pad washing thoroughly with EtOAc. Where needed, DCM-MeOH (1:1) was used to wash the celite pad. The filtrate was added to water and the organic layer separated. The aqueous layer was extracted with EtOAc $(\times 3)$ and the combined organic layers were washed with brine, dried $\left(\mathrm{MgSO}_{4}\right)$, and concentrated in vacuo to reveal the crude product. The crude product was purified using either flash chromatography or NP ACC. See individual compounds for purification details.

\section{Method B: Methoxy Deprotections}

The chosen methoxy containing compound (1.0 equiv.) was dissolved/suspended in DCM (5-15 mL) at $0{ }^{\circ} \mathrm{C} .1 \mathrm{M} \mathrm{BBr}_{3}$ in $\mathrm{DCM}$ (2.0-8.0 equiv.) was added slowly and the reaction was stirred at room temperature for 1-24 h until complete. See individual compounds for work up and purification details.

\section{Method C: Boc Deprotections}

The chosen Boc-protected amine (1.0 equiv.) was dissolved in DCM-TFA (1:1) and the reaction was stirred until complete. The reaction mixture was reduced in vacuo to reveal the crude product. See individual compounds for purification details.

\section{Method D: Reductive Aminations}

The chosen aldehyde (1.0-1.2 equiv.) was dissolved in DCM $(3-15 \mathrm{~mL})$ and cooled to $0{ }^{\circ} \mathrm{C}$. The chosen secondary amine (1.0-1.2 equiv.) and glacial $\mathrm{AcOH}$ ( 1 drop) were added, and the reaction was stirred until complete.* Sodium triacetoxyborohydride (STAB) (1.6 equiv.) was added and the was reaction warmed to $20^{\circ} \mathrm{C}$ and stirred until complete. See individual compounds for work up and purification details. *Imine formation for some reactions required the use of $3 \AA$ molecular sieves (MS) and heating to $40{ }^{\circ} \mathrm{C}$.

\section{Method E: Boc Protections}

The chosen amine (1.0 equiv.) was dissolved in THF (20-40 mL) and DMAP (0.3 equiv.) was added, and the reaction stirred for two minutes. Di-tert-butyl dicarbonate (1.1-1.2 equiv.) was added dropwise 
and the was reaction stirred until complete. The reaction mixture was reduced in vacuo to reveal the crude product which was purified by flash chromatography. See individual compounds for purification details.

\section{Method F: Acyl Chloride Couplings}

The chosen amine (1.0 equiv.) was dissolved in DCM (5-20 mL) and $i \operatorname{Pr}_{2} \mathrm{NEt}$ (2.0-3.5 equiv.) was added and the reaction stirred for 20 minutes. The chosen acid chloride (1.2-2.0 equiv.) was added and the reaction stirred until complete. See individual compounds for work up and purification details.

\section{Method G: Piperazine Cyclizations}

The chosen aniline (1.0 equiv.), bis(2-chloroethyl)amine hydrochloride* (36, 1.2 equiv.) and $\mathrm{K}_{2} \mathrm{CO}_{3}$ (2.4 equiv.) were suspended in ${ }^{\mathrm{t}} \mathrm{BuOH}(5-15 \mathrm{~mL})$ and the reaction was heated to $100{ }^{\circ} \mathrm{C}$ and stirred until complete. See individual compounds for work up and purification details. *36 is a mustard gas precursor and presents significant risk, practice extreme caution when conducting this procedure.

\section{Compounds}

\{3-[6-(3-ethoxyphenyl)-1H-indazol-3-yl]phenyl\}methanamine (2)

Synthesised by method A using 6 (150 mg, $0.47 \mathrm{mmol}, 1.0$ equiv.), 3-(aminomethyl)phenylboronic acid $\bullet \mathrm{HCl}$ (133 mg, $0.71 \mathrm{mmol}, 1.5$ equiv.), $\mathrm{Pd}(\mathrm{dppf}) \mathrm{Cl}_{2} \bullet \mathrm{DCM}$ (39 mg, $0.05 \mathrm{mmol}, 0.1$ equiv.), $\mathrm{Na}_{2} \mathrm{CO}_{3}$ (250 mg, $2.36 \mathrm{mmol}, 5.0$ equiv.), dioxane $(5 \mathrm{~mL})$ and water $(5 \mathrm{~mL})$ and the reaction was heated for 2 h. The crude product was purified using flash column chromatography (isocratic: $3: 10: 87,7.0 \mathrm{M} \mathrm{NH}_{3}$ in $\mathrm{MeOH}-\mathrm{MeOH}-\mathrm{EtOAc}$ ) and the resulting brown semi-solid was triturated with DCM to give the titled compound (10 mg, $0.03 \mathrm{mmol}, 6 \%$ ) as colourless granules. ${ }^{1} \mathbf{H}$ NMR (500 MHz, DMSO-d $)$ ): 8.16 (d, $J=8.5 \mathrm{~Hz}, 1 \mathrm{H}), 7.99$ (d, $J=1.8 \mathrm{~Hz}, 1 \mathrm{H}), 7.85$ (dt, $J=7.6,1.5 \mathrm{~Hz}, 1 \mathrm{H}), 7.79-7.75(\mathrm{~m}, 1 \mathrm{H}), 7.51$ $(\mathrm{dd}, J=8.6,1.6 \mathrm{~Hz}, 1 \mathrm{H}), 7.46(\mathrm{t}, J=7.6 \mathrm{~Hz}, 1 \mathrm{H}), 7.41(\mathrm{t}, J=7.9 \mathrm{~Hz}, 1 \mathrm{H}), 7.38-7.34(\mathrm{~m}, 1 \mathrm{H}), 7.31$ (dt, $J=7.8,1.2 \mathrm{~Hz}, 1 \mathrm{H}), 7.26$ (t, $J=2.1 \mathrm{~Hz}, 1 \mathrm{H}), 6.98-6.94(\mathrm{~m}, 1 \mathrm{H}), 4.13(\mathrm{q}, J=6.9 \mathrm{~Hz}, 2 \mathrm{H}), 3.84$ (s, 2H), 1.37 (t, $J=7.0 \mathrm{~Hz}, 3 \mathrm{H}) .{ }^{13} \mathbf{C}$ NMR (126 MHz, DMSO-d $)$ : 159.0, 144.9, 143.3, 142.3, 141.9, 138.3, 133.5, 130.0, 128.6, 126.5, 125.4, 124.6, 121.2, 120.8, 119.5, 119.4, 113.6, 113.2, 108.2, 63.1, 45.7, 30.7, 14.7. HPLC: $\mathrm{RT}=2.27$ min. HRMS (ESI+): Found: $366.1581\left(\mathrm{M}+\mathrm{Na}^{+}\right), \mathrm{C}_{22} \mathrm{H}_{21} \mathrm{~N}_{3} \mathrm{NaO}$ requires MH 366.1577.

3-Bromo-6-iodo- $1 H$-indazole (5)

6-Iodo- $1 H$-indazole (3.00 g, $12.3 \mathrm{mmol}, 1.0$ equiv.) was dissolved in DMF (30 mL) and NBS (2.01 g, $13.5 \mathrm{mmol}, 1.1$ equiv.) was added to the reaction mixture and the solution was stirred for $3 \mathrm{~h}$. Water $(60 \mathrm{~mL})$ was added, and the resulting precipitate was filtered. The crude product was crystallised from EtOH and the titled compound (3.72 g, $11.5 \mathrm{mmol}, 94 \%)$ was collected as yellow microcrystals. ${ }^{1} \mathbf{H}$ NMR (501 MHz, DMSO-d $)_{\text {): }} 8.00(\mathrm{t}, J=1.0 \mathrm{~Hz}, 1 \mathrm{H}), 7.50(\mathrm{dd}, J=8.5,1.3 \mathrm{~Hz}, 1 \mathrm{H}), 7.39$ (dd, $J=8.5,0.8$ Hz, 1H). ${ }^{13}$ C NMR (126 MHz, DMSO-d 6 ): 142.2, 130.0, 121.4, 121.0, 120.8, 119.5, 93.9. LC-MS (ESI+): 
$\mathrm{RT}=1.95-2.10 \mathrm{~min}, \mathrm{~m} / \mathrm{z}=323.0\left(\mathrm{M}+\mathrm{H}^{+}\right)$. mp: $230.4-231.7^{\circ} \mathrm{C}$. Anal. Calcd for $\mathrm{C}_{7} \mathrm{H}_{4} \mathrm{BrIN}_{2}: \mathrm{C}, 26.3$; H, 1.20; N, 8.7. Found: C, 26.4; H, 1.20; N, 8.7.

3-Bromo-6-(3-ethoxyphenyl)-1H-indazole (6)

Synthesised by method A using 5 (500 mg, $1.55 \mathrm{mmol}, 1.0$ equiv.), 3-ethoxyphenylboronic acid (385 mg, $2.32 \mathrm{mmol}, 1.5$ equiv.), $\mathrm{Pd}(\mathrm{dppf}) \mathrm{Cl}_{2} \cdot \mathrm{DCM}$ (126 mg, $0.155 \mathrm{mmol}, 0.1$ equiv.), $\mathrm{Na}_{2} \mathrm{CO}_{3}$ (492 $\mathrm{mg}, 4.64 \mathrm{mmol}, 3.0$ equiv.), dioxane $(10 \mathrm{~mL})$ and water $(10 \mathrm{~mL})$ and the reaction was heated for $3 \mathrm{~h}$. The crude product was purified using flash column chromatography (isocratic: 1:4 EtOAc-hexane) and the resulting solid was crystallised from cyclohexane and the titled compound $(207 \mathrm{mg}, 0.65 \mathrm{mmol}$, 42\%) was collected as colourless flakes. ${ }^{1} \mathbf{H}$ NMR (501 MHz, $\mathbf{C D C l}_{3}$ ): 10.57 (br.s, 1H), 7.72-7.64 (m, 2H), 7.49 (dd, $J=8.4,1.4 \mathrm{~Hz}, 1 \mathrm{H}), 7.38$ (t, $J=7.9 \mathrm{~Hz}, 1 \mathrm{H}), 7.21$ (ddd, $J=7.7,1.7,0.9 \mathrm{~Hz}, 1 \mathrm{H}), 7.17$ (t, $J=2.2 \mathrm{~Hz}, 1 \mathrm{H}), 6.94(\mathrm{ddd}, J=8.2,2.6,1.0 \mathrm{~Hz}, 1 \mathrm{H}), 4.12$ (q, $J=7.0 \mathrm{~Hz}, 2 \mathrm{H}), 1.46$ (t, $J=7.0 \mathrm{~Hz}$, 3H). ${ }^{13} \mathbf{C}$ NMR (126 MHz, $\left.\mathbf{C D C l}_{3}\right): 159.6,142.4,142.0,141.9,130.1,123.2,122.7,122.4,120.5$, 120.1, 114.3, 113.9, 108.3, 63.8, 15.0. LC-MS (ESI+): RT = 1.95-2.01 min, $\mathrm{m} / \mathrm{z}=317.1\left(\mathrm{M}+\mathrm{H}^{+}\right)$. mp: 132.9-133.4 ${ }^{\circ} \mathrm{C}$. Anal. Calcd for $\mathrm{C}_{15} \mathrm{H}_{13} \mathrm{BrN}_{2} \mathrm{O}: \mathrm{C}, 56.7 ; \mathrm{H}, 4.10 ; \mathrm{N}, 8.8$. Found: C, 56.8; H, 4.13; N, 8.8.

\{3-[6-(3-ethoxyphenyl)-1 $H$-indazol-3-yl]phenyl $\}$ methanol (7)

Synthesised by method A using 3-(hydroxymethyl)phenylboronic acid (108 mg, $0.71 \mathrm{mmol}, 1.5$ equiv.) and the same reagents and amounts that are outlined in the preparation of $\mathbf{2}$ and the reaction was heated for $3 \mathrm{~h}$. The crude product was purified using flash column chromatography (isocratic: 1:4 EtOAc-hexane) and the resulting yellow solid was triturated with DCM to give the titled compound (71 $\mathrm{mg}, 0.21 \mathrm{mmol}, 44 \%$ ) as a colourless solid.

${ }^{1}$ H NMR (501 MHz, DMSO-d $)$ ): 8.14 (d, $\left.J=8.5 \mathrm{~Hz}, 1 \mathrm{H}\right), 8.00$ (d, $\left.J=1.8 \mathrm{~Hz}, 1 \mathrm{H}\right), 7.89$ (dt, $J=7.7$, $1.5 \mathrm{~Hz}, 1 \mathrm{H}), 7.78(\mathrm{~d}, J=1.6 \mathrm{~Hz}, 1 \mathrm{H}), 7.54-7.45(\mathrm{~m}, 2 \mathrm{H}), 7.40(\mathrm{t}, J=7.9 \mathrm{~Hz}, 1 \mathrm{H}), 7.35(\mathrm{~d}, J=7.6 \mathrm{~Hz}$, $1 \mathrm{H}), 7.31(\mathrm{dt}, J=7.8,1.2 \mathrm{~Hz}, 1 \mathrm{H}), 7.26(\mathrm{t}, J=2.1 \mathrm{~Hz}, 1 \mathrm{H}), 6.99-6.93(\mathrm{~m}, 1 \mathrm{H}), 5.29(\mathrm{t}, J=5.8 \mathrm{~Hz}, 1 \mathrm{H})$, $4.63(\mathrm{~d}, J=5.8 \mathrm{~Hz}, 2 \mathrm{H}), 4.13$ (q, $J=7.0 \mathrm{~Hz}, 2 \mathrm{H}), 1.37$ (t, $J=6.9 \mathrm{~Hz}, 3 \mathrm{H}) .{ }^{13} \mathbf{C}$ NMR (126 MHz, DMSO-d 6 ): $159.0,143.2,143.2,142.2,141.9,138.3,133.5,130.0,128.6,125.8,125.0,124.7,121.1$, $120.8,119.5,119.4,113.6,113.2,108.2,91.4,63.1,62.9,30.6$, 14.7. HPLC: RT $=2.88 \mathrm{~min}$. HRMS (ESI+): Found: $345.1610\left(\mathrm{M}+\mathrm{H}^{+}\right), \mathrm{C}_{22} \mathrm{H}_{20} \mathrm{~N}_{2} \mathrm{O}_{2}$ requires $M H 345.1598$.

6-(3-ethoxyphenyl)-3-(3-ethylphenyl)-1 $H$-indazole (8)

Synthesised by method A using 3-ethylphenylboronic acid (106 mg, $0.71 \mathrm{mmol}, 1.5$ equiv.) and the same reagents and amounts that are outlined in the preparation of $\mathbf{2}$ and the reaction was heated for $2.5 \mathrm{~h}$. The crude product was purified using flash column chromatography (isocratic: 1:4 EtOAc-hexane). The resulting colourless semi-solid was dissolved in $\mathrm{Et}_{2} \mathrm{O}$ and reduced in vacuo to give the titled compound (73 mg, $0.21 \mathrm{mmol}, 45 \%$ ) as a foamy off-white solid. ${ }^{1} \mathbf{H}$ NMR (501 $\mathbf{~ M H z}$, $\left.\mathbf{C D C l}_{3}\right): 8.06(\mathrm{dd}, J=8.5,0.8 \mathrm{~Hz}, 1 \mathrm{H}), 7.93-7.86(\mathrm{~m}, 2 \mathrm{H}), 7.51-7.44(\mathrm{~m}, 2 \mathrm{H}), 7.41-7.34(\mathrm{~m}, 2 \mathrm{H}), 7.29$ 
(dt, $J=7.7,1.5 \mathrm{~Hz}, 1 \mathrm{H}), 7.18-7.12(\mathrm{~m}, 2 \mathrm{H}), 6.93(\mathrm{ddd}, J=8.4,2.5,1.2 \mathrm{~Hz}, 1 \mathrm{H}), 4.13(\mathrm{q}, J=7.0 \mathrm{~Hz}$, 2H), 2.73 (q, $J=7.6 \mathrm{~Hz}, 2 \mathrm{H}), 1.49$ (t, $J=7.0 \mathrm{~Hz}, 3 \mathrm{H}), 1.26$ (t, $J=7.6 \mathrm{~Hz}, 3 \mathrm{H}) .{ }^{13} \mathbf{C}$ NMR (126 MHz, $\left.\mathbf{C D C l}_{3}\right):$ 159.4, 146.0, 145.2, 142.7, 142.5, 140.2, 133.6, 129.8, 129.1, 128.1, 127.4, 125.3, 121.7, 121.4, 120.5, 120.1 1 14.3 113.4, 108.6, 63.7, 29.1, 15.6, 15.1. HPLC: RT = 3.95 min. HRMS (ESI+): Found: $365.1628\left(\mathrm{M}+\mathrm{Na}^{+}\right), \mathrm{C}_{23} \mathrm{H}_{22} \mathrm{~N}_{2} \mathrm{NaO}$ requires $M H 365.1624$.

\section{3,6-bis(3-ethoxyphenyl)-1 $H$-indazole (9)}

Synthesised as a side product and isolated in the purification of $\mathbf{6}$. The titled compound (107 $\mathrm{mg}, 0.30$ mmol, 19\%) was collected as a fluffy beige powder. ${ }^{1} \mathbf{H}$ NMR (501 $\left.\mathbf{~ M H z}, \mathbf{C D C l}_{3}\right): 8.05$ (dd, $J=8.6$, $1.1 \mathrm{~Hz}, 1 \mathrm{H}), 7.68-7.63(\mathrm{~m}, 1 \mathrm{H}), 7.63-7.60(\mathrm{~m}, 1 \mathrm{H}), 7.48-7.42(\mathrm{~m}, 2 \mathrm{H}), 7.39-7.32(\mathrm{~m}, 2 \mathrm{H}), 7.17-7.11$ (m, 2H), $6.98(\mathrm{ddt}, J=8.2,2.3,1.1 \mathrm{~Hz}, 1 \mathrm{H}), 6.93(\mathrm{ddt}, J=8.2,2.3,1.1 \mathrm{~Hz}, 1 \mathrm{H}), 4.16-4.09$ (m, 2H), 4.09-3.98 (m, 2H), 1.55-1.45 (m, 3H), 1.43-1.35 (m, 3H). ${ }^{13} \mathbf{C}$ NMR (126 MHz, CDCl $)$ : 159.6, 159.4, 145.6, 142.7, 142.5, 140.3, 134.9, 130.2, 129.8, 121.7, 121.3, 120.4, 120.2, 120.1, 114.9, 114.2, 113.74 , 113.72, 113.5, 108.68, 108.65, 63.7, 63.6, 15.0, 14.9. HPLC: RT = 3.14 min. HRMS (ESI+): Found: $359.1764\left(\mathrm{M}+\mathrm{H}^{+}\right), \mathrm{C}_{23} \mathrm{H}_{22} \mathrm{~N}_{2} \mathrm{O}_{2}$ requires $M H 359.1754$.

3-Bromo-6-(4-methoxyphenyl)-1H-indazole (10)

Synthesised by method A using 5 (500 $\mathrm{mg}, 1.55 \mathrm{mmol}, 1.0$ equiv.), 4-methoxyphenylboronic acid (353 mg, $2.32 \mathrm{mmol}, 1.5$ equiv.), $\mathrm{Pd}(\mathrm{dppf}) \mathrm{Cl}_{2} \bullet \mathrm{DCM}$ (126 mg, $0.155 \mathrm{mmol}, 0.1$ equiv.), $\mathrm{Na}_{2} \mathrm{CO}_{3}$ (492 $\mathrm{mg}, 4.64 \mathrm{mmol}, 3.0$ equiv.), dioxane $(10 \mathrm{~mL})$ and water $(10 \mathrm{~mL})$ and the reaction was heated for $5 \mathrm{~h}$. The boronic acid was found to have the same $R_{\mathrm{f}}$ as the product, therefore 5 ( $250 \mathrm{mg}, 0.77 \mathrm{mmol}, 0.5$ equiv.) and $\mathrm{Pd}(\mathrm{dppf}) \mathrm{Cl}_{2} \cdot \mathrm{DCM}$ (63 $\mathrm{mg}, 0.077 \mathrm{mmol}, 0.05$ equiv.) were added and the reaction was heated for $1 \mathrm{~h}$. The crude product was purified using flash column chromatography (gradient: $20-50 \%$ EtOAc-hexane). The resulting an off-white solid was crystallised from toluene and the titled compound (135 mg, 0.48 mmol, 31\%) was collected as off-white shiny flakes. ${ }^{1} \mathbf{H}$ NMR (501 MHz, DMSO-d 6 ): $7.72-7.65(\mathrm{~m}, 3 \mathrm{H}), 7.61(\mathrm{dd}, J=8.5,0.8 \mathrm{~Hz}, 1 \mathrm{H}), 7.49(\mathrm{dd}, J=8.5,1.4 \mathrm{~Hz}, 1 \mathrm{H}), 7.09-7.02(\mathrm{~m}, 2 \mathrm{H})$, 3.81 (s, 3H). ${ }^{13}$ C NMR (126 MHz, DMSO-d $)$ ): 159.2, 141.8, 139.5, 132.3, 128.4, 121.1, 121.0, 120.2, 119.5, 114.4, 107.5, 55.2. LC-MS (ESI+): RT $=2.01-2.09 \mathrm{~min}, \mathrm{~m} / \mathrm{z}=303.1\left(\mathrm{M}+\mathrm{H}^{+}\right)$. mp: $213.2-$ 214. $1^{\circ} \mathrm{C}$. Anal. Calcd for $\mathrm{C}_{14} \mathrm{H}_{11} \mathrm{BrN}_{2} \mathrm{O}: \mathrm{C}, 55.7 ; \mathrm{H}, 3.70 ; \mathrm{N}, 9.2$. Found: $\mathrm{C}, 55.5 ; \mathrm{H}, 3.66 ; \mathrm{N}, 9.2$.

\{3-[6-(4-methoxyphenyl)-1H-indazol-3-yl]phenyl $\}$ methanaminium formate (11)

Synthesised by method A using 10 (250 mg, $0.82 \mathrm{mmol}, 1.0$ equiv.), 3-(aminomethyl)phenylboronic acid $\cdot \mathrm{HCl}$ (232 mg, $1.24 \mathrm{mmol}, 1.5$ equiv.), $\mathrm{Pd}(\mathrm{dppf}) \mathrm{Cl}_{2} \cdot \mathrm{DCM}$ (67 mg, $0.082 \mathrm{mmol}, 0.1$ equiv.), $\mathrm{Na}_{2} \mathrm{CO}_{3}$ (437 mg, $4.12 \mathrm{mmol}, 5.0$ equiv.), dioxane $(2.5 \mathrm{~mL})$ and water $(2.5 \mathrm{~mL})$ and the reaction was heated for $5 \mathrm{~h}$. The celite pad was washed with DCM-MeOH (1:1) and the work up was carried out using DCM instead of EtOAc. The crude product was purified using flash column chromatography (isocratic: 12\% 7.0 $\mathrm{M} \mathrm{NH}_{3}$ in $\mathrm{MeOH}-\mathrm{EtOAc}$ ) and a brown semi-solid was obtained. The semi-solid was further purified using RP ACC (gradient: $0-40 \% \mathrm{MeCN}-\mathrm{H}_{2} \mathrm{O}$ in $0.1 \%$ formic acid). Appropriate fractions were 
collected and reduced in vacuo to a volume of $\sim 20 \mathrm{~mL}$ until precipitation was observed. The precipitate was filtered and triturated in hot $\mathrm{MeOH}$ and the filtrate was reduced in vacuo. The resulting solid was triturated in hot EtOAc and the titled compound ( $67 \mathrm{mg}, 0.20 \mathrm{mmol}, 25 \%)$ was collected as a colourless powder in the form of a 9/10 formate salt. H NMR (500 MHz, DMSO-d $)$ ): 8.42 (br.s, 1H), 8.21 (d, $J$ $=8.5 \mathrm{~Hz}, 1 \mathrm{H}), 8.11-8.07(\mathrm{~m}, 1 \mathrm{H}), 7.96(\mathrm{dt}, J=7.7,1.4 \mathrm{~Hz}, 1 \mathrm{H}), 7.75-7.67(\mathrm{~m}, 3 \mathrm{H}), 7.52(\mathrm{t}, J=7.7$ $\mathrm{Hz}, 1 \mathrm{H}), 7.48$ (dd, $J=8.6,1.6 \mathrm{~Hz}, 1 \mathrm{H}), 7.44$ (d, $J=7.6 \mathrm{~Hz}, 1 \mathrm{H}), 7.10-7.04$ (m, 2H), 4.03 (s, 2H), 3.82 (s, 3H). ${ }^{13}$ C NMR (126 MHz, DMSO-d $)$ ): 165.2, 159.0, 142.8, 142.5, 138.9, 138.1, 133.9, 132.7, $128.9,128.2,127.5,126.4,125.7,121.2,120.5,119.0,114.4,107.3,55.2,43.5$. LC-MS (ESI+): RT = $0.5-0.5 \mathrm{~min}, \mathrm{~m} / \mathrm{z}=330.23\left(\mathrm{M}+\mathrm{H}^{+}\right)$.

\{3-[6-(4-methoxyphenyl)-1H-indazol-3-yl]phenyl $\}$ methanol (12)

Synthesised by method A using 10 ( $250 \mathrm{mg}, 0.82 \mathrm{mmol}, 1.0$ equiv.), 3-(hydroxymethyl)phenylboronic acid (188 mg, $1.24 \mathrm{mmol}, 1.5$ equiv.), $\mathrm{Pd}(\mathrm{dppf}) \mathrm{Cl}_{2} \cdot \mathrm{DCM}$ (67 mg, $0.082 \mathrm{mmol}, 0.1$ equiv.), $\mathrm{Na}_{2} \mathrm{CO}_{3}$ (262 $\mathrm{mg}, 2.47 \mathrm{mmol}, 3.0$ equiv.), dioxane $(2.5 \mathrm{~mL})$ and water $(2.5 \mathrm{~mL})$ and the reaction was heated for $4.5 \mathrm{~h}$. The crude product was purified using flash column chromatography (gradient: $60-70 \%$ EtOAc-hexane) and the resulting yellow solid was crystallised from EtOH to give the titled compound (118 mg, 0.36 mmol, 43\%) as yellow micro-granules. ${ }^{1} \mathbf{H}$ NMR (501 MHz, DMSO-d 6 ): 13.23 (br.s, $1 \mathrm{H}), 8.14-8.09(\mathrm{~m}, 1 \mathrm{H}), 8.02-7.97(\mathrm{~m}, 1 \mathrm{H}), 7.88$ (dt, $J=7.7,1.5 \mathrm{~Hz}, 1 \mathrm{H}), 7.74-7.67(\mathrm{~m}, 3 \mathrm{H}), 7.51-$ 7.45 (m, 2H), 7.35 (ddd, $J=7.6,1.9,1.1 \mathrm{~Hz}, 1 \mathrm{H}), 7.10-7.03(\mathrm{~m}, 2 \mathrm{H}), 5.29$ (t, $J=5.9 \mathrm{~Hz}, 1 \mathrm{H}), 4.63$ (d, $J=5.8 \mathrm{~Hz}, 2 \mathrm{H}), 3.82$ (s, 3H). ${ }^{13} \mathbf{C}$ NMR (126 MHz, DMSO-d 6 ): 159.0, 143.2, 143.2, 142.4, 138.1, 133.5, 132.7, 128.6, 128.2, 125.7, 125.0, 124.7, 121.1, 120.5, 119.0, 114.4, 107.3, 62.9, 55.2. LC-MS (ESI+): $\mathrm{RT}=0.6-0.6 \mathrm{~min}, \mathrm{~m} / \mathrm{z}=331.20\left(\mathrm{M}+\mathrm{H}^{+}\right) . \mathbf{m p}: 191.7-193.1{ }^{\circ} \mathrm{C}$.

3-(3-ethylphenyl)-6-(4-methoxyphenyl)-1 $H$-indazole (13)

Synthesised by method A using 10 (250 mg, $0.82 \mathrm{mmol}, 1.0$ equiv.), 3-ethylphenylboronic acid (186 mg, $1.24 \mathrm{mmol}, 1.5$ equiv.), $\mathrm{Pd}(\mathrm{dppf}) \mathrm{Cl}_{2} \cdot \mathrm{DCM}$ (67 mg, $0.082 \mathrm{mmol}, 0.1$ equiv.), $\mathrm{Na}_{2} \mathrm{CO}_{3}$ (262 mg, 2.47 mmol, 3.0 equiv.), dioxane $(2.5 \mathrm{~mL})$ and water $(2.5 \mathrm{~mL})$ and the reaction was heated for $3.5 \mathrm{~h}$. The crude product was purified using flash column chromatography (isocratic: 7:3 hexane-EtOAc). The titled compound (26 mg, $0.07 \mathrm{mmol}, 16 \%$ ) was collected as colourless waxy platelets. ${ }^{1} \mathbf{H}$ NMR (501 MHz, DMSO-d 6 ): 13.21 (br.s, 1H), 8.09 (dd, $J=8.5,1.0 \mathrm{~Hz}, 1 \mathrm{H}), 7.84$ (d, $J=1.8 \mathrm{~Hz}, 1 \mathrm{H}), 7.82$ (dt, $J=7.6,1.4 \mathrm{~Hz}, 1 \mathrm{H}), 7.73-7.67(\mathrm{~m}, 3 \mathrm{H}), 7.47$ (dd, $J=8.5,1.6 \mathrm{~Hz}, 1 \mathrm{H}), 7.44$ (t, $J=7.6 \mathrm{~Hz}, 1 \mathrm{H})$, $7.26(\mathrm{dt}, J=7.9,1.3 \mathrm{~Hz}, 1 \mathrm{H}), 7.10-7.03(\mathrm{~m}, 2 \mathrm{H}), 3.82(\mathrm{~s}, 3 \mathrm{H}), 2.73(\mathrm{q}, J=7.6 \mathrm{~Hz}, 2 \mathrm{H}), 1.27(\mathrm{t}, J=$ $7.6 \mathrm{~Hz}, 3 \mathrm{H}) .{ }^{13} \mathbf{C}$ NMR (126 MHz, DMSO-d $)$ ): 159.0, 144.3, 143.3, 142.4, 138.1, 133.7, 132.7, 128.8, 128.2, 127.2, 126.1, 124.1, 121.1, 120.5, 119.1, 114.4, 107.3, 55.2, 28.2, 15.7. LC-MS (ESI+): RT = $0.7-0.8 \mathrm{~min}, \mathrm{~m} / \mathrm{z}=329.23\left(\mathrm{M}+\mathrm{H}^{+}\right)$. 
3,6-bis(4-methoxyphenyl)- $1 H$-indazole (14)

Synthesised as a side-product and isolated in the purification 10. The product was triturated in hot EtOH decanting off the yellow solution and the remaining solid was crystallised from EtOH. The titled compound (32 mg, $0.10 \mathrm{mmol}, 3 \%$ ) was collected as off-white microneedles. ${ }^{1} \mathbf{H}$ NMR (501 MHz, DMSO-d d $) 13.10$ (s, 1H), 8.06 (dt, $J=8.6,0.7 \mathrm{~Hz}, 1 \mathrm{H}), 7.97-7.91(\mathrm{~m}, 2 \mathrm{H}), 7.73-7.66(\mathrm{~m}, 3 \mathrm{H})$, $7.45(\mathrm{dd}, J=8.5,1.6 \mathrm{~Hz}, 1 \mathrm{H}), 7.13-7.08(\mathrm{~m}, 2 \mathrm{H}), 7.08-7.04(\mathrm{~m}, 2 \mathrm{H}), 3.83(\mathrm{~s}, 3 \mathrm{H}), 3.82$ (s, 3H) ${ }^{13}$ C NMR (126 MHz, DMSO-d 6 ): 159.0, 158.9, 143.0, 142.4, 138.0, 132.7, 128.2, 127.9, 126.3, 121.0, 120.3, 118.9, 114.4, 114.3, 107.2, 55.18, 55.15. LC-MS (ESI+): RT = 2.05-2.19 min, $\mathrm{m} / \mathrm{z}=331.2\left(\mathrm{M}+\mathrm{H}^{+}\right) . \mathbf{m p}: 197.0-198.0{ }^{\circ} \mathrm{C}$.

\{3-[6-(4-hydroxyphenyl)-1H-indazol-3-yl]phenyl $\}$ methanaminium bromide (15)

Synthesised by method B using 11 (50 mg, $0.15 \mathrm{mmol}, 1.0$ equiv.), $1 \mathrm{M} \mathrm{BBr}_{3}$ in DCM (1.21 mL, $1.21 \mathrm{mmol}, 8.0$ equiv. $)$ and DCM $(5 \mathrm{~mL})$ and the reaction was stirred for $2 \mathrm{~h}$. Water $(10 \mathrm{~mL})$ was added, and the biphasic mixture was left for $16 \mathrm{~h}$. The resulting needles were filtered and dissolved in $\mathrm{MeOH}$ and reduced in vacuo to reveal the crude solid as an off-white solid. The crude solid was purified by mixed solvent crystallisation from water using iso-propanol as the anti-solvent. The titled compound ( $8 \mathrm{mg}, 0.03 \mathrm{mmol}, 17 \%$ ) was collected as a colourless powder in the form of a bromide salt. ${ }^{1} \mathbf{H}$ NMR (501 MHz, DMSO-d $)$ ): 13.30 (br.s, 1H), 9.58 (br.s, 1H), 8.30-8.19 (m, 4H), 8.15 (d, $J=1.8 \mathrm{~Hz}, 1 \mathrm{H}$ ), 8.05 (dt, $J=7.8,1.4 \mathrm{~Hz}, 1 \mathrm{H}), 7.69$ (dd, $J=1.5,0.8 \mathrm{~Hz}, 1 \mathrm{H}), 7.62-7.55(\mathrm{~m}, 3 \mathrm{H}), 7.52-7.44(\mathrm{~m}, 2 \mathrm{H})$, 6.93-6.87 (m, 2H), 4.18 (q, $J=5.9$ Hz, 2H). ${ }^{13}$ C NMR (126 MHz, DMSO-d $)$ ): 157.3, 142.51, 142.47, 138.6, 134.6, 134.2, 130.9, 129.2, 128.2, 127.0, 126.6, 121.1, 120.5, 118.8, 115.8, 107.0, 42.3, one Arq not observed. HPLC: $\mathrm{RT}=1.95 \mathrm{~min}$. HRMS (ESI+): Found: $316.1444\left(\mathrm{M}+\mathrm{H}^{+}\right), \mathrm{C}_{20} \mathrm{H}_{17} \mathrm{~N}_{3} \mathrm{O}$ requires MH 316.1444. mp: $191.2-195.8^{\circ} \mathrm{C}$.

4-\{3-[3-(hydroxymethyl)phenyl]-1H-indazol-6-yl $\}$ phenol (16)

4-\{3-[3-(bromomethyl)phenyl]-1H-indazol-6-yl $\}$ phenol* (83 mg, $0.22 \mathrm{mmol}, 1.0$ equiv.) was suspended in saturated $\mathrm{NaHCO}_{3}(3 \mathrm{~mL})$ and the reaction was refluxed for $18 \mathrm{~h}$. The mixture was diluted with DCM $(10 \mathrm{~mL})$ and $2 \mathrm{M} \mathrm{NaOH}(20 \mathrm{~mL})$ added, and the organic layer was separated. The aqueous layer was acidified to $\mathrm{pH} 1.0(2 \mathrm{M} \mathrm{HCl})$ and the solution was extracted with DCM $(20 \mathrm{~mL})$. The aqueous layer was neutralized to $\mathrm{pH} 7.0$ and the solution was extracted with DCM $(20 \mathrm{~mL})$ and the combined organic layers were reduced in vacuo and the crude product was purified by RP ACC (gradient: 0-30\% $\left.\mathrm{MeCN}-\mathrm{H}_{2} \mathrm{O}\right)$. The titled compound ( $\left.2 \mathrm{mg}, 6 \times 10^{-3} \mathrm{mmol}, 3 \%\right)$ was collected as an off-white solid.

*Compound formed as an undesired product from $\mathrm{BBr}_{3}$ deprotection of $\mathbf{1 2}$ and was not isolated. ${ }^{\mathbf{1}} \mathbf{H}$ NMR (501 MHz, DMSO-d 6 ): 13.20 (br.s, 1H), 9.60 (br.s, 1H), 8.09 (d, $J=8.6$ Hz, 1H), 7.98 (br.s, $1 \mathrm{H}), 7.87$ (d, $J=7.9 \mathrm{~Hz}, 1 \mathrm{H}), 7.66$ (br.s, 1H), 7.62-7.55 (m, 2H), 7.51-7.42 (m, 2H), 7.34 (d, $J=7.6$ $\mathrm{Hz}, 1 \mathrm{H}), 6.92-6.86(\mathrm{~m}, 2 \mathrm{H}), 5.28(\mathrm{t}, J=5.8 \mathrm{~Hz}, 1 \mathrm{H}), 4.62(\mathrm{~d}, J=5.5 \mathrm{~Hz}, 2 \mathrm{H}) .{ }^{13} \mathbf{C}$ NMR (126 MHz, DMSO-d $)$ ): 157.2, 143.2, 142.5, 131.0, 128.6, 128.2, 125.7, 125.0, 124.6, 120.9, 120.4, 118.8, 115.8, 
106.9, 62.9, three Ar-qs not observed*. HPLC: RT = $2.41 \mathrm{~min}$. HRMS (ESI+): Found: 317.1283 $\left(\mathrm{M}+\mathrm{H}^{+}\right), \mathrm{C}_{20} \mathrm{H}_{16} \mathrm{~N}_{2} \mathrm{O}_{2}$ requires $M H 317.1285$. Weak signal due to limited material.

4-[3-(3-ethylphenyl)-1H-indazol-6-yl]phenol (17)

Synthesised using method B using 13 (100 mg, $0.30 \mathrm{mmol}, 1.0$ equiv.), $1 \mathrm{M} \mathrm{BBr}_{3}$ in $\mathrm{DCM}$ (2.44 mL, $2.44 \mathrm{mmol}, 8.0$ equiv. $)$ and DCM $(5 \mathrm{~mL})$ and the reaction was stirred for $2 \mathrm{~h}$. Water $(10 \mathrm{~mL})$ was added, and the resulting precipitate was filtered, washed with water, dissolved in $\mathrm{MeOH}$, and reduced in vacuo to reveal the crude solid as an off-white solid. The crude solid was triturated in hot EtOAc to give the titled compound (13 mg, $0.04 \mathrm{mmol}, 14 \%$ ) as a colourless powder. ${ }^{1} \mathbf{H}$ NMR (501 MHz, DMSO-d 6 ): $8.07(\mathrm{~d}, J=8.6 \mathrm{~Hz}, 1 \mathrm{H}), 7.85-7.78(\mathrm{~m}, 2 \mathrm{H}), 7.66(\mathrm{~d}, J=1.5 \mathrm{~Hz}, 1 \mathrm{H}), 7.61-7.55(\mathrm{~m}, 2 \mathrm{H}), 7.47-7.40$ (m, 2H), $7.25(\mathrm{~d}, J=7.6 \mathrm{~Hz}, 1 \mathrm{H}), 6.93-6.86(\mathrm{~m}, 2 \mathrm{H}), 2.73$ (q, $J=7.6 \mathrm{~Hz}, 2 \mathrm{H}), 1.26(\mathrm{t}, J=7.6 \mathrm{~Hz}, 3 \mathrm{H})$. ${ }^{13}$ C NMR (126 MHz, DMSO-d 6 ): 157.2, 144.3, 143.2, 142.5, 138.5, 133.7, 131.0, 128.8, 128.2, 127.2, $126.0,124.1,121.0,120.5,118.9,115.8,106.9,28.2,15.7$. HPLC: RT $=3.48 \min (97 \%)$. HRMS (ESI+): Found: $315.1490\left(\mathrm{M}+\mathrm{H}^{+}\right), \mathrm{C}_{21} \mathrm{H}_{18} \mathrm{~N}_{2} \mathrm{O}$ requires $M H 315.1492$.

3,6-bis(4-hydroxyphenyl)-1 $H$-indazole (18)

Synthesised using method B using 14 (194 mg, $0.59 \mathrm{mmol}, 1.0$ equiv.), $1 \mathrm{M} \mathrm{BBr}_{3}$ in DCM (4.70 mL, $4.70 \mathrm{mmol}, 8.0$ equiv. $)$ and DCM $(15 \mathrm{~mL})$ and the reaction was stirred for $23 \mathrm{~h}$. Water $(20 \mathrm{~mL})$ was added, and the resulting precipitate was filtered and washed with DCM. The solid was dissolved in $\mathrm{MeOH}$ and reduced in vacuo to yield the crude product as a brown solid. The crude product was triturated with small amounts of cold $\mathrm{MeOH}$ and filtered to give the titled compound ( $73 \mathrm{mg}, 0.24$ mmol, 41\%) as an off-white solid. ${ }^{1} \mathbf{H}$ NMR (501 MHz, DMSO-d $\left.{ }_{6}\right): 12.98$ (s, 1H), 9.58 (s, 1H), 9.56 (s, 1H), $8.01(\mathrm{~d}, J=8.5 \mathrm{~Hz}, 1 \mathrm{H}), 7.85-7.78(\mathrm{~m}, 2 \mathrm{H}), 7.62(\mathrm{dd}, J=1.5,0.8 \mathrm{~Hz}, 1 \mathrm{H}), 7.60-7.54(\mathrm{~m}, 2 \mathrm{H})$, $7.40(\mathrm{dd}, J=8.6,1.6 \mathrm{~Hz}, 1 \mathrm{H}), 6.95-6.90$ (m, 2H), 6.90-6.86 (m, 2H). ${ }^{13}$ C NMR (126 MHz, DMSOd $)$ : $157.18,157.16,143.3,142.4,138.3,131.1,128.1,128.0,124.8,121.0,120.0,118.7,115.8,115.6$, 106.7. HPLC: $\mathrm{RT}=2.41$ min. HRMS (ESI+): Found: $303.1138\left(\mathrm{M}+\mathrm{H}^{+}\right), \mathrm{C}_{19} \mathrm{H}_{15} \mathrm{~N}_{2} \mathrm{O}_{2}$ requires $M H$ 303.1128 .

$N$-(6-(3-ethoxyphenyl)-1 $H$-indazol-3-yl)benzamide (19)

Synthesised by method $\mathrm{C}$ using 28 (176 $\mathrm{mg}, 0.38 \mathrm{mmol}, 1.0$ equiv.), TFA ( $1 \mathrm{~mL})$ and DCM ( $1 \mathrm{~mL})$ and the reaction was stirred for $1.5 \mathrm{~h}$. The crude brown solid was triturated with $\mathrm{MeOH}$ and filtered to give the titled compound as an off-white solid (45 mg, $0.10 \mathrm{mmol}, 25 \%) .{ }^{1} \mathbf{H}$ NMR (501 MHz, DMSO-d 6 ): $10.83(\mathrm{~s}, 1 \mathrm{H}), 8.12-8.07$ (m, 2H), $7.80(\mathrm{dd}, J=8.5,0.8 \mathrm{~Hz}, 1 \mathrm{H}), 7.68$ (dd, $J=1.4,0.8 \mathrm{~Hz}, 1 \mathrm{H}), 7.66-$ 7.59 (m, 1H), 7.59-7.51 (m, 2H), 7.43-7.36 (m, 2H), 7.29 (ddd, $J=7.7,1.7,1.0 \mathrm{~Hz}, 1 \mathrm{H}), 7.26-7.22$ (m, 1H), 6.95 (ddd, $J=8.2,2.5,1.0 \mathrm{~Hz}, 1 \mathrm{H}), 4.13(\mathrm{q}, J=7.0 \mathrm{~Hz}, 2 \mathrm{H}), 1.37$ (t, $J=7.0 \mathrm{~Hz}, 3 \mathrm{H})$. ${ }^{13}$ C NMR (126 MHz, DMSOd 6 ): 165.5, 159.0, 142.0, 141.7, 140.1, 138.6, 133.8, 131.8, 130.0, 128.4, 127.9, 122.4, 119.5, 119.4, 116.3, 113.6, 113.1, 107.8, 63.1, 14.7. HPLC: RT = $3.21 \mathrm{~min}$. HRMS (ESI+): Found: $380.1365\left(\mathrm{M}+\mathrm{Na}^{+}\right), \mathrm{C}_{22} \mathrm{H}_{19} \mathrm{~N}_{3} \mathrm{NaO}_{2}$ requires $M N a 380.1369$. 
$N$-benzyl-6-(3-ethoxyphenyl)-1H-indazol-3-amine (20)

Synthesised by method C using 29 ( $80 \mathrm{mg}, 0.18 \mathrm{mmol}, 1.0$ equiv.), TFA ( $0.5 \mathrm{~mL})$ and DCM $(0.5 \mathrm{~mL})$ and the reaction was stirred for $2.5 \mathrm{~h}$. The crude product was purified by flash column chromatography (gradient: 10-20\% EtOAc-hexane) to give the titled compound as a red semi-solid (18 $\mathrm{mg}, 0.04 \mathrm{mmol}$, 22\%). ${ }^{1} \mathbf{H}$ NMR (501 MHz, $\mathbf{C D C l}_{3}$ ): 7.54 (dd, $\left.J=8.3,0.8 \mathrm{~Hz}, 1 \mathrm{H}\right), 7.47-7.42$ (m, 3H), $7.38-7.30$ (m, 3H), $7.30-7.24$ (m, 2H), 7.18 (ddd, $J=7.7,1.8,1.0 \mathrm{~Hz}, 1 \mathrm{H}), 7.14$ (t, $J=2.1 \mathrm{~Hz}, 1 \mathrm{H}), 6.88$ (ddd, $J$ $=8.2,2.6,0.9 \mathrm{~Hz}, 1 \mathrm{H}), 4.64(\mathrm{~s}, 2 \mathrm{H}), 4.09(\mathrm{q}, J=7.0 \mathrm{~Hz}, 2 \mathrm{H}), 1.43(\mathrm{t}, J=7.0 \mathrm{~Hz}, 3 \mathrm{H})$. ${ }^{13}$ C NMR (126 MHz, $\left.\mathbf{C D C l}_{3}\right): 159.5,150.7,143.3,143.0,141.1,139.7,129.9,128.8,128.0,127.5$, 120.1 119.6, 119.5, 114.1, 113.6, 108.1, 63.7, 48.5, 23.5, 15.0. HPLC: RT = $2.92 \min (71 \% *)$. HRMS (ESI+): Found: $344.1757\left(\mathrm{M}+\mathrm{H}^{+}\right), \mathrm{C}_{22} \mathrm{H}_{22} \mathrm{~N}_{3} \mathrm{O}$ requires $M H$ 344.1757.*Pure at time of testing (see ${ }^{1} \mathrm{H}$ NMR), HPLC performed after degradation took place.

$N$-(6-(3-ethoxyphenyl)-1H-indazol-3-yl)cyclohexanecarboxamide (21)

Synthesised by method C using 30 (110 mg, $0.24 \mathrm{mmol}, 1.0$ equiv.), TFA (1 mL) and DCM (1 mL) and the reaction was stirred for $1.5 \mathrm{~h}$. The crude brown solid was triturated with $\mathrm{MeOH}$ and filtered to give the titled compound as a pink solid (43 mg, 0.09 mmol, 38\%). ${ }^{1} \mathbf{H}$ NMR (501 MHz, DMSO-d 6 ): 12.65 (br.s, 1H), 10.21 (br.s, 1H), 7.79 (dd, $J=8.5,0.8 \mathrm{~Hz}, 1 \mathrm{H}), 7.61$ (t, $J=1.2 \mathrm{~Hz}, 1 \mathrm{H}), 7.43-7.31$ (m, 2H), $7.29-7.23(\mathrm{~m}, 1 \mathrm{H}), 7.21(\mathrm{t}, J=2.1 \mathrm{~Hz}, 1 \mathrm{H}), 6.94(\mathrm{ddd}, J=8.2,2.5,0.9 \mathrm{~Hz}, 1 \mathrm{H}), 4.12(\mathrm{q}, J=7.0 \mathrm{~Hz}$, 2H), $1.88(\mathrm{~d}, J=12.7 \mathrm{~Hz}, 2 \mathrm{H}), 1.78(\mathrm{~d}, J=12.5 \mathrm{~Hz}, 2 \mathrm{H}), 1.67$ (d, $J=12.1 \mathrm{~Hz}, 1 \mathrm{H}), 1.48$ (qd, $J=12.2$, $3.1 \mathrm{~Hz}, 2 \mathrm{H}), 1.36$ (t, $J=7.0 \mathrm{~Hz}, 4 \mathrm{H}), 1.32-1.16$ (m, 3H). ${ }^{13}$ C NMR (126 MHz, DMSO-d $)$ ): 174.4, 159.0, 142.1, 141.6, 140.4, 138.5, 130.0, 122.7, 119.4, 119.1, 115.7, 113.5, 113.1, 107.6, 63.0, 43.8, 29.2, 25.4, 25.2, 14.7. HPLC: $\quad$ RT $=3.39$ min. HRMS (ESI+): Found: 386.1835 $\left(\mathrm{M}+\mathrm{Na}^{+}\right), \mathrm{C}_{22} \mathrm{H}_{25} \mathrm{~N}_{3} \mathrm{NaO}_{2}$ requires $M N a 386.1839$.

$N$-(cyclohexylmethyl)-6-(3-ethoxyphenyl)-1 $H$-indazol-3-amine (22)

Synthesised using method D using 26 (100 mg, 0.39 mmol, 1.0 equiv.), cyclohexane carboxaldehyde (57 $\mu \mathrm{L}, 0.47 \mathrm{mmol}, 1.2$ equiv.), glacial AcOH (1 drop), STAB (134 mg, $0.63 \mathrm{mmol}, 1.6$ equiv.) and $\operatorname{DCM}(3 \mathrm{~mL})$. Imine formation took ten minutes, and the reduction was stirred for $18 \mathrm{~h}$. The reaction mixture was added to water and the aqueous phase was extracted with DCM $(\times 3)$ and the combined organics were washed with brine, dried $\left(\mathrm{MgSO}_{4}\right)$, and reduced in vacuo to reveal a colourless oil. The crude product was purified using flash column chromatography (isocratic: $0.25 \% 7.0 \mathrm{M} \mathrm{NH}_{3}$ in $\mathrm{MeOH}-\mathrm{DCM}$ ) to give the titled compound (30 mg, $0.086 \mathrm{mmol}, 22 \%$ ) as a colourless oil that solidified upon standing. ${ }^{1}$ H NMR (501 MHz, DMSO-d $)$ ): 11.35 (s, 1H), 7.79 (d, $\left.J=8.3 \mathrm{~Hz}, 1 \mathrm{H}\right), 7.41$ (dd, $J=$ 1.6, $0.8 \mathrm{~Hz}, 1 \mathrm{H}), 7.35$ (t, $J=7.9 \mathrm{~Hz}, 1 \mathrm{H}), 7.22$ (ddd, $J=7.7,1.7,1.0 \mathrm{~Hz}, 1 \mathrm{H}), 7.20-7.15$ (m, 2H), 6.91 (ddd, $J=8.2,2.5,0.9 \mathrm{~Hz}, 1 \mathrm{H}), 5.93(\mathrm{t}, J=5.9 \mathrm{~Hz}, 1 \mathrm{H}), 4.11(\mathrm{q}, J=7.0 \mathrm{~Hz}, 2 \mathrm{H}), 3.14-3.05(\mathrm{~m}, 2 \mathrm{H})$, $1.82(\mathrm{~d}, J=12.9 \mathrm{~Hz}, 2 \mathrm{H}), 1.74-1.67(\mathrm{~m}, 3 \mathrm{H}), 1.67-1.61(\mathrm{~m}, 1 \mathrm{H}), 1.36(\mathrm{t}, J=7.0 \mathrm{~Hz}, 3 \mathrm{H}), 1.27-1.11$ (m, 3H), 1.01-0.90 (m, 2H). ${ }^{13}$ C NMR (126 MHz, DMSO-d $)$ : 158.9, 150.2, 142.5, 142.3, 138.5, 
129.9, 120.6, 119.3, 117.0, 113.3, 113.2, 112.9, 107.0, 63.0, 49.8, 37.0, 30.9, 26.3, 25.6, 14.7. HPLC: $\mathrm{RT}=3.08$ min. HRMS (ESI+): Found: $350.2240\left(\mathrm{M}+\mathrm{H}^{+}\right), \mathrm{C}_{22} \mathrm{H}_{27} \mathrm{~N}_{3} \mathrm{O}$ requires $M H 350.2232$.

6-(3-ethoxyphenyl)-1H-indazole-3-phenylcarboxamide (23)

Synthesised by method A using 33 (120 mg, $0.38 \mathrm{mmol}, 1.0$ equiv.), 3-ethoxyphenylboronic acid (95 mg, $0.57 \mathrm{mmol}, 1.5$ equiv.), $\mathrm{Pd}(\mathrm{dppf}) \mathrm{Cl}_{2} \cdot \mathrm{DCM}$ (31 mg, $0.038 \mathrm{mmol}, 0.1$ equiv.), $\mathrm{Na}_{2} \mathrm{CO}_{3}$ (121 mg, 1.14 mmol, 3.0 equiv.), dioxane $(2 \mathrm{~mL})$ and water $(2 \mathrm{~mL})$ and the reaction was heated for $1.5 \mathrm{~h}$. The crude product was purified using flash column chromatography (4:1 petrol-EtOAc) to give a brown solid that was crystallised from EtOH. The resulting brown needles were recrystallised from $\mathrm{CHCl}_{3}$ to give the titled compound (11 mg, $0.03 \mathrm{mmol}, 9 \%$ ) as pearlescent white platelets. ${ }^{1} \mathrm{H}$ NMR (501 MHz, DMSO$\left.\mathbf{d}_{6}\right): 10.31(\mathrm{~s}, 1 \mathrm{H}), 8.30-8.24(\mathrm{~m}, 1 \mathrm{H}), 7.93-7.87(\mathrm{~m}, 2 \mathrm{H}), 7.84(\mathrm{dd}, J=1.5,0.8 \mathrm{~Hz}, 1 \mathrm{H}), 7.61(\mathrm{dd}, J=$ $8.5,1.5 \mathrm{~Hz}, 1 \mathrm{H}), 7.41(\mathrm{t}, J=7.9 \mathrm{~Hz}, 1 \mathrm{H}), 7.38-7.34(\mathrm{~m}, 2 \mathrm{H}), 7.31$ (ddd, $J=7.7,1.7,1.0 \mathrm{~Hz}, 1 \mathrm{H}), 7.27$ (t, $J=2.1 \mathrm{~Hz}, 1 \mathrm{H}), 7.14-7.07(\mathrm{~m}, 1 \mathrm{H}), 6.97$ (ddd, $J=8.2,2.6,1.0 \mathrm{~Hz}, 1 \mathrm{H}), 4.14(\mathrm{q}, J=6.9 \mathrm{~Hz}, 2 \mathrm{H})$, 1.37 (t, $J=6.9 \mathrm{~Hz}, 3 \mathrm{H}) .{ }^{13} \mathbf{C}$ NMR (126 MHz, DMSO-d 6$)$ : 160.8, 159.0, 142.0, 141.7, 139.0, 138.8, 138.3, 130.1, 128.6, 123.4, 122.3, 121.9, 121.2, 120.2, 119.5, 113.8, 113.2, 108.4, 63.1, 14.7. HPLC: $\mathrm{RT}=3.65$ min. HRMS (ESI+): Found: $356.1395\left(\mathrm{M}+\mathrm{H}^{+}\right), \mathrm{C}_{22} \mathrm{H}_{19} \mathrm{~N}_{3} \mathrm{O}_{2}$ requires $M H$ 356.1404. mp: > $250{ }^{\circ} \mathrm{C}$.

3-Amino-6-bromo-1 $H$-indazole (25)

4-Bromo-2-fluorobenzonitrile (5.0 g, 25.0 mmol, 1.0 equiv.) was dissolved in ${ }^{\mathrm{n}} \mathrm{BuOH}(25 \mathrm{~mL})$ and 50$60 \% \mathrm{~N}_{2} \mathrm{H}_{2}$ in water $\left(5.20 \mathrm{~mL}, 100.0 \mathrm{mmol}, 4.0\right.$ equiv) was added and the reaction heated to $100{ }^{\circ} \mathrm{C}$ for $2 \mathrm{~h}$. The reaction mixture was allowed to cool slowly, and the resulting crystals were filtered and washed with $\mathrm{MeOH}$ to give the titled compound ( $4.17 \mathrm{~g}, 19.7 \mathrm{mmol}, 79 \%$ ) as colourless microneedles. A second batch crystallised in the filtrate overnight and was collected as off-white microneedles $(505 \mathrm{mg}, 2.38$ mmol, 10\%). ${ }^{1}$ H NMR (501 MHz, DMSO-d ${ }_{6}$ ): 11.49 (br.s, 1H), 7.63 (d, $J=8.5 \mathrm{~Hz}, 1 \mathrm{H}$ ), 7.42 (dd, $J$ $=1.6,0.6 \mathrm{~Hz}, 1 \mathrm{H}), 7.02(\mathrm{dd}, J=8.5,1.6 \mathrm{~Hz}, 1 \mathrm{H}), 5.44$ (br.s, 2H). ${ }^{13} \mathbf{C}$ NMR (126 MHz, DMSO-d 6 ): 149.3, 142.0, 122.1, 120.3, 119.8, 113.1, 111.8. LC-MS (ESI+): RT = 27.7-30.2 sec, m/z = 213.96 $\left(\mathrm{M}+\mathrm{H}^{+}\right)$.

3-Amino-6-(3-ethoxyphenyl)-1H-indazole (26)

Synthesised by method A using 25 (500 mg, $2.36 \mathrm{mmol}, 1.0$ equiv.), 3-ethoxyphenyl boronic acid (587 mg, 3.54 mmol, 1.5 equiv.), $\mathrm{Pd}(\mathrm{dppf}) \mathrm{Cl}_{2} \cdot \mathrm{DCM}$ (193 mg, $0.236 \mathrm{mmol}, 0.1$ equiv.), $\mathrm{Na}_{2} \mathrm{CO}_{3}$ (750 mg, $7.07 \mathrm{mmol}, 3.0$ equiv.), dioxane $(10 \mathrm{~mL})$ and water $(10 \mathrm{~mL})$ and the reaction was heated for $4 \mathrm{~h}$. The crude product was purified using flash column chromatography (isocratic: 50:49:1 EtOAc-hexane-7.0 $\mathrm{M} \mathrm{NH}_{3}$ in $\mathrm{MeOH}$ ) and the resulting off-white solid was crystallised from EtOAc. The titled compound (519 mg, 2.05 mmol, 43\%) was collected as shiny off-white crystals. ${ }^{1} \mathbf{H}$ NMR (501 MHz, DMSO-d ( $_{6}$ : $11.42(\mathrm{~s}, 1 \mathrm{H}), 7.74(\mathrm{dd}, J=8.3,0.9 \mathrm{~Hz}, 1 \mathrm{H}), 7.42(\mathrm{dd}, J=1.5,0.8 \mathrm{~Hz}, 1 \mathrm{H}), 7.36$ (t, $J=7.9 \mathrm{~Hz}, 1 \mathrm{H})$, $7.23(\mathrm{ddd}, J=7.7,1.7,1.0 \mathrm{~Hz}, 1 \mathrm{H}), 7.21-7.17(\mathrm{~m}, 2 \mathrm{H}), 6.91(\mathrm{ddd}, J=8.2,2.6,0.9 \mathrm{~Hz}, 1 \mathrm{H}), 5.35$ (s, 
2H), 4.11 (q, $J=6.9 \mathrm{~Hz}, 2 \mathrm{H}), 1.36$ (t, $J=7.0 \mathrm{~Hz}, 3 \mathrm{H}) .{ }^{13} \mathbf{C}$ NMR (126 MHz, DMSO-d $\left.\mathbf{6}\right): 158.9,149.1$, 142.5, 142.0, 138.3, 129.9, 120.6, 119.3, 117.2, 113.5, 113.3, 113.0, 107.1, 63.0, 14.7. LC-MS (ESI+): $\mathrm{RT}=31.3-34.2 \mathrm{sec}, \mathrm{m} / \mathrm{z}=254.15\left(\mathrm{M}+\mathrm{H}^{+}\right) . \mathbf{m p}: 185.4-186.0^{\circ} \mathrm{C}$.

Tert-butyl 3-amino-6-(3-ethoxyphenyl)-1 $H$-indazole-1-carboxylate (27)

Synthesised by method E using 27 (700 mg, 2.76 mmol, 1.0 equiv.), DMAP (101 mg, 0.83 mmol, 0.3 equiv.), di-tert-butyl dicarbonate (698 $\mu \mathrm{L}, 3.04 \mathrm{mmol}, 1.1$ equiv.) and THF (20 mL) and the reaction stirred for $2 \mathrm{~h}$. The crude product was purified using flash column chromatography (gradient: $25-40 \%$ EtOAc-hexane) to give the titled compound (667 mg, $1.89 \mathrm{mmol}, 68 \%$ ) as a yellow foamy solid. ${ }^{1} \mathbf{H}$ NMR (501 MHz, $\mathbf{C D C l}_{3}$ ): 8.30 (br.s, 1H), 7.57 (dd, $J=8.2,0.8 \mathrm{~Hz}, 1 \mathrm{H}$ ), 7.47 (dd, $J=8.2,1.5 \mathrm{~Hz}$, 1H), 7.35 (t, $J=7.9 \mathrm{~Hz}, 1 \mathrm{H}), 7.23$ (ddd, $J=7.6,1.7,0.9 \mathrm{~Hz}, 1 \mathrm{H}), 7.19$ (dd, $J=2.5,1.7 \mathrm{~Hz}, 1 \mathrm{H}), 6.91$ (ddd, $J=8.2,2.5,0.9 \mathrm{~Hz}, 1 \mathrm{H}), 4.82$ (br.s, 2H), 4.10 (q, $J=7.0 \mathrm{~Hz}, 2 \mathrm{H}), 1.70$ (s, 9H), 1.44 (t, $J=7.0$ $\mathrm{Hz}, 3 \mathrm{H}) .{ }^{13} \mathbf{C}$ NMR (126 MHz, $\left.\mathbf{C D C l}_{3}\right):$ 159.5, 151.6, 149.7, 142.9, 142.4, 141.3, 129.9, 122.6, 120.1, 119.5, 118.0, 114.0, 113.9, 113.6, 83.8, 63.6, 28.4, 15.0. LC-MS (ESI+): RT = 39.3-43.3 sec, $\mathrm{m} / \mathrm{z}=296.20\left(\mathrm{M}-{ }^{\mathrm{t}} \mathrm{Bu}\right)$.

Tert-butyl 3-benzamido-6-(3-ethoxyphenyl)-1H-indazole-1-carboxylate (28)

Synthesised using method F using 27 (152 mg, $0.43 \mathrm{mmol}, 1.0$ equiv.), freshly distilled benzoyl chloride (60 $\mu \mathrm{L}, 0.52 \mathrm{mmol}, 1.2$ equiv.), $i \operatorname{Pr}_{2} \mathrm{NEt}(150 \mu \mathrm{L}, 0.86 \mathrm{mmol}, 2.0$ equiv.) and $\mathrm{DCM}(5 \mathrm{~mL})$ and the reaction was stirred for $16 \mathrm{~h}$. The reaction mixture was reduced in vacuo to reveal the crude product as a yellow oil which was purified using flash column chromatography (gradient: 10-20\% EtOAc-hexane). The titled compound (120 mg, $0.26 \mathrm{mmol}, 61 \%$ ) was collected as a colourless oil. ${ }^{1} \mathbf{H}$ NMR (501 MHz, CDCl $)$ ): 9.28 (br.s, 1H), 8.40 (br.s, 1H), 8.29 (d, J=8.5 Hz, 1H), 8.05-7.99 (m, 2H), 7.63-7.54 (m, 2H), $7.51(\mathrm{dd}, J=8.4,7.0 \mathrm{~Hz}, 2 \mathrm{H}), 7.38(\mathrm{t}, J=7.9 \mathrm{~Hz}, 1 \mathrm{H}), 7.30-7.25(\mathrm{~m}, 1 \mathrm{H}), 7.23(\mathrm{t}$, $J=2.1 \mathrm{~Hz}, 1 \mathrm{H}), 6.94(\mathrm{ddd}, J=8.2,2.5,0.9 \mathrm{~Hz}, 1 \mathrm{H}), 4.12(\mathrm{q}, J=7.0 \mathrm{~Hz}, 2 \mathrm{H}), 1.69$ (s, 9H), $1.46(\mathrm{t}, J=$ $7.0 \mathrm{~Hz}, 3 \mathrm{H}) .{ }^{13} \mathbf{C}$ NMR (126 MHz, $\mathbf{C D C l}_{3}$ ): 165.7, 159.5, 149.1, 145.6, 143.2, 142.4, 142.0, 133.3, 132.7, 130.0, 129.0, 127.8, 124.8, 123.5, 120.2, 118.8, 114.2, 114.0, 112.9, 85.2, 63.7, 28.3, 15.0 . LC-MS (ESI+): RT $=45.3-50.1 \mathrm{sec}, \mathrm{m} / \mathrm{z}=458.27$.

Tert-butyl 3-(benzylamino)-6-(3-ethoxyphenyl)-1H-indazole-1-carboxylate (29)

Synthesised using method D using 27 (150 mg, $0.42 \mathrm{mmol}, 1.0$ equiv.), freshly distilled benzaldehyde (52 $\mu \mathrm{L}, 0.51 \mathrm{mmol}, 1.2$ equiv.), glacial AcOH (1 drop), STAB (144 mg, $0.68 \mathrm{mmol}, 1.6$ equiv.), and $\operatorname{DCM}(3 \mathrm{~mL})$. Imine formation required heating to $40^{\circ} \mathrm{C}$ and the addition of $4 \AA \mathrm{MS}$. STAB was added, and the reaction was stirred for $16 \mathrm{~h}$. The reaction mixture was reduced in vacuo to reveal a yellow solid which was triturated with EtOAc and then filtered. The filtrate was reduced in vacuo to give a yellow oil that was further purified by flash column chromatography (isocratic: 9:1 hexane-EtOAc) to give the titled compound as a colourless semi-solid (80 mg, $0.18 \mathrm{mmol}, 42 \%)$. ${ }^{1} \mathbf{H}$ NMR (501 $\mathbf{~ M H z}, \mathbf{C D C l}_{3}$ ): 8.28 (s, 1H), 7.53 (dd, $J=8.3,0.7 \mathrm{~Hz}, 1 \mathrm{H}), 7.49-7.42$ (m, 3H), 7.40-7.34 (m, 3H), 7.34-7.27 (m, 1H), 
7.26-7.21 (m, 1H), 7.19 (t, $J=2.1 \mathrm{~Hz}, 1 \mathrm{H}), 6.92(\mathrm{ddd}, J=8.3,2.6,0.9 \mathrm{~Hz}, 1 \mathrm{H}), 4.73(\mathrm{~s}, 2 \mathrm{H}), 4.11(\mathrm{q}$, $J=7.0 \mathrm{~Hz}, 2 \mathrm{H}), 1.72(\mathrm{~s}, 9 \mathrm{H}), 1.45$ (t, $J=7.0 \mathrm{~Hz}, 3 \mathrm{H}) .{ }^{13} \mathbf{C}$ NMR (126 MHz, $\left.\mathbf{C D C l}_{3}\right): 159.5,152.3$, $142.8,142.5,139.0,130.0,128.8,128.4,127.7,122.4,120.0,119.2,118.0,114.00,113.98,113.7$, 102.9, 63.7, 47.9, 28.5, 15.0, two Ar-qs not observed. LC-MS (ESI+): RT = 0.8-0.9 min, m/z = 444.31 $\left(\mathrm{M}+\mathrm{H}^{+}\right)$.

Tert-butyl 3-cyclohexaneamido-6-(3-ethoxyphenyl)-1 $H$-indazole-1-carboxylate (30)

Synthesised using method $\mathrm{F}$ using 27 (152 $\mathrm{mg}, 0.43 \mathrm{mmol}, 1.0$ equiv.), freshly distilled cyclohexanecarbonyl chloride ( $69 \mu \mathrm{L}, 0.52 \mathrm{mmol}, 1.2$ equiv.), $i \operatorname{Pr}_{2} \operatorname{NEt}(150 \mu \mathrm{L}, 0.86 \mathrm{mmol}, 2.0$ equiv.) and DCM $(5 \mathrm{~mL})$ and the reaction was stirred for $16 \mathrm{~h}$. The reaction mixture was reduced in vacuo to reveal the crude product as a yellow oil which was purified by flash column chromatography (gradient: 10-20\% EtOAc-hexane) to give the titled compound (150 mg, $0.33 \mathrm{mmol}, 75 \%$ ) as shiny off-white crystals. ${ }^{1} \mathbf{H}$ NMR (501 MHz, $\left.\mathbf{C D C l}_{3}\right): 8.34$ (s, 1H), 8.26-8.18 (m, 2H), $7.53(\mathrm{dd}, J=8.5,1.6 \mathrm{~Hz}, 1 \mathrm{H})$, 7.37 (t, $J=7.9 \mathrm{~Hz}, 1 \mathrm{H}), 7.25$ (ddd, $J=7.7,1.7,0.9 \mathrm{~Hz}, 2 \mathrm{H}), 7.20$ (dd, $J=2.5,1.7 \mathrm{~Hz}, 1 \mathrm{H}), 6.93$ (ddd, $J=8.2,2.5,0.9 \mathrm{~Hz}, 1 \mathrm{H}), 4.11(\mathrm{q}, J=7.0 \mathrm{~Hz}, 2 \mathrm{H}), 2.39$ (s, 1H), 2.08-2.00 (m, 2H), 1.86 (dt, $J=12.6$, $3.4 \mathrm{~Hz}, 2 \mathrm{H}), 1.74-1.69(\mathrm{~m}, 10 \mathrm{H}), 1.60-1.56(\mathrm{~m}, 2 \mathrm{H}), 1.45(\mathrm{t}, J=7.0 \mathrm{~Hz}, 3 \mathrm{H}), 1.36-1.25(\mathrm{~m}, 3 \mathrm{H})$. ${ }^{13}$ C NMR (126 MHz, $\mathbf{C D C l}_{3}$ ): 174.6, 159.6, 149.2, 145.5, 143.0, 142.4, 141.9, 123.0, 123.3, 120.1, 118.7, 114.2, 114.0, 112.8, 112.7, 85.1, 63.7, 45.8, 29.7, 28.4, 25.8, 25.7, 15.0. LC-MS (ESI+): RT = $47.3-50.9 \mathrm{sec}, \mathrm{m} / \mathrm{z}=464.35\left(\mathrm{M}+\mathrm{H}^{+}\right)$.

6-Bromo-1 $H$-indazole-3-carboxylic acid (32)

6-Bromoisatin (100 mg, $0.44 \mathrm{mmol}, 1.0$ equiv.) was suspended in water $(0.5 \mathrm{~mL})$ and $2 \mathrm{M} \mathrm{NaOH}(0.5$ $\mathrm{mL}$ ) was added, and the suspension was heated at $55^{\circ} \mathrm{C}$ for 30 minutes followed by stirring at $20{ }^{\circ} \mathrm{C}$ for 30 minutes. A solution of $\mathrm{NaNO}_{2}(31 \mathrm{mg}, 0.44 \mathrm{mmol}, 1.0$ equiv.) in water $(0.5 \mathrm{~mL})$ was cooled to $0{ }^{\circ} \mathrm{C}$ and added to the reaction mixture and stirred for five minutes. This solution was then added slowly over five minutes to a solution of $\mathrm{H}_{2} \mathrm{SO}_{4}(0.1 \mathrm{~mL})$ in water $(0.9 \mathrm{~mL})$ via a pipette submerged beneath the liquid surface and the reaction was maintained at $0{ }^{\circ} \mathrm{C}$ for 20 minutes. $\mathrm{SnCl}_{2} \cdot 2 \mathrm{H}_{2} \mathrm{O}(240 \mathrm{mg}, 1.06$ mmol, 2.4 equiv.) was dissolved in $\mathrm{HCl}(1 \mathrm{~mL})$ and added in one portion to the reaction and the mixture was warmed to $20^{\circ} \mathrm{C}$ and stirred for $1 \mathrm{~h}$. The resulting orange precipitate was filtered and washed with water. The crude solid was triturated with hot $\mathrm{AcOH}$, and the insoluble impurities removed via filtration and the filtrate was reduced in vacuo to give the titled compound ( $81 \mathrm{mg}, 0.34 \mathrm{mmol}, 76 \%$ ) as an orange powder. ${ }^{1}$ H NMR (400 MHz, DMSO-d $)$ ): $8.02(\mathrm{~d}, J=8.6 \mathrm{~Hz}, 1 \mathrm{H}), 7.88(\mathrm{~d}, J=1.6 \mathrm{~Hz}, 1 \mathrm{H}), 7.39$ (dd, $J=8.6,1.7 \mathrm{~Hz}, 1 \mathrm{H}) .{ }^{13} \mathbf{C}$ NMR (101 MHz, DMSO-d $\left.\mathbf{d}_{\mathbf{6}}\right)^{*}:$ 164.0, 143.2**, 137.2**, 126.0, 123.7, 121.7, 120.2, 114.3**. LC-MS (ESI+): RT $=0.5-0.5 \mathrm{~min}, \mathrm{~m} / \mathrm{z}=483.11\left(2 \mathrm{M}+\mathrm{H}^{+}\right)$.

*Compound highly insoluble, weak signals. **Peaks visible on HMBC spectra. 
6-Bromo-1 $H$-indazole-3-phenylcarboxamide (33)

Compound 32 (750 mg, $3.0 \mathrm{mmol}, 1.0$ equiv.) was dissolved in freshly distilled $\mathrm{SOCl}_{2}(3.0 \mathrm{~mL}$, $41.4 \mathrm{mmol}, 13.8$ equiv.) and refluxed for $1.5 \mathrm{~h}$. The reaction mixture was reduced in vacuo and the resulting solid dissolved in DCM $(9 \mathrm{~mL})$ and $\mathrm{Et}_{3} \mathrm{~N}(360 \mu \mathrm{L}, 3.6 \mathrm{mmol}, 1.2$ equiv.) was added and the reaction was stirred for five minutes. Aniline ( $720 \mu \mathrm{L}, 7.5 \mathrm{mmol}, 2.5$ equiv.) was added and the reaction was heated to $45{ }^{\circ} \mathrm{C}$ for $4 \mathrm{~h}$. The reaction mixture was added to $2 \mathrm{M} \mathrm{HCl}$ and the aqueous layer was extracted with DCM $(\times 3)$ and the combined organic layers were washed with $2 \mathrm{M} \mathrm{NaOH}$, brine, dried $\left(\mathrm{MgSO}_{4}\right)$, and concentrated in vacuo to reveal a crude red solid that was purified by flash column chromatography (isocratic: $0.5 \% \mathrm{MeOH}-\mathrm{DCM}$ ) to give a brown solid. The solid was crystallised from EtOAc and the titled compound (94 mg, $0.30 \mathrm{mmol}, 13 \%$ ) was collected as brown needles. ${ }^{\mathbf{1}} \mathbf{H}$ NMR (501 MHz, DMSO-d $)$ ): 10.36 (s, 1H), 8.16 (d, $J=8.6 \mathrm{~Hz}, 1 \mathrm{H}), 7.93-7.85$ (m, 3H), 7.43 (dd, $J=8.6$, $1.6 \mathrm{~Hz}, 1 \mathrm{H}), 7.39-7.31$ (m, 2H), 7.10 (tt, $J=7.4,1.2 \mathrm{~Hz}, 1 \mathrm{H}) .{ }^{13} \mathbf{C}$ NMR (126 MHz, DMSO-d 6160.5 , 142.1, 138.7, 138.6, 128.5, 125.6, 123.5, 123.3, 120.7, 120.3, 120.2, 113.5. LC-MS (ESI+): RT = 0.6$0.6 \mathrm{~min}, \mathrm{~m} / \mathrm{z}=316.05\left(\mathrm{M}+\mathrm{H}^{+}\right) . \mathbf{m p}:>250{ }^{\circ} \mathrm{C}$.

3-(\{4-[6-(4-hydroxyphenyl)-1H-indazol-3-yl]phenyl $\}$ amino)piperidin-1-ium formate (34)

Synthesised by method B using $\mathbf{S 1 6}$ (100 mg, 0.29 mmol, 1.0 equiv.), $1 \mathrm{M} \mathrm{BBr}_{3}$ in DCM (2.33 mL, $2.33 \mathrm{mmol}, 8.0$ equiv.) and DCM $(7 \mathrm{~mL})$ and the reaction was stirred for $20 \mathrm{~h}$. Water $(10 \mathrm{~mL})$ was added, and the resulting yellow precipitate was collected by filtration and washed with water. The crude solid was dissolved in $\mathrm{MeOH}$ and reduced in vacuo to reveal an off-white solid which was crystallised from EtOH to give the titled compound ( $36 \mathrm{mg}, 0.11 \mathrm{mmol}, 38 \%$ ) as a fluffy colourless solid. ${ }^{1} \mathbf{H}$ NMR (500 MHz, DMSO-d $): 12.76$ (s, 1H), 10.80 (s, 1H), 9.57 (s, 1H), 8.12-8.06 (m, 2H), 7.76 (d, $J=8.5$ $\mathrm{Hz}, 1 \mathrm{H}), 7.64-7.60(\mathrm{~m}, 1 \mathrm{H}), 7.59-7.52(\mathrm{~m}, 5 \mathrm{H}), 7.33$ (dd, $J=8.6,1.5 \mathrm{~Hz}, 1 \mathrm{H}), 6.91-6.85(\mathrm{~m}, 2 \mathrm{H})$. ${ }^{13}$ C NMR (101 MHz, DMSO-d 6 ): 165.5, 157.2, 141.9, 140.1, 138.8, 133.8, 131.8, 131.2, 128.4, 128.2, 127.9, 122.3, 119.2, 115.8, 115.7, 106.5. HPLC: RT = 2.46 min. HRMS (ESI+): Found: 330.1236 $\left(\mathrm{M}+\mathrm{H}^{+}\right), \mathrm{C}_{20} \mathrm{H}_{15} \mathrm{~N}_{3} \mathrm{O}_{2}$ requires $M H 330.1237$. mp: $>250{ }^{\circ} \mathrm{C}$.

4-[6-(4-methoxyphenyl)-1H-indazol-3-yl]aniline (35)

Synthesised by method A using 10 (500 mg, $1.65 \mathrm{mmol}, 1.0$ equiv.), 4-aminophenylboronic acid $\cdot \mathrm{HCl}$ (723 mg, 3.30 mmol, 2.0 equiv.), $\mathrm{Pd}(\mathrm{dppf}) \mathrm{Cl}_{2} \bullet \mathrm{DCM}$ (135 mg, $0.165 \mathrm{mmol}, 0.1$ equiv.), $\mathrm{Na}_{2} \mathrm{CO}_{3}$ (524 $\mathrm{mg}, 4.95 \mathrm{mmol}, 3.0$ equiv.), dioxane $(10 \mathrm{~mL})$ and water $(10 \mathrm{~mL})$ and the reaction was heated for $6 \mathrm{~h}$. The crude product was purified using column chromatography (isocratic: $2 \% \quad 7.0 \mathrm{M} \mathrm{NH}_{3}$ in $\mathrm{MeOH}-\mathrm{DCM}$ ) and an orange solid was obtained. The product was further purified using RP ACC (gradient: $0-50 \% \mathrm{MeCN}-\mathrm{H}_{2} \mathrm{O}$ ) and the resulting off-white solid was crystallised from EtOH to give the titled compound ( $33 \mathrm{mg}, 0.10 \mathrm{mmol}, 4 \%$ ) as shiny brown needles. Co-eluted fractions from the column were reduced in vacuo (151 mg, $0.48 \mathrm{mmol}, 29 \%)$ and used without further purification. ${ }^{1} \mathbf{H}$ NMR (501 MHz, DMSO-d ) $) 12.88$ (s, 1H), 8.02 (d, $J=8.5 \mathrm{~Hz}, 1 \mathrm{H}), 7.71-7.65$ (m, 4H), 7.64 (dd, $J=1.6,0.8 \mathrm{~Hz}$, $1 \mathrm{H}), 7.40(\mathrm{dd}, J=8.5,1.6 \mathrm{~Hz}, 1 \mathrm{H}), 7.09-7.02(\mathrm{~m}, 2 \mathrm{H}), 6.74-6.67(\mathrm{~m}, 2 \mathrm{H}), 5.26(\mathrm{~s}, 2 \mathrm{H}), 3.81(\mathrm{~s}, 3 \mathrm{H})$. 
${ }^{13}$ C NMR (126 MHz, DMSO-d $)$ ): 158.9, 148.5, 144.0, 142.3, 137.8, 132.8, 128.1, 127.6, 121.4, 121.3, 119.8, 118.9, 114.4, 114.0, 107.0, 55.2. LC-MS (ESI+): $\mathrm{RT}=0.5-0.6 \mathrm{~min}, \mathrm{~m} / \mathrm{z}=316.39\left(\mathrm{M}+\mathrm{H}^{+}\right)$. mp: $224.7-225.2^{\circ} \mathrm{C}$

6-(4-methoxyphenyl)-3-[4-(piperazin-1-yl)phenyl]-1 $H$-indazole (37)

Synthesised by method G using 35 (715 mg, 2.27 mmol, 1.0 equiv.), 36 (486 mg, 2.72 mmol, 1.2 equiv.), $\mathrm{K}_{2} \mathrm{CO}_{3}$ (752 mg, $5.44 \mathrm{mmol}, 2.4$ equiv.) and ${ }^{\mathrm{B}} \mathrm{BuOH}(15 \mathrm{~mL})$ and the reaction was heated for $111 \mathrm{~h}$. The reaction mixture was concentrated in vacuo to reveal a green/yellow solid. The solid was dissolved in DMSO, and the solution was decanted from the insoluble impurities. The crude product was purified by RP ACC (gradient: $0-30 \% \mathrm{MeCN}-\mathrm{H}_{2} \mathrm{O}$ in $0.1 \%$ formic acid) and a brown/orange solid (432 mg) was obtained. The product was further purified by suspending the solid in $2 \mathrm{M} \mathrm{NaOH}(20 \mathrm{~mL})$ and DCM $(40 \mathrm{~mL})$ added with small additions of $\mathrm{MeOH}$ until dissolution was observed. The aqueous layer was extracted with DCM $(2 \times 15 \mathrm{~mL})$ and the combined organic layers washed with brine $(50$ $\mathrm{mL})$, dried $\left(\mathrm{MgSO}_{4}\right)$ and reduced in vacuo to reveal a yellow solid. The crude solid was purified by column chromatography (isocratic: 7\% $7.0 \mathrm{M} \mathrm{NH}_{3}$ in $\mathrm{MeOH}-\mathrm{DCM}$ ) to give the titled compound (304 mg, 0.79 mmol, 39\%) was collected as an off-white powder. ${ }^{1}$ H NMR (501 MHz, DMSO-d 6 ): 13.02 (s, 1H), $8.05(\mathrm{~d}, J=8.5 \mathrm{~Hz}, 1 \mathrm{H}), 7.89-7.82(\mathrm{~m}, 2 \mathrm{H}), 7.72-7.65(\mathrm{~m}, 3 \mathrm{H}), 7.43(\mathrm{dd}, J=8.5,1.6 \mathrm{~Hz}, 1 \mathrm{H})$, 7.09-7.03 (m, 4H), 3.82 (s, 3H), 3.16-3.10 (m, 4H), 2.90-2.84 (m, 4H). ${ }^{13}$ C NMR (126 MHz, DMSOd6): 158.9, 151.1, 146.3, 142.4, 137.9, 132.8, 128.2, 127.3, 124.0, 121.1, 120.1, 118.9, 115.2, 114.4, 107.1, 55.2, 49.0, 45.5. LC-MS (ES): $\mathrm{RT}=0.5-0.5 \mathrm{~min}, \mathrm{~m} / \mathrm{z}=385.48\left(\mathrm{M}+\mathrm{H}^{+}\right)$.

4-\{4-[6-(4-hydroxyphenyl)-1 $H$-indazol-3-yl]phenyl $\}$ piperazin-1-ium formate (38)

Synthesised by method B using 37 (49 mg, $0.13 \mathrm{mmol}, 1.0$ equiv.), $1 \mathrm{M} \mathrm{BBr}_{3}$ in DCM (1.02 mL, $1.02 \mathrm{mmol}, 8.0$ equiv. $)$ and DCM $(5 \mathrm{~mL})$ and the reaction was stirred for $1 \mathrm{~h}$. Water $(10 \mathrm{~mL})$ was added and the resulting suspension was added to $\mathrm{MeOH}(10 \mathrm{~mL})$ and the reaction mixture was washed with DCM $(\times 3)$ and the combined organic layers were extracted with water $(\times 3)$, adding $\mathrm{MeOH}$ to aid dissolution. The aqueous layer was reduced in vacuo to reveal a brown solid which was purified by RP ACC (gradient: $0-40 \% \mathrm{MeCN}-\mathrm{H}_{2} \mathrm{O}$ in $0.1 \%$ formic acid) to give the titled compound (36 $\mathrm{mg}, 0.1$ mmol, 76\%) as a colourless solid in the form of 3/10 formate salt. ${ }^{1}$ H NMR (501 MHz, DMSO-d 6 ): 13.02 (br.s, $1 \mathrm{H}), 8.20$ (br.s, $1 \mathrm{H}), 8.03$ (d, $J=8.5 \mathrm{~Hz}, 1 \mathrm{H}), 7.92-7.86(\mathrm{~m}, 2 \mathrm{H}), 7.65-7.61$ (m, 1H), 7.60$7.54(\mathrm{~m}, 2 \mathrm{H}), 7.41(\mathrm{dd}, J=8.6,1.5 \mathrm{~Hz}, 1 \mathrm{H}), 7.15-7.08(\mathrm{~m}, 2 \mathrm{H}), 6.92-6.85(\mathrm{~m}, 2 \mathrm{H}), 3.35(\mathrm{t}, J=5.2 \mathrm{~Hz}$, 4H), $3.16(\mathrm{dd}, J=6.8,3.8 \mathrm{~Hz}, 4 \mathrm{H}) .{ }^{13}$ C NMR (126 MHz, DMSO-d 6 ): 163.6, 157.2, 149.8, 143.0, 142.5, $138.3,131.1,128.1,127.4,125.1,121.0,120.1,118.7,115.8,115.8,106.8,46.4$, 43.5. HPLC: RT = 1.82 min. HRMS (ESI+): Found: $371.1869\left(\mathrm{M}+\mathrm{H}^{+}\right), \mathrm{C}_{23} \mathrm{H}_{22} \mathrm{~N}_{4} \mathrm{O}$ requires $M H 371.1866$.

3-[2-(4-\{4-[6-(4-methoxyphenyl)-1H-indazol-3-yl]phenyl\}piperazin-1-yl)ethyl]-1,3-oxazolidin-2-one (39) 
Synthesised as a side product and isolated in the purification of $\mathbf{3 7}$. The titled compound (193 $\mathrm{mg}$, 0.39 mmol, 17\%) was collected as an off-white solid. ${ }^{1} \mathbf{H}$ NMR (501 MHz, DMSO-d $\mathbf{6}_{\mathbf{6}}$ ): 13.02 (br.s, $1 \mathrm{H}$, indazole $\mathrm{NH}), 8.05$ (d, $J=8.5 \mathrm{~Hz}, 1 \mathrm{H}, 4-\mathrm{H}), 7.86(\mathrm{~d}, J=8.6 \mathrm{~Hz}, 2 \mathrm{H}, 2$ '"'-H and 6" '-H), 7.72-7.65 (m, 3H, 2' '-H, 6' 'H and 7-H), 7.43 (dd, $J=8.5,1.6 \mathrm{~Hz}, 1 \mathrm{H}, 5-\mathrm{H}), 7.08-7.03$ (m, 4H, 3''-H, 5' '-H, 3','$\mathrm{H}$ and 5', '-H), 4.25 (dd, $J=9.0,7.0 \mathrm{~Hz}, 2 \mathrm{H}$, oxazolidinone $\left.\mathrm{OC}_{2}\right), 3.82\left(\mathrm{~s}, 3 \mathrm{H}, \underline{\mathrm{C}}_{3}\right), 3.62$ (dd, $J=9.0$, $7.1 \mathrm{~Hz}, 2 \mathrm{H}$, oxazolidinone $\mathrm{NC}_{2}$ ), $3.33\left(\mathrm{t}, J=6.4 \mathrm{~Hz}, 2 \mathrm{H}\right.$, piperazine- $\mathrm{CH}_{2} \mathrm{CH}_{2}$-oxazolidinone), 3.24 $3.19\left(\mathrm{~m}, 4 \mathrm{H}\right.$, piperazine $\left.\mathrm{C}_{2}\right), 2.60\left(\mathrm{t}, J=5.0 \mathrm{~Hz}, 4 \mathrm{H}\right.$, piperazine $\left.\mathrm{C}_{2}\right), 2.54(\mathrm{t}, J=6.2 \mathrm{~Hz}, 2 \mathrm{H}$, piperazine- $\underline{\mathrm{H}}_{2} \mathrm{CH}_{2}$-oxazolidinone). ${ }^{13} \mathbf{C}$ NMR (101 MHz, DMSO-d 6 ): $159.0 \quad$ (4’'-C), 157.9 (oxazolidinone C=O), 150.4 (1'”'-C), 143.3 (3-C), 142.4 (3'-C), 137.9 (6-C), 132.8 (1'”-C), 128.2 (2"-C and 6"-C), 127.4 (3"'-C and 5'"-C), 124.2 (4"'-C), 121.1 (4-C), 120.1 (5-C), 118.9 (7'-C), 115.3 (2"'-C and 6"'-C), 114.4 (3"'-C and 5'-C), 107.1 (7-C), 61.6 (oxazolidinone $\mathrm{OCH}_{2}$ ), 55.2 $\left(\mathrm{OCH}_{3}\right), 54.9$ (piperazine- $\mathrm{CH}_{2} \mathrm{CH}_{2}$-oxazolidinone), 52.5 (piperazine $\underline{\mathrm{C}} \mathrm{H}_{2}$ ), 48.0 (piperazine $\underline{\mathrm{CH}}_{2}$ ), 44.3 (oxazolidinone $\mathrm{NCH}_{2}$ ), 40.6 (piperazine- $\mathrm{CH}_{2} \underline{\mathrm{CH}}_{2}$-oxazolidinone). LC-MS (ESI+): $\mathrm{RT}=0.6-0.6 \mathrm{~min}$, m/z $=498.61\left(\mathrm{M}+\mathrm{H}^{+}\right) . \mathbf{I R}: v_{\max } / \mathbf{c m}^{-1}$ (solid): $3234(\mathrm{~N}-\mathrm{H}), 2939,2833,1723(\mathrm{C}=\mathrm{O}), 1608$.

4-\{4-[6-(4-hydroxyphenyl)-1H-indazol-3-yl]phenyl\}-1-[2-(2-oxo-1,3-oxazolidin-3-yl)ethyl]piperazin1-ium formate (40)

Synthesised by method B using 39 (70 mg, 0.14 mmol, 1.0 equiv.), $1 \mathrm{M} \mathrm{BBr}_{3}$ in DCM (1.13 mL, 1.13 mmol, 8.0 equiv.) and $\mathrm{DCM}(3 \mathrm{~mL})$ and the reaction was stirred for 45 minutes. $\mathrm{MeOH}(10 \mathrm{~mL})$ was added, and the reaction mixture reduced in vacuo to reveal the crude product as an orange solid. The crude product was purified by RP ACC (gradient: $0-40 \% \mathrm{MeCN}-\mathrm{H}_{2} \mathrm{O}$ in $0.1 \%$ formic acid) to give an orange glassy solid that was further purified by flash column chromatography (gradient: 2-5\% $\mathrm{MeOH}-\mathrm{DCM}$ ). The titled compound (14 mg, $0.029 \mathrm{mmol}, 21 \%)$ was collected as a colourless solid. ${ }^{1} \mathbf{H}$ NMR (501 MHz, DMSO-d ) $_{1} 12.99$ (br.s, 1H), 8.18 (br.s, 1H), 8.02 (dd, $J=8.6,0.8$ Hz, 1H), 7.89$7.82(\mathrm{~m}, 2 \mathrm{H}), 7.64-7.60(\mathrm{~m}, 1 \mathrm{H}), 7.60-7.54(\mathrm{~m}, 2 \mathrm{H}), 7.40(\mathrm{dd}, J=8.6,1.5 \mathrm{~Hz}, 1 \mathrm{H}), 7.11-7.04(\mathrm{~m}, 2 \mathrm{H})$, 6.92-6.85 (m, 2H), 4.29-4.22 (m, 2H), 3.65-3.58 (m, 2H), 3.33 (t, $J=6.4 \mathrm{~Hz}, 2 \mathrm{H}), 3.21$ (t, $J=5.0 \mathrm{~Hz}$, 4H), 2.59 (t, $J=5.0 \mathrm{~Hz}, 4 \mathrm{H}), 2.53$ (t, $J=5.7 \mathrm{~Hz}, 2 \mathrm{H}) .{ }^{13} \mathbf{C}$ NMR (101 MHz, DMSO-d 6 ): 163.4, 157.9, 157.2, 150.4, 142.5, 138.3, 131.1, 128.1, 127.3, 124.3, 121.0, 120.0, 118.7, 115.8, 115.3, 106.8, 61.6, 54.9, 52.5, 48.0, 44.3, 40.6. HPLC: RT = $1.94 \min$ (96\%). HRMS (ESI+): Found: 484.2345 $\left(\mathrm{M}+\mathrm{H}^{+}\right), \mathrm{C}_{28} \mathrm{H}_{29} \mathrm{~N}_{5} \mathrm{O}_{3}$ requires $M H 484.2343$.

4-\{4-[6-(2-fluoro-4-hydroxyphenyl)-1H-indazol-3-yl]phenyl $\}$ piperazin-1-ium formate (41) Synthesised by method B using $\mathbf{S 2 1}$ (16 mg, $0.04 \mathrm{mmol}, 1.0$ equiv.), $1 \mathrm{M} \mathrm{BBr} 3$ in DCM (0.32 mL, $0.32 \mathrm{mmol}, 8.0$ equiv. $)$ and DCM $(1 \mathrm{~mL})$ and the reaction was stirred for $1 \mathrm{~h}$. The reaction mixture was concentrated in vacuo and the resulting solid was purified by RP ACC (gradient: 20-28\% $\mathrm{MeCN}-\mathrm{H}_{2} \mathrm{O}-0.1 \%$ formic acid). Appropriate fractions were combined and concentrated in vacuo to a volume of $\sim 3 \mathrm{~mL}$ until a white precipitate had formed which was then filtered to give the titled compound (15 mg, $0.04 \mathrm{mmol}, 96 \%)$ as a white powder in the form of a formate salt. ${ }^{1} \mathbf{H}$ NMR (501 
MHz, DMSO-d $\left.{ }_{6}\right): 8.30(\mathrm{~s}, 1 \mathrm{H}), 8.05(\mathrm{~d}, J=8.5 \mathrm{~Hz}, 1 \mathrm{H}), 7.91-7.85(\mathrm{~m}, 2 \mathrm{H}), 7.59(\mathrm{~d}, J=1.8 \mathrm{~Hz}, 1 \mathrm{H})$, $7.42(\mathrm{dd}, J=9.5,8.4 \mathrm{~Hz}, 1 \mathrm{H}), 7.28(\mathrm{dt}, J=8.5,1.6 \mathrm{~Hz}, 1 \mathrm{H}), 7.12-7.06(\mathrm{~m}, 2 \mathrm{H}), 6.75(\mathrm{dd}, J=8.4,2.4$ $\mathrm{Hz}, 1 \mathrm{H}), 6.71(\mathrm{dd}, J=12.8,2.4 \mathrm{~Hz}, 1 \mathrm{H}), 3.28-3.22$ (m, 4H), 3.05-2.99 (m, 4H). ${ }^{13}$ C NMR (126 MHz, DMSO-d D): $_{164.4} 159.8(\mathrm{~d}, J=245.0 \mathrm{~Hz}), 158.6(\mathrm{~d}, J=11.8 \mathrm{~Hz}), 150.4,143.2,142.0,133.2,131.4$ (d, $J=5.3 \mathrm{~Hz}), 127.4,124.5,121.9$ (d, $J=2.6 \mathrm{~Hz}), 120.7,118.84$ (d, $J=13.4 \mathrm{~Hz}), 118.82,115.6,112.2$ (d, $J=2.7 \mathrm{~Hz}), 109.8(\mathrm{~d}, J=3.1 \mathrm{~Hz}), 103.1$ (d, $J=25.0 \mathrm{~Hz}), 47.6,44.2$. HPLC: RT = $1.50 \mathrm{~min}$. HRMS (ESI+): Found: $389.1775\left(\mathrm{M}+\mathrm{H}^{+}\right), \mathrm{C}_{23} \mathrm{H}_{21} \mathrm{FN}_{4} \mathrm{O}$ requires $M H 389.1772$.

4-\{4-[6-(3-fluoro-4-hydroxyphenyl)-1 $H$-indazol-3-yl]phenyl $\}$ piperazin-1-ium formate (42)

Synthesised by method B using S22 (33 mg, $0.082 \mathrm{mmol}, 1.0$ equiv.), $1 \mathrm{M} \mathrm{BBr} 3$ in DCM (0.65 mL, 0.65 mmol, 8.0 equiv.) and DCM $(5 \mathrm{~mL})$ and the reaction was stirred for $16 \mathrm{~h}$. The reaction mixture was reduced in vacuo and the crude product was purified by RP ACC (gradient: $0-40 \% \mathrm{MeCN}-\mathrm{H}_{2} \mathrm{O}$ in $0.1 \%$ formic acid) to give the titled compound ( $9 \mathrm{mg}, 0.022 \mathrm{mmol}, 25 \%)$ as an off-white solid in the form of a 4/5 formate salt. ${ }^{1}$ H NMR (501 MHz, DMSO-d $)$ ): 8.29 (br.s, $1 \mathrm{H}$ ), 8.04 (dd, $J=8.6,0.8 \mathrm{~Hz}$, 1H), 7.91-7.83 (m, 2H), 7.68 (dd, $J=1.5,0.8 \mathrm{~Hz}, 1 \mathrm{H}), 7.55$ (dd, $J=12.7,2.2 \mathrm{~Hz}, 1 \mathrm{H}), 7.45-7.39$ (m, 2H), 7.12-7.02 (m, 3H), 3.28-3.21 (m, 4H), 3.04-2.96 (m, 5H). ${ }^{13}$ C NMR (101 MHz, DMSO-d 6 ): 163.7, 151.3 (d, $J=240.6 \mathrm{~Hz}), 149.6,144.7$ (d, $J=12.1 \mathrm{~Hz}), 143.0,142.4,137.1$ (d, $J=1.7 \mathrm{~Hz}), 131.8$ (d, $J=6.2 \mathrm{~Hz}), 127.5,125.2,123.1(\mathrm{~d}, J=2.9 \mathrm{~Hz}), 121.1,120.1,119.0,118.2(\mathrm{~d}, J=3.3 \mathrm{~Hz}), 116.0$, $114.6(\mathrm{~d}, J=19.0 \mathrm{~Hz}), 107.3,45.6,42.8$. HPLC: $\mathrm{RT}=1.94 \mathrm{~min}(95 \%) . \mathbf{m} / \mathbf{z}(\mathbf{E S}+)$ : Found: 389.1789 $\left(\mathrm{M}+\mathrm{H}^{+}\right), \mathrm{C}_{23} \mathrm{H}_{21} \mathrm{FN}_{4} \mathrm{O}$ requires $M H 389.1772$.

1-ethyl-4-\{4-[6-(4-hydroxyphenyl)-1 $H$-indazol-3-yl]phenyl $\}$ piperazin-1-ium formate (43)

Synthesised by method B using $\mathbf{S 2 3}$ (68 mg, $0.16 \mathrm{mmol}, 1.0$ equiv.), $1 \mathrm{M} \mathrm{BBr}{ }_{3}$ in DCM (1.32 mL, 1.32 mmol, 8.0 equiv.) and DCM $(3 \mathrm{~mL})$ and the reaction was stirred for $1 \mathrm{~h}$. Water was added, and the reaction mixture was transferred to a separating funnel. $\mathrm{MeOH}-\mathrm{DCM}(1: 1)$ was added to aid dissolution and the organic layer was separated. The aqueous layer was extracted with DCM $(\times 2)$ with addition of $\mathrm{MeOH}$ to aid dissolution of precipitate in aqueous layer. The combined organic layers were dried $\left(\mathrm{MgSO}_{4}\right)$ and reduced in vacuo to reveal the crude product as a yellow solid. LC-MS analysis of the aqueous layer showed product and therefore the aqueous layer was reduced in vacuo and combined with the yellow solid. The crude product was purified by RP ACC (gradient: $0-40 \% \mathrm{MeCN}-\mathrm{H}_{2} \mathrm{O}$ in $0.1 \%$ formic acid) to give the titled compound ( $41 \mathrm{mg}, 0.10 \mathrm{mmol}, 62 \%$ ) as an off-white solid in the form of a 9/10 formate salt. ${ }^{1}$ H NMR (501 MHz, DMSO-d $)$ ): 12.98 (br.s, 1H), 8.15 (br.s, 1H), 8.02 (d, $J=8.5$ $\mathrm{Hz}, 1 \mathrm{H}), 7.86(\mathrm{~d}, J=8.4 \mathrm{~Hz}, 2 \mathrm{H}), 7.63(\mathrm{~s}, 1 \mathrm{H}), 7.57$ (d, $J=8.5 \mathrm{~Hz}, 2 \mathrm{H}), 7.40(\mathrm{dd}, J=8.6,1.5 \mathrm{~Hz}, 1 \mathrm{H})$, $7.08(\mathrm{~d}, J=8.5 \mathrm{~Hz}, 2 \mathrm{H}), 6.88(\mathrm{~d}, J=8.4 \mathrm{~Hz}, 2 \mathrm{H}), 3.24$ (t, $J=5.1 \mathrm{~Hz}, 4 \mathrm{H}), 2.59$ (t, $J=5.0 \mathrm{~Hz}, 4 \mathrm{H}), 2.45$ (q, $J=7.1 \mathrm{~Hz}, 2 \mathrm{H}), 1.07$ (t, $J=7.2 \mathrm{~Hz}, 3 \mathrm{H}) .{ }^{13} \mathbf{C}$ NMR (101 MHz, DMSO-d 6 ): 163.2, 157.2, 150.3, $143.2,142.5,138.3,131.1,128.2,127.4,124.3,121.0,120.1,118.7,115.8,115.3,106.8,52.1,51.5$, 
47.7, 11.7. HPLC: $\mathrm{RT}=1.92$ min. HRMS (ESI+): Found: $399.2174\left(\mathrm{M}+\mathrm{H}^{+}\right), \mathrm{C}_{25} \mathrm{H}_{26} \mathrm{~N}_{4} \mathrm{O}$ requires $M H$ 399.2179 .

4-[3-(4-aminophenyl)-1 $H$-indazol-6-yl]phenol (44)

Synthesised by method B using 35 (50 mg, 0.16 mmol, 1.0 equiv.), $1 \mathrm{M} \mathrm{BBr}_{3}$ in $\mathrm{DCM}(1.27 \mathrm{~mL}$, $1.27 \mathrm{mmol}, 8.0$ equiv. $)$ and $\mathrm{DCM}(5 \mathrm{~mL})$ and the reaction was stirred for $1 \mathrm{~h}$. The work up proceeded in the same manner as was outlined in the preparation of $\mathbf{4 3}$. The crude product was purified by RP ACC (gradient: $0-40 \% \mathrm{MeCN}-\mathrm{H}_{2} \mathrm{O}$ in $0.1 \%$ formic acid). Appropriate fractions were combined and reduced in vacuo to a volume of $\sim 5 \mathrm{~mL}$ and the resulting solid was filtered and washed with water to give the titled compound (11 mg, $0.04 \mathrm{mmol}, 23 \%$ ) as a fluffy colourless solid. ${ }^{1} \mathbf{H}$ NMR (501 $\mathbf{~ M H z}$, DMSO-d D) $_{6} 12.84$ (s, 1H), 9.54 (s, 1H), 7.99 (d, $\left.J=8.5 \mathrm{~Hz}, 1 \mathrm{H}\right), 7.71-7.65$ (m, 2H), 7.59 (d, $J=1.6$ $\mathrm{Hz}, 1 \mathrm{H}), 7.58-7.53(\mathrm{~m}, 2 \mathrm{H}), 7.37$ (dd, $J=8.5,1.6 \mathrm{~Hz}, 1 \mathrm{H}), 6.91-6.85(\mathrm{~m}, 2 \mathrm{H}), 6.73-6.67(\mathrm{~m}, 2 \mathrm{H}), 5.25$ (s, 2H). ${ }^{13}$ C NMR (126 MHz, DMSO-d $)$ ): 157.1, 148.5, 144.0, 142.4, 138.2, 131.2, 128.1, 127.5, 121.4, 121.2, 119.7, 118.7, 115.7, 114.0, 106.6. HPLC: RT = 1.66 min. HRMS (ESI+): Found: $302.1283\left(\mathrm{M}+\mathrm{H}^{+}\right), \mathrm{C}_{19} \mathrm{H}_{15} \mathrm{~N}_{3} \mathrm{O}$ requires $M H 302.1288$.

\section{Supporting Compounds}

3-Bromo-6-(3-ethoxy-5-fluorophenyl)-1 $H$-indazole (S1)

Synthesised by method A using 5 (500 mg, $1.55 \mathrm{mmol}, 1.0$ equiv.), 3-ethoxy-5-fluorophenylboronic acid (427 mg, $2.32 \mathrm{mmol}, 1.5$ equiv.), $\mathrm{Pd}(\mathrm{dppf}) \mathrm{Cl}_{2} \cdot \mathrm{DCM}$ (126 mg, $0.155 \mathrm{mmol}, 0.1$ equiv.), $\mathrm{Na}_{2} \mathrm{CO}_{3}$ (492 mg, $4.64 \mathrm{mmol}, 3.0$ equiv.), dioxane $(10 \mathrm{~mL})$ and water $(10 \mathrm{~mL})$ and the reaction heated was for $3 \mathrm{~h}$. The crude product was purified using column chromatography (isocratic: 1:9 EtOAc-hexane) to give a colourless solid which was crystallised from cyclohexane to give the titled compound (166 mg, 0.50 mmol, 32\%) as colourless flakes. ${ }^{1} \mathbf{H}$ NMR (501 MHz, $\mathbf{C D C l}_{3}$ ): 10.64 (br.s, $\left.1 \mathrm{H}\right), 7.69$ (dd, $J=8.4$, $0.8 \mathrm{~Hz}, 1 \mathrm{H}), 7.65(\mathrm{dd}, J=1.5,0.8 \mathrm{~Hz}, 1 \mathrm{H}), 7.44$ (dd, $J=8.5,1.4 \mathrm{~Hz}, 1 \mathrm{H}), 6.96$ (t, $J=1.9 \mathrm{~Hz}, 1 \mathrm{H}), 6.92$ (ddd, $J=$ 9.5, 2.3, $1.5 \mathrm{~Hz}, 1 \mathrm{H}), 6.64(\mathrm{dt}, J=10.6,2.3 \mathrm{~Hz}, 1 \mathrm{H}), 4.09$ (q, $J=7.0 \mathrm{~Hz}, 2 \mathrm{H}), 1.46$ (t, $J=7.0 \mathrm{~Hz}, 3 \mathrm{H})$. ${ }^{13}$ C NMR (126 MHz, CDCl$): 164.0(\mathrm{~d}, J=244.9 \mathrm{~Hz}), 160.7$ (d, $\left.J=11.6 \mathrm{~Hz}\right), 143.5$ (d, $\left.J=9.9 \mathrm{~Hz}\right), 141.8$, $140.8(\mathrm{~d}, J=2.7 \mathrm{~Hz}), 123.2,123.0,122.1,120.7,110.2$ (d, $J=2.6 \mathrm{~Hz}), 108.4,106.9$ (d, $J=22.7 \mathrm{~Hz}), 101.4(\mathrm{~d}, J$ $=25.3 \mathrm{~Hz}), 64.2$, 14.9. LC-MS (ESI+): RT $=2.11-2.25 \mathrm{~min}, \mathrm{~m} / \mathrm{z}=335.0\left(\mathrm{M}+\mathrm{H}^{+}\right) . \mathbf{m p}: 166.4-167.6{ }^{\circ} \mathrm{C}$.

Anal. Calcd for $\mathrm{C}_{15} \mathrm{H}_{12} \mathrm{BrFN}_{2} \mathrm{O}$ : C,53.8; H, 3.60; N, 8.4. Found: C, 53.8; H, 3.61; N, 8.4.

3-Bromo-6-(3-ethoxy-2-fluorophenyl)-1H-indazole (S2)

Synthesised by method A using 5 (500 mg, $1.55 \mathrm{mmol}, 1.0$ equiv.), 3-ethoxy-2-fluorophenylboronic acid (429 mg, $2.33 \mathrm{mmol}, 1.5$ equiv.), $\mathrm{Pd}(\mathrm{dppf}) \mathrm{Cl}_{2} \cdot \mathrm{DCM}$ (126 mg, $0.155 \mathrm{mmol}, 0.1$ equiv.), $\mathrm{Na}_{2} \mathrm{CO}_{3}$ (492 mg, $4.65 \mathrm{mmol}, 3.0$ equiv.), dioxane $(10 \mathrm{~mL})$ and water $(10 \mathrm{~mL})$ and the reaction heated was for $2 \mathrm{~h}$. The crude product was purified using flash column chromatography (isocratic: 3:7 EtOAc-hexane) and the resulting colourless solid was crystallised from cyclohexane to give the titled compound (239 mg, 0.72 mmol, 46\%) as colourless plates. H NMR (501 MHz, CDCl $\mathbf{~}_{3}$ ): 10.39 (br.s, 1H), 7.70 (dd, $J$ $=8.4,0.8 \mathrm{~Hz}, 1 \mathrm{H}), 7.67-7.64(\mathrm{~m}, 1 \mathrm{H}), 7.42(\mathrm{dt}, J=8.4,1.5 \mathrm{~Hz}, 1 \mathrm{H}), 7.14(\mathrm{td}, J=8.0,1.4 \mathrm{~Hz}, 1 \mathrm{H})$, 
7.07-6.97 (m, 2H), 4.18 (q, $J=7.0 \mathrm{~Hz}, 2 \mathrm{H}), 1.49$ (t, $J=7.0 \mathrm{~Hz}, 3 \mathrm{H}) .{ }^{13} \mathbf{C}$ NMR (126 MHz, $\left.\mathbf{C D C l}_{3}\right)$ : $150.1(\mathrm{~d}, J=247.7 \mathrm{~Hz}), 147.8(\mathrm{~d}, J=11.3 \mathrm{~Hz}), 141.5,136.1,129.6(\mathrm{~d}, J=11.2 \mathrm{~Hz}), 124.2(\mathrm{~d}, J=4.9$ $\mathrm{Hz}), 123.7$ (d, $J=2.4 \mathrm{~Hz}), 123.3,122.7,122.4$ (d, $J=2.1 \mathrm{~Hz}), 120.2,114.3$ (d, $J=2.0 \mathrm{~Hz}), 110.6$ (d, $J$ $=3.7 \mathrm{~Hz}), 65.3,15.0 . \mathbf{L C}-\mathbf{M S}(\mathbf{E S I}+): \mathrm{RT}=1.88-2.16 \mathrm{~min}, \mathrm{~m} / \mathrm{z}=337.5\left(\mathrm{M}+\mathrm{H}^{+}\right) . \mathbf{m p}: 148.6-150.3^{\circ} \mathrm{C}$. Anal. Calcd for $\mathrm{C}_{15} \mathrm{H}_{12} \mathrm{BrFN}_{2} \mathrm{O}$ : C, 53.6; H, 3.50; N, 8.3. Found C, 53.8; H, 3.61; N, 8.4.

\section{3,6-bis(3-ethoxy-5-fluorophenyl)-1H-indazole (S3)}

Synthesised as a side product and isolated in the purification S1. The titled compound ( $87 \mathrm{mg}, 0.22$ mmol, 14\%) was collected as a fluffy colourless solid. ${ }^{1} \mathbf{H}$ NMR (501 MHz, $\left.\mathbf{C D C l}_{3}\right): 11.15$ (s, 1H), $8.05(\mathrm{dd}, J=8.5,0.8 \mathrm{~Hz}, 1 \mathrm{H}), 7.51(\mathrm{dd}, J=1.6,0.8 \mathrm{~Hz}, 1 \mathrm{H}), 7.44(\mathrm{dd}, J=8.6,1.5 \mathrm{~Hz}, 1 \mathrm{H}), 7.36(\mathrm{t}, J=$ $1.8 \mathrm{~Hz}, 1 \mathrm{H}), 7.32$ (ddd, $J=9.3,2.3,1.3 \mathrm{~Hz}, 1 \mathrm{H}), 6.95$ (t, $J=1.9 \mathrm{~Hz}, 1 \mathrm{H}), 6.90$ (ddd, $J=9.5,2.3,1.5$ $\mathrm{Hz}, 1 \mathrm{H}), 6.68$ (dt, $J=10.6,2.3 \mathrm{~Hz}, 1 \mathrm{H}), 6.64$ (dt, $J=10.5,2.2 \mathrm{~Hz}, 1 \mathrm{H}), 4.08(\mathrm{dq}, J=13.9,7.0 \mathrm{~Hz}, 4 \mathrm{H})$, $1.47(\mathrm{t}, J=6.9 \mathrm{~Hz}, 3 \mathrm{H}), 1.42(\mathrm{t}, J=7.0 \mathrm{~Hz}, 3 \mathrm{H}) .{ }^{13} \mathbf{C} \mathbf{N M R}\left(\mathbf{1 2 6} \mathbf{M H z}, \mathbf{C D C l}_{3}\right): 164.1(\mathrm{~d}, J=244.6$ Hz), 164.0 (d, $J=244.6 \mathrm{~Hz}), 160.9$ (d, $J=11.6 \mathrm{~Hz}), 160.7$ (d, $J=11.6 \mathrm{~Hz}), 144.9$ (d, $J=3.3 \mathrm{~Hz}), 143.7$ (d, $J=9.9 \mathrm{~Hz}), 142.4,139.6(\mathrm{~d}, J=2.6 \mathrm{~Hz}), 135.8$ (d, $J=10.7 \mathrm{~Hz}), 121.9,121.4,120.6,110.1$ (d, $J=$ $2.6 \mathrm{~Hz}), 109.7$ (d, $J=2.6 \mathrm{~Hz}), 108.5,106.9,106.8,102.2(\mathrm{~d}, J=24.9 \mathrm{~Hz}), 101.2(\mathrm{~d}, J=25.0 \mathrm{~Hz}), 64.0 *$, 14.7, 14.7. HPLC: $\mathrm{RT}=3.87 \mathrm{~min}$. HRMS (ESI+): Found: $395.1577\left(\mathrm{M}+\mathrm{H}^{+}\right), \mathrm{C}_{23} \mathrm{H}_{20} \mathrm{~F}_{2} \mathrm{~N}_{2} \mathrm{O}_{2}$ requires MH 395.1566.*Two overlapping peaks.

\section{3,6-bis(3-ethoxy-2-fluorophenyl)-1 $H$-indazole (S4)}

Synthesised as a side product and isolated in the purification $\mathbf{S 2}$ to give a glassy solid. The glassy solid was dissolved in $\mathrm{Et}_{2} \mathrm{O}$ and reduced in vacuo to give the titled compound (9 $\mathrm{mg}, 0.02 \mathrm{mmol}, 2 \%$ ) as a pale purple powder. ${ }^{1} \mathbf{H}$ NMR (501 $\mathbf{~ M H z , ~} \mathbf{C D C l}_{3}$ ): 10.52 (br.s, $1 \mathrm{H}$ ), 7.93 (ddd, $J=8.5,3.3,0.8 \mathrm{~Hz}$, $1 \mathrm{H}), 7.65(\mathrm{q}, J=1.2 \mathrm{~Hz}, 1 \mathrm{H}), 7.43-7.36(\mathrm{~m}, 2 \mathrm{H}), 7.18(\mathrm{td}, J=8.0,1.4 \mathrm{~Hz}, 1 \mathrm{H}), 7.13(\mathrm{td}, J=7.9,1.4$ $\mathrm{Hz}, 1 \mathrm{H}), 7.10-7.03(\mathrm{~m}, 2 \mathrm{H}), 6.99$ (td, $J=7.9,1.7 \mathrm{~Hz}, 1 \mathrm{H}), 4.18$ (p, $J=7.0 \mathrm{~Hz}, 4 \mathrm{H}), 1.50$ (td, $J=7.0$, $2.6 \mathrm{~Hz}, 6 \mathrm{H}) .{ }^{13} \mathbf{C}$ NMR (126 MHz, $\left.\mathbf{C D C l}_{3}\right): 150.6$ (d, $\left.J=249.7 \mathrm{~Hz}\right), 150.2$ (d, $\left.J=247.7 \mathrm{~Hz}\right), 147.8^{*}(\mathrm{t}$, $J=11.4 \mathrm{~Hz}), 141.7$ (d, $J=13.2 \mathrm{~Hz}), 134.8,130.1$ (d, $J=11.1 \mathrm{~Hz}), 124.3(\mathrm{~d}, J=4.6 \mathrm{~Hz}), 124.1$ (d, $J=$ $4.8 \mathrm{~Hz}), 123.2,122.5$ (d, $J=2.1 \mathrm{~Hz}), 122.4$ (d, $J=2.9 \mathrm{~Hz}), 122.0$ (d, $J=12.2 \mathrm{~Hz}), 121.9$ (d, $J=7.5$ $\mathrm{Hz}), 121.5,115.0$ (d, $J=2.1 \mathrm{~Hz}), 114.1$ (d, $J=2.0 \mathrm{~Hz}), 110.3$ (d, $J=3.4 \mathrm{~Hz}), 65.4,65.3,15.02,15.01$. HPLC: RT $=2.99$ min. HRMS (ESI+): Found: $395.1575\left(\mathrm{M}+\mathrm{H}^{+}\right), \mathrm{C}_{23} \mathrm{H}_{21} \mathrm{~F}_{2} \mathrm{~N}_{2} \mathrm{O}_{2}$ requires $M H$ 395.1571.*Two overlapping peaks.

\{3-[6-(3-ethoxy-5-methylphenyl)-1H-indazol-3-yl]phenyl $\}$ methanaminium formate (S5)

Synthesised by method A using $\mathbf{S 1}$ (100 mg, $0.30 \mathrm{mmol}, 1.0$ equiv.), 3-(aminomethyl)phenylboronic acid $\bullet \mathrm{HCl}$ (112 mg, $0.60 \mathrm{mmol}, 2.0$ equiv.), $\mathrm{Pd}(\mathrm{dppf}) \mathrm{Cl}_{2} \cdot \mathrm{DCM}$ ( $24 \mathrm{mg}, 0.03 \mathrm{mmol}, 0.1$ equiv.), $\mathrm{Na}_{2} \mathrm{CO}_{3}$ $(158 \mathrm{mg}, 1.50 \mathrm{mmol}, 5.0$ equiv.), dioxane $(5 \mathrm{~mL})$ and water $(5 \mathrm{~mL})$ and the reaction was heated for 3 h. The crude product was purified using flash column chromatography (isocratic: 1:10:89, 7.0 $\mathrm{M} \mathrm{NH}_{3}$ in $\mathrm{MeOH}-\mathrm{MeOH}-\mathrm{EtOAc}$ ) and the resulting brown solid was further purified using preparative HPLC 
(gradient: $50-80 \% \mathrm{MeOH}-\mathrm{H}_{2} \mathrm{O}$ with $0.1 \%$ formic acid). Appropriate fractions were reduced in vacuo to $\sim 3 \mathrm{~mL}$ and the compound was left to precipitate overnight. The titled compound ( $4 \mathrm{mg}, 0.01 \mathrm{mmol}$, 4\%) was collected as a colourless solid in the form of a formate salt. ${ }^{1} \mathbf{H}$ NMR (501 MHz, DMSO-d 6 ): 8.36 (br.s, 1H), 8.22 (d, $J=8.6 \mathrm{~Hz}, 1 \mathrm{H}), 8.07$ (s, 1H), 7.95 (d, $J=7.7 \mathrm{~Hz}, 1 \mathrm{H}), 7.83$ (d, $J=1.6 \mathrm{~Hz}, 1 \mathrm{H})$, $7.56-7.49(\mathrm{~m}, 2 \mathrm{H}), 7.43(\mathrm{~d}, J=7.6 \mathrm{~Hz}, 1 \mathrm{H}), 7.17(\mathrm{dt}, J=9.9,1.9 \mathrm{~Hz}, 1 \mathrm{H}), 7.13(\mathrm{t}, J=1.9 \mathrm{~Hz}, 1 \mathrm{H}), 6.85$ (dt, $J=11.0,2.3 \mathrm{~Hz}, 1 \mathrm{H}), 4.15$ (q, $J=7.0 \mathrm{~Hz}, 2 \mathrm{H}), 4.01$ (br.s, 2H), 1.37 (t, $J=6.9 \mathrm{~Hz}, 3 \mathrm{H}$ ). ${ }^{13}$ C NMR (126 MHz, DMSO-d 6 ): 164.7, 163.4 (d, $\left.J=241.9 \mathrm{~Hz}\right), 160.3$ (d, $\left.J=12.4 \mathrm{~Hz}\right), 143.3$ (d, $J=$ $10.0 \mathrm{~Hz}), 143.0,142.1$, 139.6, 137.1, 133.7, 128.9, 127.5, 126.3, 125.6, 121.3, 120.7, 119.8, 109.6, 108.6, $106.0(\mathrm{~d}, J=22.6 \mathrm{~Hz}), 100.9(\mathrm{~d}, J=26.2 \mathrm{~Hz}), 63.7,43.8,14.5$. HPLC: $\mathrm{RT}=0.60 \mathrm{~min}$. HRMS (ESI+): Found: 384.1486 (M-formate ${ }^{+}$), $\mathrm{C}_{22} \mathrm{H}_{20} \mathrm{FN}_{3} \mathrm{NaO}$ requires $M H 384.1483$.

\{3-[6-(3-ethoxy-5-fluorophenyl)-1 $H$-indazol-3-yl]phenyl $\}$ methanol (S6)

Synthesised by method A using $\mathbf{S 1}$ (100 mg, $0.30 \mathrm{mmol}, 1.0$ equiv.), 3-(hydroxymethyl)phenylboronic acid (68 mg, $0.45 \mathrm{mmol}, 1.5$ equiv.), $\mathrm{Pd}(\mathrm{dppf}) \mathrm{Cl}_{2} \bullet \mathrm{DCM}$ ( $24 \mathrm{mg}, 0.03 \mathrm{mmol}, 0.1$ equiv.), $\mathrm{Na}_{2} \mathrm{CO}_{3}(95$ $\mathrm{mg}, 0.90 \mathrm{mmol}, 3.0$ equiv.), dioxane $(5 \mathrm{~mL})$ and water $(5 \mathrm{~mL})$ and the reaction was heated for $2 \mathrm{~h}$. The crude product was purified using flash column chromatography (isocratic: 3:2 EtOAc-hexane) to give a yellow solid which was crystallised from toluene to give the titled compound ( $34 \mathrm{mg}, 0.094 \mathrm{mmol}$, 31\%) as colourless fluffy microneedles. ${ }^{1} \mathbf{H}$ NMR (501 MHz, DMSO-d 6 ): 8.14 (dd, $J=8.6,0.8 \mathrm{~Hz}$, 1H), 7.99 (d, $J=1.9 \mathrm{~Hz}, 1 \mathrm{H}), 7.88(\mathrm{dt}, J=7.7,1.6 \mathrm{~Hz}, 1 \mathrm{H}), 7.82$ (t, $J=1.1 \mathrm{~Hz}, 1 \mathrm{H}), 7.53$ (dd, $J=8.6$, $1.6 \mathrm{~Hz}, 1 \mathrm{H}), 7.48(\mathrm{t}, J=7.6 \mathrm{~Hz}, 1 \mathrm{H}), 7.35(\mathrm{ddd}, J=7.6,1.8,1.1 \mathrm{~Hz}, 1 \mathrm{H}), 7.20-7.15$ (m, 1H), 7.15-7.11 (m, 1H), $6.85(\mathrm{dt}, J=11.0,2.3 \mathrm{~Hz}, 1 \mathrm{H}), 5.29$ (t, $J=6.0 \mathrm{~Hz}, 1 \mathrm{H}), 4.62(\mathrm{~d}, J=4.2 \mathrm{~Hz}, 2 \mathrm{H}), 4.15$ (q, $J=$ $6.9 \mathrm{~Hz}, 2 \mathrm{H}), 1.37$ (t, $J=7.0 \mathrm{~Hz}, 3 \mathrm{H}) .{ }^{13} \mathbf{C}$ NMR (126 MHz, DMSO-d $): 163.4$ (d, $\left.J=241.9 \mathrm{~Hz}\right), 160.3$ (d, $J=12.0 \mathrm{~Hz}), 143.28$ (d, $J=10.2 \mathrm{~Hz}), 143.25$ (d, $J=7.8 \mathrm{~Hz}), 142.1,137.1,133.4,128.6,125.8$, 125.0, 124.7, 121.2, 120.7, 119.8, 109.6, 108.5, 106.0 (d, $J=22.6 \mathrm{~Hz}), 100.9$ (d, $J=25.1 \mathrm{~Hz}), 63.7$, 62.9, 14.5. HPLC: $\mathrm{RT}=1.77 \mathrm{~min}$. HRMS (ESI+): Found: $363.1515\left(\mathrm{M}+\mathrm{H}^{+}\right), \mathrm{C}_{22} \mathrm{H}_{19} \mathrm{FN}_{2} \mathrm{O}_{2}$ requires MH 363.1503. mp: $171.2-171.8^{\circ} \mathrm{C}$. Anal. Calcd for $\mathrm{C}_{22} \mathrm{H}_{19} \mathrm{FN}_{2} \mathrm{O}_{2}$ : C,73.1; H, 5.30; N, 7.8. Found: C, 72.9; H, 5.28; N, 7.7.

6-(3-ethoxy-5-fluorophenyl)-3-(3-ethylphenyl)-1 $H$-indazole (S7)

Synthesised by method A using S1 (100 mg, $0.30 \mathrm{mmol}, 1.0$ equiv.), 3-ethylphenylboronic acid (67 mg, $0.45 \mathrm{mmol}, 1.5$ equiv.), $\mathrm{Pd}(\mathrm{dppf}) \mathrm{Cl}_{2} \cdot \mathrm{DCM}\left(24 \mathrm{mg}, 0.03 \mathrm{mmol}, 0.1\right.$ equiv.), $\mathrm{Na}_{2} \mathrm{CO}_{3}$ (95 mg, $0.90 \mathrm{mmol}$, 3.0 equiv.), dioxane $(5 \mathrm{~mL})$ and water $(5 \mathrm{~mL})$ and the reaction was heated for $2 \mathrm{~h}$. The crude product was purified using flash column chromatography (isocratic: 1:9 EtOAc-hexane) and the resulting colourless glassy solid was dissolved in $\mathrm{Et}_{2} \mathrm{O}$ and reduced in vacuo to give the titled compound $(28 \mathrm{mg}$, $0.078 \mathrm{mmol}, 25 \%)$ as an off-white hygroscopic foamy solid. ${ }_{-}^{1} \mathbf{H}$ NMR (501 $\mathbf{~ M H z}, \mathbf{C D C l}_{3}$ ): 11.87 (br.s, $1 \mathrm{H}), 8.05(\mathrm{dd}, J=8.5,0.8 \mathrm{~Hz}, 1 \mathrm{H}), 7.91-7.84(\mathrm{~m}, 2 \mathrm{H}), 7.49$ (t, $J=7.6 \mathrm{~Hz}, 1 \mathrm{H}), 7.42(\mathrm{dd}, J=8.5,1.5$ $\mathrm{Hz}, 1 \mathrm{H}), 7.34-7.27(\mathrm{~m}, 2 \mathrm{H}), 6.92$ (t, $J=1.9 \mathrm{~Hz}, 1 \mathrm{H}), 6.85$ (ddd, $J=9.6,2.3,1.5 \mathrm{~Hz}, 1 \mathrm{H}), 6.64$ (dt, $J=$ 10.6, $2.3 \mathrm{~Hz}, 1 \mathrm{H}), 4.10$ (q, $J=7.0 \mathrm{~Hz}, 2 \mathrm{H}), 2.73$ (q, $J=7.6 \mathrm{~Hz}, 2 \mathrm{H}), 1.48$ (t, $J=7.0 \mathrm{~Hz}, 3 \mathrm{H}), 1.26$ (t, $J$ 
$=7.6 \mathrm{~Hz}, 3 \mathrm{H}) .{ }^{13} \mathbf{C}$ NMR (126 MHz, $\left.\mathbf{C D C l}_{3}\right): 164.0(\mathrm{~d}, J=244.4 \mathrm{~Hz}), 160.6(\mathrm{~d}, J=11.5 \mathrm{~Hz}), 146.1$, 145.2, 143.8 (d, $J=9.9 \mathrm{~Hz}), 142.4,139.2$ (d, $J=2.6 \mathrm{~Hz}), 133.4,129.2,128.3,127.4,125.3,121.6$, 121.4, 120.8, 110.2 (d, $J=2.5 \mathrm{~Hz}), 108.6,106.9$ (d, $J=22.6 \mathrm{~Hz}), 101.0$ (d, $J=25.0 \mathrm{~Hz}), 64.1,29.1$, 15.6, 14.9. HPLC: $\mathrm{RT}=3.35 \mathrm{~min}(97 \%)$. HRMS (ESI+): Found: $383.1529\left(\mathrm{M}+\mathrm{Na}^{+}\right), \mathrm{C}_{23} \mathrm{H}_{21} \mathrm{FN}_{2} \mathrm{NaO}$ requires $M H 383.1530$.

\{3-[6-(3-ethoxy-2-fluorophenyl)-1H-indazol-3-yl]phenyl $\}$ methanamine (S8)

Synthesised by method A using S2 (150 mg, $0.45 \mathrm{mmol}, 1.0$ equiv.), 3-(aminomethyl)phenylboronic acid $• \mathrm{HCl}$ (126 mg, $0.67 \mathrm{mmol}, 1.5$ equiv.), $\mathrm{Pd}(\mathrm{dppf}) \mathrm{Cl}_{2} \cdot \mathrm{DCM}$ ( $37 \mathrm{mg}, 0.045 \mathrm{mmol}, 0.1$ equiv.), $\mathrm{Na}_{2} \mathrm{CO}_{3}$ (237 mg, $2.24 \mathrm{mmol}, 5.0$ equiv.), dioxane $(5 \mathrm{~mL})$ and water $(5 \mathrm{~mL})$ and the reaction was heated for 2 h. The crude product was purified using flash column chromatography (isocratic: 3:10:87 7.0 $\mathrm{M} \mathrm{NH}_{3}$ in $\mathrm{MeOH}-\mathrm{MeOH}-\mathrm{EtOAc}$ ) and the resulting brown solid was recrystallised from toluene to give the titled compound (37 mg, $0.10 \mathrm{mmol}, 23 \%$ ) as pale brown crystals. ${ }^{1}$ H NMR (501 MHz, DMSO-d 6 ): $8.18(\mathrm{dd}, J=8.5,0.8 \mathrm{~Hz}, 1 \mathrm{H}), 8.00(\mathrm{~d}, J=1.9 \mathrm{~Hz}, 1 \mathrm{H}), 7.85$ (dt, $J=7.6,1.5 \mathrm{~Hz}, 1 \mathrm{H}), 7.71-7.67$ (m, 1H), 7.46 (t, $J=7.6 \mathrm{~Hz}, 1 \mathrm{H}), 7.40-7.33(\mathrm{~m}, 2 \mathrm{H}), 7.28-7.17(\mathrm{~m}, 2 \mathrm{H}), 7.13(\mathrm{td}, J=6.8,2.0 \mathrm{~Hz}, 1 \mathrm{H}), 4.17$ (q, $J=7.0 \mathrm{~Hz}, 2 \mathrm{H}), 3.84$ (s, 2H), 1.39 (t, $J=7.0 \mathrm{~Hz}, 3 \mathrm{H}) .{ }^{13}$ C NMR (126 MHz, DMSO-d $)$ ): 148.9 (d, $J=245.5 \mathrm{~Hz}), 147.0$ (d, $J=11.1 \mathrm{~Hz}), 145.0,143.4,141.8,133.4,132.9,129.2$ (d, $J=10.6 \mathrm{~Hz}), 128.6$, 126.5, 125.4, 124.6, 124.5 (d, $J=4.7 \mathrm{~Hz}), 122.3$ (d, $J=2.6 \mathrm{~Hz}), 121.9$ (d, $J=2.2 \mathrm{~Hz}), 120.9,119.5$, 114.0, 110.6 (d, $J=3.0 \mathrm{~Hz}), 64.4,45.7,14.6$. HPLC: RT = $3.39 \mathrm{~min}$. HRMS (ESI+): Found: 362.1675 $\left(\mathrm{M}+\mathrm{H}^{+}\right), \mathrm{C}_{22} \mathrm{H}_{21} \mathrm{FN}_{3} \mathrm{O}$ requires $M H 362.1669$. mp: $164.9-165.3{ }^{\circ} \mathrm{C}$.

\{3-[6-(3-ethoxy-2-fluorophenyl)-1 $H$-indazol-3-yl]phenyl $\}$ methanol (S9)

Synthesised by method A using $\mathbf{S 2}$ (150 mg, $0.45 \mathrm{mmol}, 1.0$ equiv.), 3-hydroxymethylphenylboronic acid (102 mg, $0.68 \mathrm{mmol}, 1.5$ equiv.), $\mathrm{Pd}(\mathrm{dppf}) \mathrm{Cl}_{2} \cdot \mathrm{DCM}$ (37 mg, $0.045 \mathrm{mmol}, 0.1$ equiv.), $\mathrm{Na}_{2} \mathrm{CO}_{3}$ (142 mg, $1.34 \mathrm{mmol}, 3.0$ equiv.), dioxane $(5 \mathrm{~mL})$ and water $(5 \mathrm{~mL})$ and the reaction was heated for 1 h. The crude product was purified using flash column chromatography (gradient: 50-60\% EtOAc-hexane) and the resulting off-white solid was triturated with DCM and filtered. The solid was crystallised from propan-2-ol to give the titled compound (26 mg, $0.07 \mathrm{mmol}, 16 \%$ ) as colourless crystals. ${ }_{-}^{1}$ H NMR (501 MHz, DMSO-d 6 ): 8.16 (dd, $\left.J=8.6,0.8 \mathrm{~Hz}, 1 \mathrm{H}\right), 8.02-7.98$ (m, 1H), 7.89 (dt, $J=7.7,1.5 \mathrm{~Hz}, 1 \mathrm{H}), 7.72-7.67(\mathrm{~m}, 1 \mathrm{H}), 7.48(\mathrm{t}, J=7.6 \mathrm{~Hz}, 1 \mathrm{H}), 7.36$ (ddt, $J=7.9,4.6,1.3 \mathrm{~Hz}, 2 \mathrm{H})$, 7.27-7.17 (m, 2H), 7.17-7.10 (m, 1H), 5.29 (t, $J=5.9 \mathrm{~Hz}, 1 \mathrm{H}), 4.62(\mathrm{~d}, J=5.8 \mathrm{~Hz}, 2 \mathrm{H}), 4.17$ (q, $J=$ $7.0 \mathrm{~Hz}, 2 \mathrm{H}), 1.39$ (t, $J=7.0 \mathrm{~Hz}, 3 \mathrm{H}) .{ }^{13} \mathbf{C}$ NMR (126 MHz, DMSO-d $\left.\mathbf{6}\right): 148.9$ (d, $\left.J=245.8 \mathrm{~Hz}\right), 147.0$ (d, $J=10.9 \mathrm{~Hz}), 143.3,143.2,141.7,133.4,132.9,129.2$ (d, $J=10.9 \mathrm{~Hz}), 128.6,125.8,125.0,124.7$, $124.5(\mathrm{~d}, J=4.7 \mathrm{~Hz}), 122.3$ (d, $J=2.4 \mathrm{~Hz}), 121.9$ (d, $J=1.9 \mathrm{~Hz}), 120.8,119.5,114.0,110.6$ (d, $J=3.2$ Hz), 64.4, 62.9, 14.6. HPLC: $\mathrm{RT}=3.81 \mathrm{~min}$. HRMS (ESI+): Found: $363.1513\left(\mathrm{M}+\mathrm{H}^{+}\right), \mathrm{C}_{22} \mathrm{H}_{20} \mathrm{FN}_{2} \mathrm{O}_{2}$ requires $M H 363.1509$. mp: $190.3-192.5^{\circ} \mathrm{C}$. 
6-(3-ethoxy-2-fluorophenyl)-3-(3-ethylphenyl)-1 $H$-indazole (S10)

Synthesised by method A using $\mathbf{S 2}$ (110 mg, $0.33 \mathrm{mmol}, 1.0$ equiv.), 3-ethylphenylboronic acid (74 $\mathrm{mg}$, $0.49 \mathrm{mmol}, 1.5$ equiv.), $\mathrm{Pd}(\mathrm{dppf}) \mathrm{Cl}_{2} \cdot \mathrm{DCM}$ ( $27 \mathrm{mg}, 0.033 \mathrm{mmol}, 0.1$ equiv.), $\mathrm{Na}_{2} \mathrm{CO}_{3}$ (104 mg, $0.98 \mathrm{mmol}, 3.0$ equiv. $)$, dioxane $(5 \mathrm{~mL})$ and water $(5 \mathrm{~mL})$ and the reaction was heated for $2 \mathrm{~h}$. The crude product was purified using flash column chromatography (isocratic: 1:4 EtOAc-hexane) and the resulting glassy solid was dissolved in $\mathrm{Et}_{2} \mathrm{O}$ and reduced in vacuo to give the titled compound $(37 \mathrm{mg}$, $0.10 \mathrm{mmol}, 31 \%$ ) as a colourless foamy solid. ${ }^{1} \mathbf{H}$ NMR (501 $\mathbf{~ M H z}, \mathbf{C D C l}_{3}$ ): 10.59 (s, 1H), 8.07 (dd, $J$ $=8.5,0.8 \mathrm{~Hz}, 1 \mathrm{H}), 7.88-7.85(\mathrm{~m}, 1 \mathrm{H}), 7.85-7.80(\mathrm{~m}, 1 \mathrm{H}), 7.62-7.58(\mathrm{~m}, 1 \mathrm{H}), 7.45(\mathrm{t}, J=7.6 \mathrm{~Hz}, 1 \mathrm{H})$, $7.42(\mathrm{dt}, J=8.5,1.5 \mathrm{~Hz}, 1 \mathrm{H}), 7.30-7.24(\mathrm{~m}, 2 \mathrm{H}), 7.14(\mathrm{td}, J=8.0,1.4 \mathrm{~Hz}, 1 \mathrm{H}), 7.08-6.96(\mathrm{~m}, 2 \mathrm{H})$, 4.18 (q, $J=7.0 \mathrm{~Hz}, 2 \mathrm{H}), 2.76(\mathrm{q}, J=7.6 \mathrm{~Hz}, 2 \mathrm{H}), 1.50(\mathrm{t}, J=7.0 \mathrm{~Hz}, 3 \mathrm{H}), 1.31$ (t, $J=7.6 \mathrm{~Hz}$, 3H). ${ }^{13}$ C NMR (126 MHz, CDCl $): 150.2$ (d, $\left.J=247.5 \mathrm{~Hz}\right), 147.7$ (d, $\left.J=11.4 \mathrm{~Hz}\right), 146.2,145.1,142.1$, 134.7, 133.5, 130.0 (d, $J=11.3 \mathrm{~Hz}), 129.0,128.0,127.2,125.1,124.1$ (d, $J=4.8 \mathrm{~Hz}), 123.2$ (d, $J=2.5$ Hz), $122.5(\mathrm{~d}, J=2.2 \mathrm{~Hz}), 121.2,120.6,114.1,110.5(\mathrm{~d}, J=3.3 \mathrm{~Hz}), 65.3,29.1,15.7,15.0$. HPLC: $\mathrm{RT}=1.49$ min. HRMS (ESI+): Found: $361.1710\left(\mathrm{M}+\mathrm{H}^{+}\right), \mathrm{C}_{23} \mathrm{H}_{22} \mathrm{FN}_{2} \mathrm{O}$ requires $M H 361.1716$.

Tert-butyl 3-(N-benzoylbenzamido)-6-(3-ethoxyphenyl)-1 $H$-indazole-1-carboxylate (S12)

Synthesised as a side product and isolated in the purification of $\mathbf{2 8}$ to give a colourless semi-solid. The colourless solid was dissolved in $\mathrm{MeOH}$ and reduced in vacuo to give the titled compound (45 $\mathrm{mg}$, 0.08 mmol, 19\%) as a white solid. ${ }^{1} \mathbf{H}$ NMR (501 $\left.\mathbf{~ M H z}, \mathbf{C D C l}_{3}\right): 8.35$ (t, $\left.J=1.1 \mathrm{~Hz}, 1 \mathrm{H}\right), 7.89-7.83$ (m, 4H), $7.56(\mathrm{qd}, J=8.4,1.1 \mathrm{~Hz}, 2 \mathrm{H}), 7.49$ (ddt, $J=8.7,7.1,1.3 \mathrm{~Hz}, 2 \mathrm{H}), 7.40-7.34(\mathrm{~m}, 5 \mathrm{H}), 7.21$ (ddd, $J=7.7,1.7,0.9 \mathrm{~Hz}, 1 \mathrm{H}), 7.17(\mathrm{dd}, J=2.5,1.7 \mathrm{~Hz}, 1 \mathrm{H}), 6.93(\mathrm{ddd}, J=8.3,2.6,0.9 \mathrm{~Hz}, 1 \mathrm{H}), 4.10$ (q, $J=7.0 \mathrm{~Hz}, 2 \mathrm{H}), 1.45$ (t, $J=7.0 \mathrm{~Hz}, 3 \mathrm{H}) .{ }^{13} \mathbf{C} \mathbf{N M R}\left(\mathbf{1 2 6} \mathbf{M H z}, \mathbf{C D C l}_{3}\right): 172.2,159.6,148.8,146.1$, 143.1, 142.2, 141.8, 134.1, 132.9, 130.1, 129.4, 128.8, 124.4, 120.4, 120.1, 119.8, 114.2, 114.1, 113.8, 85.3, 63.7, 28.2, 15.0. LC-MS (ESI+): $\mathrm{RT}=48.3-54.3 \mathrm{sec}, \mathrm{m} / \mathrm{z}=562.32\left(\mathrm{M}+\mathrm{H}^{+}\right)$.

3-(N-benzoylbenzamido)-6-(3-ethoxyphenyl)-1H-indazol-2-ium trifluoroacetate (S13)

Synthesised by method C using S12 (95 mg, $0.17 \mathrm{mmol}, 1.0$ equiv.), TFA (1 mL) and DCM (1 mL) and the reaction was stirred for 45 minutes. The crude product was purified by flash column chromatography (isocratic: 1:1 EtOAc-hexane) to give the titled compound (45 $\mathrm{mg}, 0.08 \mathrm{mmol}, 46 \%$ ) as a colourless gummy solid. ${ }^{1} \mathbf{H}$ NMR (501 MHz, $\mathbf{C D C l}_{3}$ ): 10.23 (br.s, 1H), 7.88-7.82 (m, 4H), 7.57 (dd, $J=8.4,0.8$ $\mathrm{Hz}, 1 \mathrm{H}), 7.48-7.42(\mathrm{~m}, 2 \mathrm{H}), 7.39$ (t, $J=1.1 \mathrm{~Hz}, 1 \mathrm{H}), 7.37-7.29$ (m, 6H), 7.08 (ddd, $J=7.6,1.7,0.9$ $\mathrm{Hz}, 1 \mathrm{H}), 7.05(\mathrm{dd}, J=2.5,1.6 \mathrm{~Hz}, 1 \mathrm{H}), 6.89(\mathrm{ddd}, J=8.3,2.5,0.9 \mathrm{~Hz}, 1 \mathrm{H}), 4.06(\mathrm{q}, J=7.0 \mathrm{~Hz}, 2 \mathrm{H})$, $1.43(\mathrm{t}, J=7.0 \mathrm{~Hz}, 3 \mathrm{H}) .{ }^{13} \mathbf{C}$ NMR (101 $\left.\mathbf{~ M H z}, \mathbf{C D C l}_{3}\right): 172.6,159.5,142.4,134.3,132.8,130.9,130.0$, 129.3, 129.1, 128.8, 128.2, 127.8, 122.6, 120.1, 117.4, 114.1, 113.8, 108.8, 63.7, 15.0. HPLC: $\mathrm{RT}=3.89 \min (84 \%)^{*}$. HRMS (ES+): Found: $484.1630\left(\mathrm{M}+\mathrm{Na}^{+}\right), \mathrm{C}_{29} \mathrm{H}_{23} \mathrm{~N}_{3} \mathrm{NaO}_{3}$ requires $M N a$ 484.1632.*Pure at time of biological evaluation ( see $^{1} \mathrm{H}$ NMR), HPLC performed after degradation took place. 
Tert-butyl 3-amino-6-bromo-1 $H$-indazole-1-carboxylate (S14)

Synthesised by method E using 25 (2.28 g, 10.8 mmol, 1.0 equiv.), DMAP (395 mg, 3.23 mmol, 0.3 equiv.), di-tert-butyl dicarbonate ( $2.97 \mathrm{~mL}, 12.9 \mathrm{mmol}, 1.2$ equiv.) and THF (40 mL) and the reaction was stirred for $1 \mathrm{~h}$. The crude product was purified by flash column chromatography (gradient: 20-50\% EtOAc-hexane) and the resulting off-white solid was crystallised from iso-propanol to give the titled compound $(1.36 \mathrm{~g}, 4.36 \mathrm{mmol}, 40 \%)$ as colourless granules. The filtrate was reduced in vacuo to give a colourless solid (1.30 g, $4.16 \mathrm{mmol}, 39 \%)$ which was used without further purification. ${ }^{1} \mathbf{H}$ NMR (500 MHz, DMSO-d ) $_{\text {) }} 8.12$ (br.s, $\left.1 \mathrm{H}\right), 7.80$ (dd, $\left.J=8.3,0.6 \mathrm{~Hz}, 1 \mathrm{H}\right), 7.46$ (dd, $J=8.4,1.7 \mathrm{~Hz}$, 1H), 6.41 (s, 2H), 1.58 (s, 9H). ${ }^{13}$ C NMR (125 MHz, DMSO-d 6 ): 152.1, 140.6, 125.5, 122.6, 122.5, 118.4, 116.7, 104.5, 82.9, 27.8. LC-MS (ESI+): $\mathrm{RT}=0.6-0.7 \mathrm{~min}, \mathrm{~m} / \mathrm{z}=257.97\left(\mathrm{M}-{ }^{\mathrm{t}} \mathrm{Bu}+\mathrm{H}^{+}\right)$. $\mathbf{m p}$ : $167.5-168.3^{\circ} \mathrm{C}$.

Tert-butyl 3-benzamido-6-bromo-1 $H$-indazole-1-carboxylate (S15)

Synthesised by method F using $\mathbf{S 1 4}$ (1.0 g, $3.20 \mathrm{mmol}, 1.0$ equiv.), freshly distilled benzoyl chloride (446 $\mu \mathrm{L}, 3.84 \mathrm{mmol}, 1.2$ equiv.), $i \operatorname{Pr}_{2} \operatorname{NEt}(1.12 \mathrm{~mL}, 6.41 \mathrm{mmol}, 2.0$ equiv.) and $\mathrm{DCM}(20 \mathrm{~mL})$ and the reaction was stirred for $20 \mathrm{~h}$. The crude product was purified by flash column chromatography (gradient: 5-10\% EtOAc-hexane then flush with 1:1 EtOAc-hexane) to give the titled compound (592 mg, 1.42 mmol, 44\%) as an off-white glassy solid. ${ }^{1} \mathbf{H}$ NMR (501 MHz, $\mathbf{C D C l}_{3}$ ): 8.89 (br.s, 1H), 8.38 (br.s, 1H), $8.17(\mathrm{dd}, J=8.7,0.6 \mathrm{~Hz}, 1 \mathrm{H}), 7.99-7.93(\mathrm{~m}, 2 \mathrm{H}), 7.64-7.57$ (m, 1H), 7.55-7.49 (m, 2H), 7.45 (dd, $J=$ 8.7, $1.7 \mathrm{~Hz}, 1 \mathrm{H}), 1.70$ (s, 9H). ${ }^{13} \mathbf{C}$ NMR (126 MHz, $\left.\mathbf{C D C l}_{3}\right)$ : 165.6, 148.8, 145.4, 133.1, 132.9, 129.1, 127.7, 127.2, 125.9, 124.7, 118.3, 117.7, 105.1, 85.8, 28.3. LC-MS (ESI+): RT = 0.7-0.8 min, $\mathrm{m} / \mathrm{z}=362.07\left(\mathrm{M}-{ }^{\mathrm{t}} \mathrm{Bu}+\mathrm{Br}^{81+}\right)$.

$N$-[6-(4-methoxyphenyl)-1 $H$-indazol-3-yl]benzamide (S16)

Synthesised by method A using $\mathbf{S 1 5}$ (229 mg, $0.55 \mathrm{mmol}, 1.0$ equiv.), 4-methoxyphenylboronic acid (125 mg, $0.82 \mathrm{mmol}, 1.5$ equiv.), $\mathrm{Pd}(\mathrm{dppf}) \mathrm{Cl}_{2} \cdot \mathrm{DCM}$ (45 mg, $0.055 \mathrm{mmol}, 0.1$ equiv.), $\mathrm{Na}_{2} \mathrm{CO}_{3}$ (175 $\mathrm{mg}, 1.65 \mathrm{mmol}, 3.0$ equiv.), dioxane $(2 \mathrm{~mL})$ and water $(2 \mathrm{~mL})$ and the reaction was heated for $3 \mathrm{~h}$. The crude product was purified by flash column chromatography (gradient: 50-60\% EtOAc-hexane) and the resulting solid was crystallised from propan-2-ol to give the titled compound ( $94 \mathrm{mg}, 0.27 \mathrm{mmol}$, $50 \%$ ) as colourless microneedles. The filtrate was reduced in vacuo to reveal an off-white solid (55 mg, 0.16 mmol, 29\%) which was used without further purification. ${ }^{1}$ H NMR (501 MHz, DMSO-d 6 ): 12.79 (s, 1H), $10.81(\mathrm{~s}, 1 \mathrm{H}), 8.12-8.07$ (m, 2H), 7.79 (dd, $J=8.7,0.9 \mathrm{~Hz}, 1 \mathrm{H}), 7.72-7.65$ (m, 2H), 7.65-7.58 $(\mathrm{m}, 2 \mathrm{H}), 7.58-7.51(\mathrm{~m}, 2 \mathrm{H}), 7.36(\mathrm{dd}, J=8.6,1.5 \mathrm{~Hz}, 1 \mathrm{H}), 7.09-7.02(\mathrm{~m}, 2 \mathrm{H}), 3.81$ (s, 3H). ${ }^{13}$ C NMR (126 MHz, DMSO-d $)$ ): 165.5, 159.0, 141.9, 140.1, 138.4, 133.8, 132.8, 131.8, 128.4, 128.2, 127.9, 122.4, 119.2, 115.9, 114.4, 106.9, 104.5, 55.2. LC-MS (ES): RT = 0.6-0.6 min, $\mathrm{m} / \mathrm{z}=344.20\left(\mathrm{M}+\mathrm{H}^{+}\right) . \mathbf{m p}: 213.5-215.0{ }^{\circ} \mathrm{C}$. 
3-Bromo-6-(2-fluoro-4-methoxyphenyl)-1 $H$-indazole (S17)

Synthesised by method A using 5 (750 mg, $2.3 \mathrm{mmol}, 1.0$ equiv.), 2-fluoro-4-methoxyphenylboronic acid (395 mg, $2.32 \mathrm{mmol}, 1.0$ equiv.), $\mathrm{Pd}(\mathrm{dppf}) \mathrm{Cl}_{2} \cdot \mathrm{DCM}$ (190 mg, $0.23 \mathrm{mmol}, 0.1$ equiv.), $\mathrm{Na}_{2} \mathrm{CO}_{3}$ (738 mg, $7.0 \mathrm{mmol}, 6.0$ equiv.), dioxane $(10 \mathrm{~mL})$ and water $(10 \mathrm{~mL})$ and the reaction was heated for 6 h. The crude product was purified using flash column chromatography (gradient: 20-30\% EtOAc-petrol) to give the titled compound (182 $\mathrm{mg}, 0.57 \mathrm{mmol}, 25 \%)$ as colourless microcrystals. ${ }^{1} \mathbf{H}$ NMR (501 MHz, DMSO-d $)$ ): 13.46 (s, 1H), 7.66-7.61 (m, 2H), 7.54 (t, $J=9.0 \mathrm{~Hz}, 1 \mathrm{H}), 7.36$ (dt, $J=$ $8.5,1.6 \mathrm{~Hz}, 1 \mathrm{H}), 6.98(\mathrm{dd}, J=13.0,2.5 \mathrm{~Hz}, 1 \mathrm{H}), 6.92(\mathrm{dd}, J=8.6,2.6 \mathrm{~Hz}, 1 \mathrm{H}), 3.83(\mathrm{~s}, 3 \mathrm{H}) .{ }^{13} \mathbf{C} \mathbf{N M R}$ (126 MHz, DMSO-d $)$ ): 160.4 (d, $J=11.3 \mathrm{~Hz}), 159.7$ (d, $J=246.0 \mathrm{~Hz}), 141.2,134.4,131.5$ (d, $J=4.9$ $\mathrm{Hz}), 122.8(\mathrm{~d}, J=2.7 \mathrm{~Hz}), 121.2,120.2,120.1$ (d, $J=13.3 \mathrm{~Hz}), 119.2,111.0(\mathrm{~d}, J=2.9 \mathrm{~Hz}), 110.3$ (d, $J=3.5 \mathrm{~Hz}), 102.1(\mathrm{~d}, J=26.5 \mathrm{~Hz}), 55.7$. LC-MS (ES): $\mathrm{RT}=0.6-0.7 \mathrm{~min}, \mathrm{~m} / \mathrm{z}=321.27\left(\mathrm{M}+\mathrm{H}^{+}\right)$.

3-Bromo-6-(3-fluoro-4-methoxyphenyl)-1 $H$-indazole (S18)

Synthesised by method A using 5 (750 mg, $2.32 \mathrm{mmol}, 1.0$ equiv.), 3-fluoro-4-methoxyphenylboronic acid (395 mg, $2.32 \mathrm{mmol}, 1.0$ equiv.), $\mathrm{Pd}(\mathrm{dppf}) \mathrm{Cl}_{2} \cdot \mathrm{DCM}$ (190 mg, $0.23 \mathrm{mmol}, 0.1$ equiv.), $\mathrm{Na}_{2} \mathrm{CO}_{3}$ (738 mg, $6.96 \mathrm{mmol}, 3.0$ equiv.), dioxane $(10 \mathrm{~mL})$ and water $(10 \mathrm{~mL})$ and the reaction was heated for $6 \mathrm{~h}$. The crude product was purified using flash column chromatography (gradient: $20-30 \%$ EtOAc-petrol) to give the titled compound ( $237 \mathrm{mg}, 0.74 \mathrm{mmol}, 32 \%)$ as an off-white powder. ${ }^{1} \mathbf{H}$ NMR (501 MHz, DMSO-d ): 13.47 (s, 1H), 7.75 (t, $J=1.1 \mathrm{~Hz}, 1 \mathrm{H}), 7.65$ (dd, $J=12.9,2.3 \mathrm{~Hz}, 1 \mathrm{H}$ ), $7.62(\mathrm{~d}, J=8.5 \mathrm{~Hz}, 1 \mathrm{H}), 7.55(\mathrm{ddd}, J=8.6,2.4,1.1 \mathrm{~Hz}, 1 \mathrm{H}), 7.52(\mathrm{dd}, J=8.5,1.5 \mathrm{~Hz}, 1 \mathrm{H}), 7.28(\mathrm{t}, J=$ $8.8 \mathrm{~Hz}, 1 \mathrm{H}), 3.90$ (s, 3H). ${ }^{13} \mathbf{C}$ NMR (126 MHz, DMSO-d $)$ ): 151.7 (d, $\left.J=243.9 \mathrm{~Hz}\right), 146.9$ (d, $J=10.8$ Hz), 141.6, 138.3, 132.9 (d, $J=6.6 \mathrm{~Hz}), 123.4$ (d, $J=3.2 \mathrm{~Hz}), 121.0,120.2,119.6,114.7,114.6,114.3$ $(\mathrm{d}, J=2.3 \mathrm{~Hz}), 107.9,56.1$. LC-MS (ES): $\mathrm{RT}=0.6-0.7 \mathrm{~min}, \mathrm{~m} / \mathrm{z}=321.24\left(\mathrm{M}+\mathrm{H}^{+}\right)$.

4-[6-(2-fluoro-4-methoxyphenyl)-1H-indazol-3-yl]aniline (S19)

Synthesised by method A using $\mathbf{S 1 7}(170 \mathrm{mg}, 0.53 \mathrm{mmol}, 1.0$ equiv.), 4-aminophenylboronic acid pinacol ester (232 mg, $1.06 \mathrm{mmol}, 2.0$ equiv.), $\mathrm{Pd}(\mathrm{dppf}) \mathrm{Cl}_{2} \bullet \mathrm{DCM}$ (43 mg, $0.053 \mathrm{mmol}, 0.1$ equiv.), $\mathrm{Na}_{2} \mathrm{CO}_{3}(168 \mathrm{mg}, 1.59 \mathrm{mmol}, 3.0$ equiv.), dioxane $(2.5 \mathrm{~mL})$ and water $(2.5 \mathrm{~mL})$ and the reaction was heated for $3 \mathrm{~h}$. The crude product was purified using flash column chromatography (isocratic: $2 \% 7.0$ $\mathrm{M} \mathrm{NH}_{3}$ in $\left.\mathrm{MeOH}-\mathrm{DCM}\right)$ to give the titled compound (115 mg, $\left.0.36 \mathrm{mmol}, 69 \%\right)$ as a yellow powder. ${ }^{1}$ H NMR (501 MHz, DMSO-d ${ }_{6}$ ): 12.92 (br.s, 1H), 8.04 (d, $\left.J=8.5 \mathrm{~Hz}, 1 \mathrm{H}\right), 7.71-7.62$ (m, 2H), 7.59 (s, 1H), $7.54(\mathrm{t}, J=9.0 \mathrm{~Hz}, 1 \mathrm{H}), 7.27(\mathrm{dt}, J=8.5,1.6 \mathrm{~Hz}, 1 \mathrm{H}), 6.97(\mathrm{dd}, J=12.9,2.5 \mathrm{~Hz}, 1 \mathrm{H}), 6.92(\mathrm{dd}$, $J=8.6,2.6 \mathrm{~Hz}, 1 \mathrm{H}), 6.74-6.67$ (m, 2H), 5.27 (s, 2H), 3.83 (br.s, 3H). ${ }^{13} \mathbf{C}$ NMR (126 MHz, DMSOd $)_{6}: 160.1(\mathrm{~d}, J=11.1 \mathrm{~Hz}), 159.8(\mathrm{~d}, J=245.5 \mathrm{~Hz}), 148.5,144.1,141.8,132.6,131.4(\mathrm{~d}, J=5.2 \mathrm{~Hz})$, 127.6, 121.5, 121.3, 121.0, 120.6 (d, $J=13.7 \mathrm{~Hz}), 118.9,114.0,110.9$ (d, $J=2.8 \mathrm{~Hz}), 109.8$ (d, $J=3.4$ $\mathrm{Hz}), 102.1(\mathrm{~d}, J=26.5 \mathrm{~Hz}), 55.7 . \mathbf{L C}-\mathbf{M S}(\mathbf{E S I}+)$ : $\mathrm{RT}=0.5-0.6 \mathrm{~min}, \mathrm{~m} / \mathrm{z}=334.36\left(\mathrm{M}+\mathrm{H}^{+}\right)$. 
4-[6-(3-fluoro-4-methoxyphenyl)-1H-indazol-3-yl]aniline (S20)

Synthesised by method A using $\mathbf{S 1 8}$ (214 mg, $0.67 \mathrm{mmol}, 1.0$ equiv.), 4-aminophenylboronic acid pinacol ester (292 mg, $1.33 \mathrm{mmol}, 2.0$ equiv.), $\mathrm{Pd}(\mathrm{dppf}) \mathrm{Cl}_{2} \bullet \mathrm{DCM}$ (54 mg, $0.067 \mathrm{mmol}, 0.1$ equiv.), $\mathrm{Na}_{2} \mathrm{CO}_{3}$ (212 mg, $2.00 \mathrm{mmol}, 3.0$ equiv.), dioxane $(2.5 \mathrm{~mL})$ and water $(2.5 \mathrm{~mL})$ and the reaction was heated for $3 \mathrm{~h}$. The crude oil was purified using flash column chromatography (isocratic: $2 \% \mathrm{MeOH}-$ DCM) and the resulting brown solid further purified using RP ACC (gradient: 20-49\% $\mathrm{MeCN}-\mathrm{H}_{2} \mathrm{O}-0.1 \%$ formic acid). Appropriate fractions were combined and concentrated in vacuo to a volume of $\sim 3 \mathrm{~mL}$ until a white precipitate had formed which was then filtered to give the titled compound (108 mg, $0.32 \mathrm{mmol}, 49 \%$ ) as an off-white powder. ${ }^{1} \mathbf{H}$ NMR (501 MHz, DMSO-d $)$ ): 12.93 (br.s, $1 \mathrm{H}), 8.02(\mathrm{~d}, J=8.5 \mathrm{~Hz}, 1 \mathrm{H}), 7.68(\mathrm{~d}, J=8.5 \mathrm{~Hz}, 3 \mathrm{H}), 7.63(\mathrm{dd}, J=12.9,2.3 \mathrm{~Hz}, 1 \mathrm{H}), 7.54$ (ddd, $J=8.6,2.4,1.1 \mathrm{~Hz}, 1 \mathrm{H}), 7.42(\mathrm{dd}, J=8.5,1.6 \mathrm{~Hz}, 1 \mathrm{H}), 7.27(\mathrm{t}, J=8.8 \mathrm{~Hz}, 1 \mathrm{H}), 6.74-6.67(\mathrm{~m}, 2 \mathrm{H})$, 5.27 (br.s, 2H), 3.90 (s, 3H). ${ }^{13}$ C NMR (126 MHz, DMSO-d $)$ ): 151.8 (d, $J=243.5$ Hz), 148.5, 146.6 (d, $J=10.5 \mathrm{~Hz}), 144.0,142.2,136.5,133.5$ (d, $J=6.5 \mathrm{~Hz}), 123.1$ (d, $J=3.2 \mathrm{~Hz}), 121.4,121.3,119.7$, 119.1, 114.5, 114.4, $114.3(\mathrm{~d}, J=2.2 \mathrm{~Hz}), 114.0,107.4,56.1$. LC-MS (ESI+): RT = 0.6-0.6 min, $\mathrm{m} / \mathrm{z}=334.38\left(\mathrm{M}+\mathrm{H}^{+}\right)$.

6-(2-fluoro-4-methoxyphenyl)-3-[4-(piperazin-1-yl)phenyl]-1 $H$-indazole (S21)

Synthesised by method G using S19 (106 mg, 0.34 mmol, 1.0 equiv.), 36 (73 mg, 0.40 mmol, 1.2 equiv.) and $\mathrm{K}_{2} \mathrm{CO}_{3}\left(112 \mathrm{mg}, 0.81 \mathrm{mmol}, 2.4\right.$ equiv.) and ${ }^{\mathrm{t}} \mathrm{BuOH}(5 \mathrm{~mL})$ and the reaction was heated for $159 \mathrm{~h}$. The reaction mixture was concentrated in vacuo and the resulting solid was purified by flash column chromatography (isocratic: 4\% 7.0 $\mathrm{M} \mathrm{NH}_{3}$ in $\mathrm{MeOH}-\mathrm{DCM}$ ) to give the titled compound (16 mg, 0.04 mmol, $12 \%$ ) as a brown solid. Due to time constraints, all available material was carried through immediately without full characterization. LC-MS (ES): $\mathrm{RT}=1.4-1.5 \mathrm{~min}, \mathrm{~m} / \mathrm{z}=334.18\left(\mathrm{M}+\mathrm{H}^{+}\right)$.

4-\{4-[6-(3-fluoro-4-methoxyphenyl)-1 $H$-indazol-3-yl]phenyl $\}$ piperazin-1-ium formate (S22)

Synthesised by method G using $\mathbf{S 2 0}$ (98 mg, 0.29 mmol, 1.0 equiv.), $\mathbf{3 6}$ (63 mg, $0.35 \mathrm{mmol}, 1.2$ equiv.), $\mathrm{K}_{2} \mathrm{CO}_{3}\left(98 \mathrm{mg}, 0.71 \mathrm{mmol}, 2.4\right.$ equiv.) and ${ }^{\mathrm{t}} \mathrm{BuOH}(5 \mathrm{~mL})$ and the reaction was heated for $152 \mathrm{~h}$. The reaction mixture was concentrated in vacuo to reveal a yellow solid which was dissolved in DMSO, and the solution was decanted from the insoluble impurities. The crude product was purified by RP ACC (gradient: $5-50 \% \mathrm{MeCN}-\mathrm{H}_{2} \mathrm{O}$ in $0.1 \%$ formic acid) and the resulting orange solid was triturated with $\mathrm{MeOH}$ to give the titled compound $(17 \mathrm{mg}, 0.042 \mathrm{mmol}, 14 \%$ ) as a pink solid. The filtrate from the trituration was reduced in vacuo the orange solid $(59 \mathrm{mg})$ used without further purification. ${ }^{1} \mathbf{H}$

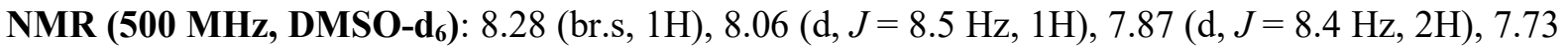
(br.s, 1H), 7.65 (dd, $J=12.9,2.2 \mathrm{~Hz}, 1 \mathrm{H}), 7.56$ (d, $J=8.5 \mathrm{~Hz}, 1 \mathrm{H}), 7.49-7.43$ (m, 1H), 7.28 (t, $J=8.8$ Hz, 1H), 7.09 (d, $J=8.4$ Hz, 2H), 3.90 (s, 3H), 3.24 (br.s, 5H), 3.01 (br.s, 4H). ${ }^{13}$ C NMR (101 MHz, DMSOd $\left._{6}\right): 164.3,151.8(\mathrm{~d}, J=243.5 \mathrm{~Hz}), 150.5,146.8,146.6,143.2,142.3,136.7,133.4,124.4,123.2$ (d, $J=3.2 \mathrm{~Hz}), 121.2,120.1,119.2,115.6,114.5$ (d, $J=18.8 \mathrm{~Hz}), 114.3,107.6,56.1,47.7,44.3$. LCMS (ESI+): RT $=0.5-0.6 \mathrm{~min}, \mathrm{~m} / \mathrm{z}=403.47\left(\mathrm{M}+\mathrm{H}^{+}\right)$. 
3-[4-(4-ethylpiperazin-1-yl)phenyl]-6-(4-methoxyphenyl)-1 $H$-indazole (S23)

Synthesised using method D using 37 (100 mg, $0.26 \mathrm{mmol}, 1.0$ equiv.), ethanal ( $18 \mu \mathrm{L}, 0.31 \mathrm{mmol}, 1.2$ equiv.), AcOH (1 drop), STAB ( $88 \mathrm{mg}, 0.42 \mathrm{mmol}, 1.6$ equiv.) and DCM (3 mL) and the reaction was stirred for $1 \mathrm{~h}$. The reaction mixture was reduced in vacuo and the crude product was purified flash column chromatography (isocratic: $3 \% 7.0 \mathrm{M} \mathrm{NH}_{3}$ in $\mathrm{MeOH}-\mathrm{DCM}$ ) to give the titled (90 $\mathrm{mg}, 0.22$ mmol, 84\%) as a colourless semi-solid. ${ }^{1} \mathbf{H}$ NMR (501 $\mathbf{~ M H z , ~} \mathbf{C D C l}_{3}$ ): 11.88 (s, 1H), 8.01 (d, $J=8.9$ $\mathrm{Hz}, 1 \mathrm{H}), 7.98-7.91$ (m, 2H), 7.54-7.47 (m, 2H), 7.41-7.35 (m, 2H), 7.09-7.03 (m, 2H), 7.02-6.94 (m, 2H), $5.29(\mathrm{~s}, 1 \mathrm{H}), 3.84(\mathrm{~s}, 3 \mathrm{H}), 3.27(\mathrm{t}, J=5.1 \mathrm{~Hz}, 4 \mathrm{H}), 2.63(\mathrm{~d}, J=5.1 \mathrm{~Hz}, 4 \mathrm{H}), 2.50(\mathrm{q}, J=7.2 \mathrm{~Hz}$, 2H), 1.15 (t, $J=7.2 \mathrm{~Hz}, 3 \mathrm{H}) .{ }^{13} \mathbf{C}$ NMR (101 MHz, $\left.\mathbf{C D C l}_{3}\right)$ : 159.4, 151.3, 145.6, 142.7, 139.7, 133.9, 128.7, 128.6, 124.8, 121.5, 121.1, 119.9, 116.1, 114.4, 107.8, 55.5, 52.9, 52.5, 48.8, 12.1. LC-MS (ESI+): RT $=0.6-0.7 \mathrm{~min}, \mathrm{~m} / \mathrm{z}=413.49\left(\mathrm{M}+\mathrm{H}^{+}\right)$.

\section{Biology}

\section{FRET-based assay}

Biochemical data was obtained via the Z'-LYTE ${ }^{\mathrm{TM}}$ kinase screening service (ThermoFisher) ${ }^{51}$ Additional details can be found in the Supporting Information.

\section{Expression and Purification of FGFR2}

A dual plasmid containing WT FGFR2 (residues 461-763) and protein tyrosine phosphatase-1B (PTP-1B) (Addgene \#8602) was transformed into competent BL21 (DE3) cells and the cells used to inoculate kanamycin- $(50 \mu \mathrm{g} / \mathrm{mL})$ and ampicillin- $(50 \mu \mathrm{g} / \mathrm{mL})$ treated Lysogeny broth (LB) agar plates. Single colonies used to inoculate $100 \mathrm{~mL} \mathrm{LB}$ and the media grown overnight at $37^{\circ} \mathrm{C}, 200 \mathrm{rpm}$. This culture was used to inoculate $1 \mathrm{~L}$ of $\mathrm{LB}$ and the $\mathrm{LB}$ grown at $37^{\circ} \mathrm{C}, 200 \mathrm{rpm}$ until $\mathrm{OD}_{600} \sim 0.7$ and the cultures induced using isopropyl $\beta$-d-1-thiogalactopyranoside (IPTG, $0.1 \mathrm{mM}$ ) and incubated at $16{ }^{\circ} \mathrm{C}$ overnight. Cultures were harvested and cell pellets were suspended in $5 \mathrm{~mL}$ of lysis buffer ( $20 \mathrm{mM}$ Tris, pH 8.0, $300 \mathrm{mM} \mathrm{NaCl}, 10 \mathrm{mM}$ imidazole, $2 \mathrm{mM}$ tris(2-carboxyethyl)phosphone (TCEP)) and one protease tablet (cOmplete ${ }^{\mathrm{TM}}$, EDTA-free Protease Inhibitor Cocktail-Sigma) and $5 \mu \mathrm{L}$ of benzonase ${ }^{\circledR}$ $(\geq 250 \mathrm{U} / \mu \mathrm{L}$-Sigma) were added and the cell mixture lysed via sonication. Lysates were centrifuged at $4{ }^{\circ} \mathrm{C}, 20,000 \mathrm{rpm}$ for $1 \mathrm{~h}$ and the supernatant loaded onto $5 \mathrm{~mL}$ cobalt TALON ${ }^{\circledR}$ resin (Clontech) and the resin was washed and step-eluted with lysis buffer containing $250 \mathrm{mM}$ imidazole. Fractions were analysed by SDS-PAGE and dialysed into $20 \mathrm{mM}$ 4-(2-hydroxyethyl)-1-piperazineethanesulfonic acid (HEPES), $\mathrm{pH}$ 8.0, $100 \mathrm{mM} \mathrm{NaCl} 1 \mathrm{mM}$ TCEP and the His 6 -tag removed by incubation with thrombin $(1 \mathrm{U} / \mu \mathrm{L})$ overnight. The mixture was then added to cobalt/benzamidine resin and mixed for 15 minutes to remove the His tag. Supernatant was further purified in a Superdex 100 column using buffer containing $20 \mathrm{mM}$ HEPES, pH 7.5, $100 \mathrm{mM} \mathrm{NaCl}, 1 \mathrm{mM}$ TCEP. Purified FGFR2 protein was concentrated to $\sim 10 \mathrm{mg} / \mathrm{mL}$ for direct use in crystal trials. 


\section{Expression and Purification of FGFR1}

BL21 star (DE3) cells containing the FGFR1 kinase construct (residues 458-765, C488A, C548S) was kindly provided by Professor Alexander Breeze and used to inoculate 1L of tetracycline$(12.5 \mu \mathrm{g} / \mathrm{mL})$ and ampicillin- $(100 \mu \mathrm{g} / \mathrm{mL})$ treated Terrific broth (TB). Protein expression followed the same protocol as outlined for FGFR2. Purification of FGFR1 was done using a His-Trap ${ }^{\text {TM }}$ High Performance column (GE Healthcare) Ni-NTA column connected to an ÄKTA prime. Appropriate fractions were pooled and dialysed into ion exchange (IEX) buffer (20 mM Tris, pH 8.0, $1 \mathrm{mM}$ TCEP) containing tobacco etch virus (TEV) protease ( $\geq 3000 \mathrm{U} / \mathrm{mg}$-Sigma) overnight to cleave the His tag. Protein was loaded onto a $5 \mathrm{~mL}$ Q Sepharose column (GE Healthcare), washed with IEX buffer, and the protein was eluted with IEX buffer containing $1 \mathrm{M} \mathrm{NaCl}$. IEX-purified fractions were directly loaded onto a Superdex 75 column and protein was eluted in buffer containing $20 \mathrm{mM}$ Tris, $\mathrm{pH}$ 7.8, 20 $\mathrm{mM} \mathrm{NaCl}, 2 \mathrm{mM}$ TCEP. Protein was concentrated to $\sim 10 \mathrm{mg} / \mathrm{mL}$ for direct use in crystal trials.

\section{Co-crystallisation and Data Collection}

FGFR2, at a concentration of $0.29 \mathrm{mM}(10 \mathrm{mg} / \mathrm{mL})$ in $20 \mathrm{mM}$ HEPES, pH 7.5, $100 \mathrm{mM} \mathrm{NaCl}$, $1 \mathrm{mM}$ TCEP, was mixed with 38 ([ ] $\left.]_{\mathrm{f}} 0.29 \mathrm{mM}, 5 \% \mathrm{DMSO}\right)$. Protein/ligand solutions $(0.2 \mu \mathrm{L})$ were then mixed with $0.2 \mu \mathrm{L}$ of $25 \%$ PEG 3350, $100 \mathrm{mM}\left(\mathrm{NH}_{4}\right)_{2} \mathrm{SO}_{4}, 100 \mathrm{mM}$ HEPES, $\mathrm{pH}$ 7.6. Crystals were then grown at $20^{\circ} \mathrm{C}$ using the vapour diffusion method and crystals appeared between $2-4$ weeks. The crystals were flash-cooled in liquid nitrogen after soaking for 30 seconds in mother liquor solution containing $25 \%(\mathrm{v} / \mathrm{v})$ ethylene glycol as a cryo-protectant. X-ray diffraction data was collected at the European Synchrotron Radiation Facility (ESRF) on beamline ID30A-1 at $100 \mathrm{~K}$. The diffraction images were indexed and integrated using DIALS ${ }^{67}$ before subsequent scaling in AIMLESS $^{68}$ and data processing in the $\mathrm{CCP} 4 \mathrm{i} 2$ suite. ${ }^{69}$ The unit cell parameters for the crystal are $\mathrm{a}=\mathrm{b}=113.8 \AA$, $\mathrm{c}=117.4 \AA$, $\alpha=\beta=\gamma=90.0^{\circ}$ in space group $P 4_{1} 2_{1} 2$ with two FGFR2 molecules in the asymmetric unit cell. The structure was determined by molecular replacement using the program PHASER ${ }^{70}$ with the human FGFR2 structure (PDB 2PVF) as the search model. ${ }^{71}$ Iterative cycles of manual model building using both $2 F_{\mathrm{o}}-F_{\mathrm{c}}$ and $F_{\mathrm{o}}-F_{\mathrm{c}}$ maps and refinement were carried out using $\mathrm{COOT}^{72}$ and REFMAC5 ${ }^{73}$, respectively. The coordinate and the restraint dictionary files for the compound were generated using JLigand. ${ }^{74}$ Ligands, sulphates, chloride ions, ethylene glycols, and waters were manually added into the density using COOT. Structural validations were carried out using MOLPROBITY. ${ }^{75}$

FGFR1, at a concentration of $0.28 \mathrm{mM}(10 \mathrm{mg} / \mathrm{mL})$ in $20 \mathrm{mM}$ Tris, $\mathrm{pH} 7.8,20 \mathrm{mM} \mathrm{NaCl}, 2$ $\mathrm{mM}$ TCEP, was mixed with 19, 34 and $\mathbf{3 8}$ ([ ] $0.28 \mathrm{mM}, 0.5 \%$ DMSO) and then crystals grown as outlined for FGFR2 using 0.185 M ammonium sulphate, 20\% ethylene glycol, 16-22\% PEG 8000, pH (6.2-6.8) as the screening conditions. Crystals were grown at $4{ }^{\circ} \mathrm{C}$ using the vapour diffusion method and crystals appeared between 1-2 weeks. Crystals were flash-cooled in liquid nitrogen and the data was collected at the Diamond Light Source (DLS) on beamline I04-1 on $100 \mathrm{~K}$. Data reduction, 
structure determination, model building, and refinement were conducted in the same manner as FGFR2. The unit cell parameters for the FGFR1 crystals are $a=207.8 \AA, b=57.5 \AA, c=66.0 \AA, \beta=107.4^{\circ}$ in space group $C 2$ with two FGFR1 molecules in the asymmetric unit cell. The structures were determined by molecular replacement with the human FGFR1 structure (PDB 5A46) as the search model. ${ }^{76}$

\section{CellTiter-Blue ${ }^{\circledR}$ Viability Assay}

Human cell lines used in this work were: JMSU1, SUM52, VMCUB3. JMSU1 was obtained in 2003 from German Collection of Microorganisms and Cell Cultures (DSMZ) and authenticated in 2012 by short tandem repeats (STR) profiling. SUM52 was obtained from the Professor Nick Turner, Institute for Cancer Research, London, in 2017. VMCUB3 was obtained in 2001 from the Institute of Cancer Studies, Leeds, and was authenticated in 2012 by STR profiling. Cells were regularly tested for mycoplasma by PCR and cultured for a maximum of 10 passages from the authenticated stock.

JMSU1 and SUM52 cells were routinely cultured in Roswell Park Memorial Institute (RPMI)1640 growth medium (Sigma) and VMCUB3 cells were cultured in Dulbecco's modified Eagle medium (DMEM) (Sigma), all containing 10\% foetal calf serum (FCS, Biosera) and 2 mM GlutaMAX (Life Technologies), in a humidified incubator at $37{ }^{\circ} \mathrm{C}$ in an atmosphere of $5 \% \mathrm{CO}_{2}$. Cells were seeded at a density of $5 \times 10^{3}$ cells/well into a flat bottom 96-well plate (Corning) and incubated at $37{ }^{\circ} \mathrm{C}$ for $24 \mathrm{~h}$. Medium was replaced with solutions of 38, 41, 42 and PD173074 in medium (Sigma) at varying concentrations $\left(0.1 \%\right.$ [ ] $\mathrm{f}$ DMSO) and plates incubated at $37{ }^{\circ} \mathrm{C}, 5 \% \mathrm{CO}_{2}$ for $72 \mathrm{~h}$. Five wells were assayed per condition. Pre-warmed CellTiter Blue reagent (Promega, $20 \mu \mathrm{L}$ per well) was added and plates incubated at $37{ }^{\circ} \mathrm{C}, 5 \% \mathrm{CO}_{2}$ for $2 \mathrm{~h}$ in the dark. After incubation, $50 \mu \mathrm{L}$ of $3 \%$ SDS was added to each well and the fluorescence immediately read (ex/em 540/590 nm) on a Berthold Mithras LB 940 Multimode plate reader. Wells were blanked with a medium-only control and then normalised to the DMSO vehicle control. Assays were repeated at least once using independent drug dilution series. Data were plotted using Origin ${ }^{\circledR} 2016$ and $\mathrm{IC}_{50}$ values calculated using a dose-response non-linear curve fit.

\section{Computational Modelling}

All docking studies were carried out using Maestro (version 11.1) by Schrödinger Inc using the OPLS3 force field for parameterization. ${ }^{77}$ The X-ray crystal structure of FGFR1 (PDB 5B7V) ${ }^{49}$ was imported from the PDB and prepared using the protein preparation function using default settings. Ligands were drawn and prepared using the LigPrep function. A Glide docking grid was generated by using the co-crystallised ligand as a template and docking performed using extra precision. Output files were visualised in PyMol (version 2.0, Schrödinger, LLC) and used for figures throughout this manuscript. 


\section{Interference Compound Filter}

All final compounds were examined for pan-assay interference potential using the ZINC patterns search (http://zinc15.docking.org/patterns/home) and no compounds were flagged.

\section{Associated Content}

\section{Supporting Information}

The Supporting Information is available free of charge at:

Supporting schemes, figures, and tables. Additional information: SPROUT modules, Z'-LYTE assay, CellTiter-Blue viability assay. Appendix One: FGFR1 analysis, FGFR2 analysis, FGFR1 crystal. Appendix Two: Z'-LYTE IC 50 curves, CellTiter-Blue IC $_{50}$ curves, HPLC chromatograms, NMR spectra.

\section{PDB ID codes}

X-ray diffraction data, coordinates, and structure factors for the X-ray crystal structures are deposited on the PDB under accession codes 7OZF (FGFR1/19), 7OZD (FGFR1/34), 7OZB (FGFR1/38), and 7OZY (FGFR2/38). Authors will release the atomic coordinates and experimental data upon article publication.

\section{Author Information}

\section{Corresponding Author}

Colin W. G. Fishwick - School of Chemistry, University of Leeds, Leeds, LS2 9JT, U.K. ORCID ID: 0000-0003-1283-2181. Email: c.w.g.fishwick@leeds.ac.uk

\section{Authors}

Lewis D. Turner - School of Chemistry, University of Leeds, Leeds, LS2 9JT, U.K. Current address: Department of Chemistry, Scripps Research, 10550 N Torrey Pines Road, La Jolla, CA 92037, US. ORCID ID: 0000-0003-0660-8247.

Chi H. Trinh - Astbury Centre for Structural Molecular Biology, Institute of Molecular and Cellular Biology, University of Leeds, Leeds, LS2 9JT, UK. ORCID ID: 0000-0002-5087-5011.

Ryan A. Hubball - School of Chemistry, University of Leeds, Leeds, LS2 9JT, U.K. ORCID ID: 0000-0001-6006-6114.

Kyle M. Orritt - School of Chemistry, University of Leeds, Leeds, LS2 9JT, U.K. ORCID ID: 0000-0001-5878-7609.

Chi-Chuan Lin - Astbury Centre for Structural Molecular Biology, Institute of Molecular and Cellular Biology, University of Leeds, Leeds, LS2 9JT, UK. ORCID ID: 0000-0003-3071-172X.

Julie E. Burns - Leeds Institute of Medical Research at St James's, University of Leeds, LS9 7TF, UK. ORCID ID: 0000-0003-1238-8826. 
Margaret A. Knowles - Leeds Institute of Medical Research at St James's, University of Leeds, LS9 7TF, UK. ORCID ID: 0000-0002-9363-8657.

\title{
Author Contributions
}

L.D.T conceptualized the study and performed: chemical synthesis, computational methods, protein expression, purification, crystallography, and cell viability assays; C.H.T supervised FGFR1 expression and crystallography, and performed data refinement; C.L supervised FGFR2 expression; J.E.B supervised cell viability assays; L.D.T wrote the original draft of the manuscript with input from C.H.T, R.A.H and K.M.O and all authors revised the final version; M.A.K and C.W.G.F acquired funding and supervised the study.

\section{Notes}

The authors declare no competing financial interest.

\section{Acknowledgements}

The authors thank Abbey Summers and Laura Johnson for synthesis of intermediates, members of the Astbury centre including Professors Richard Bayliss, Alexander Breeze, and John Ladbury for their pivotal role in coordinating the biochemical aspects of this work, and Life Technologies Ltd for conducting the Z'-LYTE assay. This work was supported by the Medical Research Council grant $\mathrm{MR} / \mathrm{K} 501402 / 1$.

\begin{abstract}
Abbreviations
ACC, automated column chromatography; DFG, Asp-Phe-Gly; DLSF, Diamond Light Source Facility; DMEM, Dulbecco's modified Eagle medium; DSMZ, Germain Collection of Microorganisms and Cell Cultures; ESRF, European Synchrotron Radiation Facility; foetal calf serum; FGFR, fibroblast growth factor receptor; HEPES, 4-(2-hydroxyethyl)-1-piperazineethanesulfonic acid; HER2, human epidermal growth factor 2; IEX, ion exchance; isopropyl ß-d-1-thiogalactopyranoside; LB, Lysogeny broth; ND, not determined; NP, normal phase; PLC $\gamma$, phospholipase C gamma; RP, reverse phase; RPMI, Roswell Park Memorial Institute; SD, standard deviation; STAB, sodium triacetoxyborohydride; STAT, signal transducer and activator of transcription proteins; STR, short tandem repeats; TCEP, tris(2-carboxyethyl)phosphone; TEV, tobacco etch virus.
\end{abstract}

\section{References}

1. Groth, C.; Lardelli, M. The structure and function of vertebrate Fibroblast Growth Factor Receptor 1. Int. J. Dev. Biol. 2002, 46, 393-400. 
2. Eswarakumar, V. P.; Lax, I.; Schlessinger, J. Cellular signaling by fibroblast growth factor receptors. Cytokine. Growth. F. R. 2005, 16, 139-149.

3. Presta, M.; Dell'Era, P.; Mitola, S.; Moroni, E.; Ronca, R.; Rusnati, M. Fibroblast growth factor/fibroblast growth factor receptor system in angiogenesis. Cytokine. Growth. F. R. 2005, 16, 159178.

4. Cross, M. J.; Claesson-Welsh, L. FGF and VEGF function in angiogenesis: signalling pathways, biological responses and therapeutic inhibition. Trends Pharmacol. Sci. 2001, 22, 201-207.

5. Furdui, C. M.; Lew, E. D.; Schlessinger, J.; Anderson, K. S. Autophosphorylation of FGFR1 kinase is mediated by a sequential and precisely ordered reaction. Mol. Cell. 2006, 21, 711-717.

6. Lew, E. D.; Furdui, C. M.; Anderson, K. S.; Schlessinger, J. The Precise Sequence of FGF Receptor Autophosphorylation Is Kinetically Driven and Is Disrupted by Oncogenic Mutations. Sci. Signal. 2009, 2, ra6.

7. Ornitz, D. M.; Itoh, N. The Fibroblast Growth Factor signaling pathway. Wires. Dev Biol. 2015, 4, 215-266.

8. Di Martino, E.; Tomlinson, D. C.; Knowles, M. A. A Decade of FGF Receptor Research in Bladder Cancer: Past, Present, and Future Challenges. Adv. Urol. 2012, 2012, 429214.

9. Byron, S. A.; Chen, H.; Wortmann, A.; Loch, D.; Gartside, M. G.; Dehkhoda, F.; Blais, S. P.; Neubert, T. A.; Mohammadi, M.; Pollock, P. M. The N550K/H mutations in FGFR2 confer differential resistance to PD173074, dovitinib, and ponatinib ATP-competitive inhibitors. Neoplasia. 2013, 15, 975-988.

10. Kim, S.; Dubrovska, A.; Salamone, R. J.; Walker, J. R.; Grandinetti, K. B.; Bonamy, G. M. C.; Orth, A. P.; Elliott, J.; Porta, D. G.; Garcia-Echeverria, C.; Reddy, V. A. FGFR2 promotes breast tumorigenicity through maintenance of breast tumor-initiating cells. PloS one. 2013, 8, e51671-e51671. 11. Weiss, J.; Sos, M. L.; Seidel, D.; Peifer, M.; Zander, T.; Heuckmann, J. M.; Ullrich, R. T.; Menon, R.; Maier, S.; Soltermann, A.; Moch, H.; Wagener, P.; Fischer, F.; Heynck, S.; Koker, M.; Schöttle, J.; Leenders, F.; Gabler, F.; Dabow, I.; Querings, S.; Heukamp, L. C.; Balke-Want, H.; Ansén, S.; Rauh, D.; Baessmann, I.; Altmüller, J.; Wainer, Z.; Conron, M.; Wright, G.; Russell, P.; Solomon, B.; Brambilla, E.; Brambilla, C.; Lorimier, P.; Sollberg, S.; Brustugun, O. T.; Engel-Riedel, W.; Ludwig, C.; Petersen, I.; Sänger, J.; Clement, J.; Groen, H.; Timens, W.; Sietsma, H.; Thunnissen, E.; Smit, E.; Heideman, D.; Cappuzzo, F.; Ligorio, C.; Damiani, S.; Hallek, M.; Beroukhim, R.; Pao, W.; Klebl, B.; Baumann, M.; Buettner, R.; Ernestus, K.; Stoelben, E.; Wolf, J.; Nürnberg, P.; Perner, S.; Thomas, R. K. Frequent and Focal FGFR1 Amplification Associates with Therapeutically Tractable FGFR1 Dependency in Squamous Cell Lung Cancer. Sci. Transl. Med. 2010, 2, 62 ra93.

12. Babina, I. S.; Turner, N. C. Advances and challenges in targeting FGFR signalling in cancer. Nat. Rev. Cancer 2017, 17, 318-332.

13. Liu, F.-T.; Li, N.-G.; Zhang, Y.-M.; Xie, W.-C.; Yang, S.-P.; Lu, T.; Shi, Z.-H. Recent advance in the development of novel, selective and potent FGFR inhibitors. Eur. J. Med. Chem. 2020, 186, 111884 .

14. Facchinetti, F.; Hollebecque, A.; Bahleda, R.; Loriot, Y.; Olaussen, K. A.; Massard, C.; Friboulet, L. Facts and New Hopes on Selective FGFR Inhibitors in Solid Tumors. Clin. Cancer Res. 2020, 26, 764-774.

15. Luo, H.; Zhang, T.; Cheng, P.; Li, D.; Ogorodniitchouk, O.; Lahmamssi, C.; Wang, G.; Lan, M. Therapeutic implications of fibroblast growth factor receptor inhibitors in a combination regimen for solid tumors. Oncol. Lett. 2020, 20, 2525-2536.

16. Weaver, A.; Bossaer, J. B. Fibroblast growth factor receptor (FGFR) inhibitors: A review of a novel therapeutic class. J. Oncol. Pharm. Pract. 2021, 27, 702-710.

17. Yue, S.; Li, Y.; Chen, X.; Wang, J.; Li, M.; Chen, Y.; Wu, D. FGFR-TKI resistance in cancer: current status and perspectives. J. Hematol. Oncol. 2021, 14, 23.

18. Roskoski, R. Classification of small molecule protein kinase inhibitors based upon the structures of their drug-enzyme complexes. Pharmacol. Res. 2016, 103, 26-48.

19. Markham, A. Erdafitinib: First Global Approval. Drugs 2019, 79, 1017-1021.

20. Kufareva, I.; Abagyan, R. Type-II kinase inhibitor docking, screening, and profiling using modified structures of active kinase states. J. Med. Chem. 2008, 51, 7921-7932.

21. U.S. Food and Drug Administration. 2021 Notifications 

13/06/2021).

22. Tsimafeyeu, I.; Daeyaert, F.; Yin, W.; Ludes-Meyers, J.; Byakhov, M.; Tjulandin, S. 476 FGFR2 targeting with allosteric inhibitor RPT835. Eur. J. Cancer. 2014, 50 (Suppl. 6), 155.

23. Tyulyandina, A.; Harrison, D.; Yin, W.; Stepanova, E.; Kochenkov, D.; Solomko, E.; Peretolchina, N.; Daeyaert, F.; Joos, J.-B.; Van Aken, K.; Byakhov, M.; Gavrilova, E.; Tjulandin, S.; Tsimafeyeu, I. Alofanib, an allosteric FGFR2 inhibitor, has potent effects on ovarian cancer growth in preclinical studies. Invest. New. Drugs. 2017, 35, 127-133.

24. U.S. National Libray of Medicine. Study of Alofanib in Patients With Metastatic Gastric cancer. https://clinicaltrials.gov/ct2/show/NCT04071184 (accessed 12/06/2021).

25. Hah, J. M.; Sharma, V.; Li, H.; Lawrence, D. S. Acquisition of a "Group A"-selective Src kinase inhibitor via a global targeting strategy. J. Am. Chem. Soc. 2006, 128, 5996-5997.

26. Hill, Z. B.; Perera, B. G.; Maly, D. J. A chemical genetic method for generating bivalent inhibitors of protein kinases. J. Am. Chem. Soc. 2009, 131, 6686-6688.

27. Vandana, L.; Indraneel, G. New Directions in Targeting Protein Kinases: Focusing Upon True Allosteric and Bivalent Inhibitors. Curr. Pharm. Des. 2012, 18, 2936-2945.

28. Zhou, W.; Hur, W.; McDermott, U.; Dutt, A.; Xian, W.; Ficarro, S. B.; Zhang, J.; Sharma, S. V.; Brugge, J.; Meyerson, M.; Settleman, J.; Gray, N. S. A structure-guided approach to creating covalent FGFR inhibitors. Chem. Biol. 2010, 17, 285-295.

29. Brameld, K. A.; Owens, T. D.; Verner, E.; Venetsanakos, E.; Bradshaw, J. M.; Phan, V. T.; Tam, D.; Leung, K.; Shu, J.; LaStant, J.; Loughhead, D. G.; Ton, T.; Karr, D. E.; Gerritsen, M. E.; Goldstein, D. M.; Funk, J. O. Discovery of the Irreversible Covalent FGFR Inhibitor 8-(3-(4Acryloylpiperazin-1-yl)propyl)-6-(2,6-dichloro-3,5-dimethoxyphenyl)-2-(methylamino)pyrido[2,3-

d] pyrimidin-7(8H)-one (PRN1371) for the Treatment of Solid Tumors. J. Med. Chem. 2017, 60, 65166527.

30. Fumarola, C.; Bozza, N.; Castelli, R.; Ferlenghi, F.; Marseglia, G.; Lodola, A.; Bonelli, M.; La Monica, S.; Cretella, D.; Alfieri, R.; Minari, R.; Galetti, M.; Tiseo, M.; Ardizzoni, A.; Mor, M.; Petronini, P. G. Expanding the Arsenal of FGFR Inhibitors: A Novel Chloroacetamide Derivative as a New Irreversible Agent With Anti-proliferative Activity Against FGFR1-Amplified Lung Cancer Cell Lines. Front. Oncol. 2019, 9, 179.

31. Fairhurst, R. A.; Knoepfel, T.; Buschmann, N.; Leblanc, C.; Mah, R.; Todorov, M.; Nimsgern, P.; Ripoche, S.; Niklaus, M.; Warin, N.; Luu, V. H.; Madoerin, M.; Wirth, J.; Graus-Porta, D.; Weiss, A.; Kiffe, M.; Wartmann, M.; Kinyamu-Akunda, J.; Sterker, D.; Stamm, C.; Adler, F.; Buhles, A.; Schadt, H.; Couttet, P.; Blank, J.; Galuba, I.; Trappe, J.; Voshol, J.; Ostermann, N.; Zou, C.; Berghausen, J.; Del Rio Espinola, A.; Jahnke, W.; Furet, P. Discovery of Roblitinib (FGF401) as a ReversibleCovalent Inhibitor of the Kinase Activity of Fibroblast Growth Factor Receptor 4. J. Med. Chem. 2020, 63, 12542-12573.

32. Liu, H.; Niu, D.; Tham Sjin, R. T.; Dubrovskiy, A.; Zhu, Z.; McDonald, J. J.; Fahnoe, K.; Wang, Z.; Munson, M.; Scholte, A.; Barrague, M.; Fitzgerald, M.; Liu, J.; Kothe, M.; Sun, F.; Murtie, J.; Ge, J.; Rocnik, J.; Harvey, D.; Ospina, B.; Perron, K.; Zheng, G.; Shehu, E.; D’Agostino, L. A. Discovery of Selective, Covalent FGFR4 Inhibitors with Antitumor Activity in Models of Hepatocellular Carcinoma. ACS Med. Chem. Lett. 2020, 11, 1899-1904.

33. Hagel, M.; Miduturu, C.; Sheets, M.; Rubin, N.; Weng, W. F.; Stransky, N.; Bifulco, N.; Kim, J. L.; Hodous, B.; Brooijmans, N.; Shutes, A.; Winter, C.; Lengauer, C.; Kohl, N. E.; Guzi, T. First Selective Small Molecule Inhibitor of FGFR4 for the Treatment of Hepatocellular Carcinomas with an Activated FGFR4 Signaling Pathway. Cancer. Discov. 2015, 5, 424-437.

34. Chae, Y. K.; Ranganath, K.; Hammerman, P. S.; Vaklavas, C.; Mohindra, N.; Kalyan, A.; Matsangou, M.; Costa, R.; Carneiro, B.; Villaflor, V. M.; Cristofanilli, M.; Giles, F. J. Inhibition of the fibroblast growth factor receptor (FGFR) pathway: the current landscape and barriers to clinical application. Oncotarget. 2017, 8, 16052-16074.

35. Krook, M. A.; Lenyo, A.; Wilberding, M.; Barker, H.; Dantuono, M.; Bailey, K. M.; Chen, H.Z.; Reeser, J. W.; Wing, M. R.; Miya, J.; Samorodnitsky, E.; Smith, A. M.; Dao, T.; Martin, D. M.; Ciombor, K. K.; Hays, J.; Freud, A. G.; Roychowdhury, S. Efficacy of FGFR Inhibitors and Combination Therapies for Acquired Resistance in FGFR2-Fusion Cholangiocarcinoma. Mol. Cancer Ther. 2020, 19, 847-857. 
36. Cleary, J. M.; Raghavan, S.; Wu, Q.; Li, Y. Y.; Spurr, L. F.; Gupta, H. V.; Rubinson, D. A.; Fetter, I. J.; Hornick, J. L.; Nowak, J. A.; Siravegna, G.; Goyal, L.; Shi, L.; Brais, L. K.; Loftus, M.; Shinagare, A. B.; Abrams, T. A.; Clancy, T. E.; Wang, J.; Patel, A. K.; Brichory, F.; Vaslin Chessex, A.; Sullivan, R. J.; Keller, R. B.; Denning, S.; Hill, E. R.; Shapiro, G. I.; Pokorska-Bocci, A.; Zanna, C.; Ng, K.; Schrag, D.; Janne, P. A.; Hahn, W. C.; Cherniack, A. D.; Corcoran, R. B.; Meyerson, M.; Daina, A.; Zoete, V.; Bardeesy, N.; Wolpin, B. M. FGFR2 Extracellular Domain In-Frame Deletions are Therapeutically Targetable Genomic Alterations that Function as Oncogenic Drivers in Cholangiocarcinoma. Cancer. Discov. 2021, in press.

37. American Cancer Society. Key Statistics for Bile Duct Cancer. https://www.cancer.org/cancer/bile-duct-cancer/about/key-statistics.html (accessed 14/06/2021).

38. Fernández-Nogueira, P.; Mancino, M.; Fuster, G.; López-Plana, A.; Jauregui, P.; Almendro, V.; Enreig, E.; Menéndez, S.; Rojo, F.; Noguera-Castells, A.; Bill, A.; Gaither, L. A.; Serrano, L.; Recalde-Percaz, L.; Moragas, N.; Alonso, R.; Ametller, E.; Rovira, A.; Lluch, A.; Albanell, J.; Gascon, P.; Bragado, P. Tumor-Associated Fibroblasts Promote HER2-Targeted Therapy Resistance through FGFR2 Activation. Clin. Cancer Res. 2020, 26, 1432-1448.

39. Casaletto, J.; Maglic, D.; Touré, B. B.; Taylor, A.; Schoenherr, H.; Hudson, B.; Bruderek, K.; Zhao, S.; O'Hearn, P.; Gerami-Moayed, N.; Moustakas, D.; Valverde, R.; Foster, L.; Gunaydin, H.; Ayaz, P.; Sharon, D.; Berstrom, D.; Watters, J. RLY-4008, a Novel Precision Therapy for FGFR2Driven Cancers Desgined to Potently and Selectively Inhibit FGFR2 and FGFR2 Resistance Mutations. In American Association of Cancer Research Annual Virtual Meeting, 2021.

40. United States Securities and Exchange Commission. Form S-1 Registration Statement Relay Therapeutics, Inc (Pg https://www.sec.gov/Archives/edgar/data/1812364/000119312520177746/d924757ds1.htm (accessed 12/06/2021).

41. U.S National Library of Medicine. First-in-Human Study of Highly Selective FGFR2 Inhibitor, RLY-4008, in Patients with ICC and Other Advanced Solid Tumors. https://www.clinicaltrials.gov/ct2/show/NCT04526106?term=RLY-4008\&draw=2\&rank=1 (accessed $14 / 06 / 2021)$.

42. Turner, L. D.; Summers, A. J.; Johnson, L. O.; Knowles, M. A.; Fishwick, C. W. G. Identification of an Indazole-Based Pharmacophore for the Inhibition of FGFR Kinases Using Fragment-Led de Novo Design. ACS Med. Chem. Lett. 2017, 8, 1264-1268.

43. Gillet, V.; Johnson, A. P.; Mata, P.; Sike, S.; Williams, P. SPROUT - A Program for Structure Generation. J. Comput. Aid. Mol. Des. 1993, 7, 127-153.

44. Gillet, V. J.; Newell, W.; Mata, P.; Myatt, G.; Sike, S.; Zsoldos, Z.; Johnson, A. P. SPROUT Recent Developments in the De-Novo Design of Molecules. J. Chem. Inf. Comput. Sci. 1994, 34, $207-$ 217.

45. Friesner, R. A.; Banks, J. L.; Murphy, R. B.; Halgren, T. A.; Klicic, J. J.; Mainz, D. T.; Repasky, M. P.; Knoll, E. H.; Shelley, M.; Perry, J. K.; Shaw, D. E.; Francis, P.; Shenkin, P. S. Glide: A new approach for rapid, accurate docking and scoring. 1. Method and assessment of docking accuracy. $J$. Med. Chem. 2004, 47, 1739-1749.

46. Roth, G. J.; Binder, R.; Colbatzky, F.; Dallinger, C.; Schlenker-Herceg, R.; Hilberg, F.; Wollin, S. L.; Kaiser, R. Nintedanib: From Discovery to the Clinic. J. Med. Chem. 2015, 58, 1053-1063.

47. Liu, J.; Peng, X.; Dai, Y.; Zhang, W.; Ren, S. M.; Ai, J.; Geng, M. Y.; Li, Y. X. Design, synthesis and biological evaluation of novel FGFR inhibitors bearing an indazole scaffold. Org. Biomol. Chem. 2015, 13, 7643-7654.

48. Zhao, B.; Li, Y.; Xu, P.; Dai, Y.; Luo, C.; Sun, Y.; Ai, J.; Geng, M.; Duan, W. Discovery of Substituted $1 H$-Pyrazolo[3,4-b]pyridine Derivatives as Potent and Selective FGFR Kinase Inhibitors. ACS Med. Chem. Lett. 2016, 7, 629-634.

49. Nakanishi, Y.; Akiyama, N.; Tsukaguchi, T.; Fujii, T.; Sakata, K.; Sase, H.; Isobe, T.; Morikami, K.; Shindoh, H.; Mio, T.; Ebiike, H.; Taka, N.; Aoki, Y.; Ishii, N. The Fibroblast Growth Factor Receptor Genetic Status as a Potential Predictor of the Sensitivity to CH5183284/Debio 1347, a Novel Selective FGFR Inhibitor. Mol. Cancer Ther. 2014, 13, 2547-2558.

50. Lee, C. Y.; Ahn, S. J.; Cheon, C. H. Protodeboronation of ortho- and para-Phenol Boronic Acids and Application to ortho and meta Functionalization of Phenols Using Boronic Acids as Blocking and Directing Groups. J. Org. Chem. 2013, 78, 12154-12160. 
https://www.thermofisher.com/us/en/home/industrial/pharma-biopharma/drug-discovery-

development/target-and-lead-identification-and-validation/kinasebiology/kinase-activity-assays/z-

lyte.html (accessed 15/06/2021).

52. McBride, C. M.; Renhowe, P. A.; Heise, C.; Jansen, J. M.; Lapointe, G.; Ma, S.; Piñeda, R.; Vora, J.; Wiesmann, M.; Shafer, C. M. Design and structure-activity relationship of 3-benzimidazol-2yl-1H-indazoles as inhibitors of receptor tyrosine kinases. Bioorg. Med. Chem. Lett. 2006, 16, 35953599.

53. Yan, W.; Wang, X.; Dai, Y.; Zhao, B.; Yang, X.; Fan, J.; Gao, Y.; Meng, F.; Wang, Y.; Luo, C.; Ai, J.; Geng, M.; Duan, W. Discovery of 3-(5'-Substituted)-Benzimidazole-5-(1-(3,5dichloropyridin-4-yl)ethoxy)- $1 H$-indazoles as Potent Fibroblast Growth Factor Receptor Inhibitors: Design, Synthesis, and Biological Evaluation. J. Med. Chem. 2016, 59, 6690-6708.

54. Liu, J.; Peng, X.; Dai, Y.; Zhang, W.; Ren, S.; Ai, J.; Geng, M.; Li, Y. Design, synthesis and biological evaluation of novel FGFR inhibitors bearing an indazole scaffold. Org. Biomol. Chem. 2015, $13,7643-7654$.

55. Norman, R. A.; Schott, A. K.; Andrews, D. M.; Breed, J.; Foote, K. M.; Garner, A. P.; Ogg, D.; Orme, J. P.; Pink, J. H.; Roberts, K.; Rudge, D. A.; Thomas, A. P.; Leach, A. G. Protein-Ligand Crystal Structures Can Guide the Design of Selective Inhibitors of the FGFR Tyrosine Kinase. J. Med. Chem. 2012, 55, 5003-5012.

56. Klein, T.; Tucker, J.; Holdgate, G. A.; Norman, R. A.; Breeze, A. L. FGFR1 Kinase Inhibitors: Close Regioisomers Adopt Divergent Binding Modes and Display Distinct Biophysical Signatures. ACS Med. Chem. Lett. 2014, 5, 166-171.

57. Tucker, Julie A.; Klein, T.; Breed, J.; Breeze, Alexander L.; Overman, R.; Phillips, C.; Norman, Richard A. Structural Insights into FGFR Kinase Isoform Selectivity: Diverse Binding Modes of AZD4547 and Ponatinib in Complex with FGFR1 and FGFR4. Structure. 2014, 22, 1764-1774.

58. Chae, Y. K.; Hong, F.; Vaklavas, C.; Cheng, H. H.; Hammerman, P.; Mitchell, E. P.; Zwiebel, J. A.; Ivy, S. P.; Gray, R. J.; Li, S.; McShane, L. M.; Rubinstein, L. V.; Patton, D.; Williams, P. M.; Hamilton, S. R.; Mansfield, A.; Conley, B. A.; Arteaga, C. L.; Harris, L. N.; O’Dwyer, P. J.; Chen, A. P.; Flaherty, K. T. Phase II Study of AZD4547 in Patients With Tumors Harboring Aberrations in the FGFR Pathway: Results From the NCI-MATCH Trial (EAY131) Subprotocol W. J. Clin. Oncol. 2020, 38, 2407-2417.

59. Guimarães, C. R. W.; Rai, B. K.; Munchhof, M. J.; Liu, S.; Wang, J.; Bhattacharya, S. K.; Buckbinder, L. Understanding the Impact of the P-loop Conformation on Kinase Selectivity. J. Chem. Inf. Model. 2011, 51, 1199-1204.

60. Hari, S. B.; Perera, B. G. K.; Ranjitkar, P.; Seeliger, M. A.; Maly, D. J. Conformation-selective inhibitors reveal differences in the activation and phosphate-binding loops of the tyrosine kinases Abl and Src. ACS Chem. Biol. 2013, 8, 2734-2743.

61. Miyake, M.; Ishii, M.; Koyama, N.; Kawashima, K.; Kodama, T.; Anai, S.; Fujimoto, K.; Hirao, Y.; Sugano, K. 1-tert-Butyl-3-[6-(3,5-dimethoxy-phenyl)-2-(4-diethylamino-butylamino)-pyrido[2,3d] pyrimidin-7-yl]-urea (PD173074), a Selective Tyrosine Kinase Inhibitor of Fibroblast Growth Factor Receptor-3 (FGFR3), Inhibits Cell Proliferation of Bladder Cancer Carrying the FGFR3 Gene Mutation along with Up-Regulation of $\mathrm{p} 27 / \mathrm{Kip} 1$ and $\mathrm{G}_{1} / \mathrm{G}_{0}$ Arrest. J. Pharmacol. Exp. Ther. 2010, 332, 795-802. 62. Morita, T.; Shinohara, N.; Honma, M.; Tokue, A. Establishment and characterization of a new cell-line from human bladder-cancer (JMSU1). Urol. Res. 1995, 23, 143-149.

63. Tomlinson, D. C.; Lamont, F. R.; Shnyder, S. D.; Knowles, M. A. Fibroblast Growth Factor Receptor 1 Promotes Proliferation and Survival via Activation of the Mitogen-Activated Protein Kinase Pathway in Bladder Cancer. Cancer Res. 2009, 69, 4613-4620.

64. Ethier, S. P.; Kokeny, K. E.; Ridings, J. W.; Dilts, C. A. erbB family receptor expression and growth regulation in a newly isolated human breast cancer cell line. Cancer Res. 1996, 56, 899-907.

65. Tannheimer, S. L.; Rehemtulla, A.; Ethier, S. P. Characterization of fibroblast growth factor receptor 2 overexpression in the human breast cancer cell line SUM-52PE. Breast Cancer Res. 2000, $2,311-320$.

66. Williams, R. D. Human urologic cancer cell-lines. Invest. Urol. 1980, 17, 359-363.

67. Winter, G.; Waterman, D. G.; Parkhurst, J. M.; Brewster, A. S.; Gildea, R. J.; Gerstel, M.; Fuentes-Montero, L.; Vollmar, M.; Michels-Clark, T.; Young, I. D.; Sauter, N. K.; Evans, G. DIALS: 
implementation and evaluation of a new integration package. Acta. Crystallogr. D. Struct. Biol. 2018, 74, 85-97.

68. Murshudov, G. N.; Skubák, P.; Lebedev, A. A.; Pannu, N. S.; Steiner, R. A.; Nicholls, R. A.; Winn, M. D.; Long, F.; Vagin, A. A. REFMAC5 for the refinement of macromolecular crystal structures. Acta. Crystallogr. D. Biol. Crystallogr. 2011, 67, 355-367.

69. Potterton, L.; Agirre, J.; Ballard, C.; Cowtan, K.; Dodson, E.; Evans, P. R.; Jenkins, H. T.; Keegan, R.; Krissinel, E.; Stevenson, K.; Lebedev, A.; McNicholas, S. J.; Nicholls, R. A.; Noble, M.; Pannu, N. S.; Roth, C.; Sheldrick, G.; Skubak, P.; Turkenburg, J.; Uski, V.; von Delft, F.; Waterman, D.; Wilson, K.; Winn, M.; Wojdyr, M. CCP4i2: the new graphical user interface to the CCP4 program suite. Acta. Crystallogr. D. Struct. Biol. 2018, 74, 68-84.

70. McCoy, A. J.; Grosse-Kunstleve, R. W.; Adams, P. D.; Winn, M. D.; Storoni, L. C.; Read, R. J. Phaser crystallographic software. J. Appl. Cryst. 2007, 40, 658-674.

71. Chen, H.; Ma, J.; Li, W.; Eliseenkova, A. V.; Xu, C.; Neubert, T. A.; Miller, W. T.; Mohammadi, M. A molecular brake in the kinase hinge region regulates the activity of receptor tyrosine kinases. Mol. Cell. 2007, 27, 717-730.

72. Emsley, P.; Lohkamp, B.; Scott, W. G.; Cowtan, K. Features and development of Coot. Acta. Crystallogr. D. Biol. Crystallogr. 2010, 66, 486-501.

73. Kovalevskiy, O.; Nicholls, R. A.; Long, F.; Carlon, A.; Murshudov, G. N. Overview of refinement procedures within REFMAC5: utilizing data from different sources. Acta. Crystallog. D. Struct Biol. 2018, 74, 215-227.

74. Lebedev, A. A.; Young, P.; Isupov, M. N.; Moroz, O. V.; Vagin, A. A.; Murshudov, G. N. JLigand: a graphical tool for the CCP4 template-restraint library. Acta. Crystallogr. D. Biol. Crystallogr. 2012, 68, 431-440.

75. Chen, V. B.; Arendall, W. B., 3rd; Headd, J. J.; Keedy, D. A.; Immormino, R. M.; Kapral, G. J.; Murray, L. W.; Richardson, J. S.; Richardson, D. C. MolProbity: all-atom structure validation for macromolecular crystallography. Acta. Crystallogr. D. Biol. Crystallogr. 2010, 66, 12-21.

76. Klein, T.; Vajpai, N.; Phillips, J. J.; Davies, G.; Holdgate, G. A.; Phillips, C.; Tucker, J. A.; Norman, R. A.; Scott, A. D.; Higazi, D. R.; Lowe, D.; Thompson, G. S.; Breeze, A. L. Structural and dynamic insights into the energetics of activation loop rearrangement in FGFR1 kinase. Nat. Commun. 2015, 6, 12 .

77. Harder, E.; Damm, W.; Maple, J.; Wu, C.; Reboul, M.; Xiang, J. Y.; Wang, L.; Lupyan, D.; Dahlgren, M. K.; Knight, J. L.; Kaus, J. W.; Cerutti, D. S.; Krilov, G.; Jorgensen, W. L.; Abel, R.; Friesner, R. A. OPLS3: A Force Field Providing Broad Coverage of Drug-like Small Molecules and Proteins. J. Chem. Theory Comput. 2016, 12, 281-296.

\section{Table of Contents graphic}

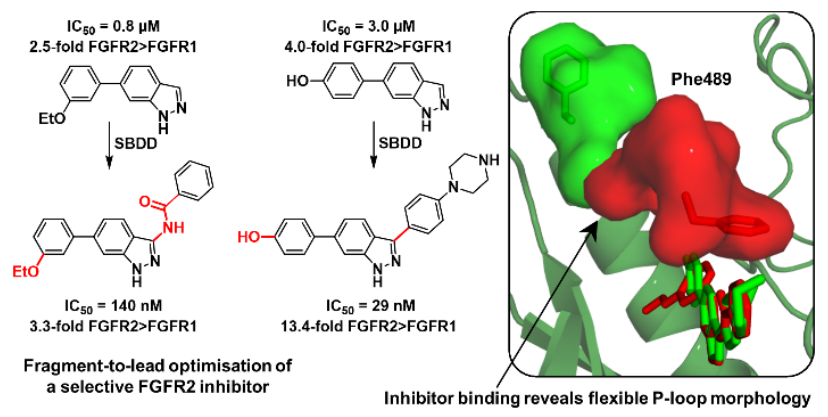

